Ankara Üniversitesi Türk Inkılâp Tarihi Enstitüsü Atatürk Yolu Dergisi

S 25-26, Mayts-Kasım 2000 s. 1-72

\title{
Çanakkale Savaşı Bibliyografyası
}

Doç. Dr. Oğuz AYTEPE*

18 Mart 1915 - 9 Ocak 1916 tarihleri arasında cereyan eden Çanakkale Savaşı, Türk askerinin inanç, azim, cesaret ve vatan sevgisinin ölümsüz bir destanıdır. Çanakkale Türk'ün gerektiğinde vatanı uğruna severek ölüme koşmasının ve Türk kahramanlığının anıtlaşmış örneğidir.

Çanakkale'de Türk askerinin, onu iyi sevk ve idare edebilen komutanlarla neler başarılabileceğini ortaya koyan Mustafa Kemal Atatürk bir yıldız gibi parlayarak tarih sahnesine çıkmıştır. Çanakkale Savaşları sonunda zamanın en modern silahları ile donatılmıs birleşik filo ve kara birlikleri, Türk askeri karşısında ağır bir yenilgiye uğramıs, Gelibolu yarımadasından geri çekilmek zorunda kalmıştır.

Çanakkale Savaşı; deniz, kara ve küçük hava harekâtı ile bir bütün teşkil etmektedir. Deniz ve kara savaşları birbirinden önemli, değerli sonuçlar doğuracak, kahramanlıkları sergileyecek niteliktedir. "Şark meselesinin" bir evresini oluşturan Çanakkale Savaşı Osmanlı İmparatorluğu'nu çökertmek, topraklarını paylaşmak amacını taşıyordu. Çanakkale Savaşı'nın doğurduğu olumlu sonuçlar, onun önemini gözler önüne sermektedir. Zafer kazanılmasaydı, bugün Türk Devleti muhtemel olarak var olamazdı.

20. yüzyıl başında arka arkaya gelen 1911 Trablusgarp ve 1912 Balkan Savaşları sonunda Osmanlı Devleti, Balkanlar'da, Doğu Trakya haricinde tüm topraklarını kaybetmiş, partiler arası mücadeleler nedeniyle idaresi neredeyse felç olmuş durumdaydı. Osmanlı Devleti İtilaf Devletlerinin kendisine karşı izlediği politikalar, son savaşlarda kaybedilen Osmanlı topraklarının geri alınması, Almanya'nın savaştan galip çıkacağı düşüncesi ile Almanya'ya yakınlaşmaya başladı. 2 Ağustos 1914 'te imzalanan gizli bir antlaşma ile İttifak Devletleri saflarına katılan Osmanlı Devleti, güvenliği açısından seferberlik ve silahlı tarafsızlığını ilan etti. Amiral Souchon komutasındaki Türk donanmasının Karadeniz'deki Rus limanlarını bombardıman etmesi üzerine bu olayı savaş nedeni sayan Ruslar Kafkasya'dan Türk sınırını geçerek savaşı başlattılar. Osmanlı Devleti de Rusya ve İngiltere'ye resmen savaş ilan etti.

Savaşın kısa sürede bitirilebilmesi, Rusya'nın Almanlara karşı savaşmasıyla mümkündü. Ancak müttefiklerinin yardımı olmaksızın Rusya

\footnotetext{
* Hacettepe Üniversitesi, Atatürk İlkeleri ve İnkılâp Tarihi Enstitüsü Öğretim Üyesi.
} 
bu gücü gösteremezdi. Rusya'daki ham maddelerin batıya ve batının mamül maddelerinin Rusya'ya ulaştırılması için en uygun yol İngiltere'yi Odessa'ya bağlayan Çanakkale ve İstanbul boğazları yolu idi. Ancak Çanakkale Cephesi'nin açılmasında birçok gerçek neden vardır: İstanbul'u ele geçirerek Osmanlı Devleti'nin yıkılmasını sağlamak ve harp dışı bırakmak; Türkleri barış yapmak zorunda bırakıp, Süveyş Kanalı ve Hindistan yolu üzerindeki Türk tehlikesini ve bütün cepheleri ortadan kaldırmak. Türklerin savaştan çekilmesiyle Almanya ve Avusturya-Macaristan'1 güneyden kuşatıp Avrupa'da tecrit etmek. Gizli yapılmış olan İstanbul Anlaşması ile Rusya'ya vereceklerini bildirdikleri Boğazlar bölgesini Ruya'dan önce ele geçirip barış masasına kuvvetli oturmak. Bulgaristan gibi harbe girmeye kararsız devletleri kendi taraflarına çekmek. Boğazları açarak Rusların kaynaklarından yararlanmak, ve ekonomisini düzeltmek. İslam alemine karșı Hilafetin prestij ve otoritesini kırmak. Türk ordusunun Sarıkamış Harekâtı'ndan etkilenen Rus Çarı Nikola'nın Türkiye'ye karşı karadan ve denizden cephe açılmasını istemesi.

İlk deniz savaşı 3 Kasım 1914'te İtilaf devletlerine mensup kruvazörlerin boğazın Anadolu ve Rumeli yakasındaki tabyaları bombalamasıyla başladı. İtilaf Devletlerinin Akdeniz Başkomutanı Amiral Karden'in yaptığı taarruz planına göre; Boğaz bir ay içinde geçilmiş olacaktı. 19 Şubat 1915 günü donanma taarruza geçti. İngiliz ve Fransız zırhlıları Çanakkale boğazına saldırdılar. Tabyalarımızdan buna şiddetli bir topçu ateşi ile karşılık verildi. Bu karşılığı beklemeyen düşman donanması Mondros'taki üssüne dönmek zorunda kaldı. İtilaf Devletleri 20, 25 Şubat ve 5 Mart günü yeniden saldırıya geçti karşılıklı ateşler gerek tabyalarımızda ve gerek düşman gemilerinde önemli hasar ve zarar meydana getirdi.

Müttefikler, sonuç alamadığı zorlamalardan sonra en son hücum planını uygulamak üzere 18 Mart 1915 'te üç tümen halinde saldırıya geçti. Ancak Amiral De Robeck Çanakkale'nin geçilemeyeceği gerçeğini kabul ederek donanmasını geri çekti.

İtilaf Devletleri son boğaz saldırısında ağır yenilgi almaları sonucu Gelibolu Yarımadasına karadan taarruz edilmesi karårı aldı ve 25 Nisan 1915 'te boğazın her iki sahiline taarruza geçti. Ancak kara savaşlarında da ağır yenilgiye uğrayan müttefikler tahliye kararı aldı ve 9 Ocak 1916'da Çanakkale'den çekilmek zorunda kaldılar.

Çanakkale Savaşı'nda İtilaf Devletleri, Türk kaynaklarına göre toplam 180.000 zayiat vermiștir. Türkler ise kara muharebelerinde 57.084 , deniz muharebelerinde 179.000 , şehit, yaralı, esir ve kayıp olmak üzere toplam 211.000 zayiat vermiştir. Bu savaşlarda bir çok okumuş ve aydın insanımız kaybedilmiş, bunun etkileri ilerki yıllarda kendini göstermiştir.

Çanakkale Savaşı sonunda Müttefik Filo'nun Boğazları geçerek İstanbul'u ele geçirme planları hayal olmuş, böylece hükümet çevrelerinde 
ortaya çıkan ve halka da yansıyan İstanbul'un elden çıkma korkusu silinmiştir. Osmanlı Devleti'ni savaş dışı bırakarak Almanya'yı kuşatmayı amaçlayan İtilaf Devletleri bu amaçlarına ulaşamamış ve savaş iki yıl daha uzamıştır. Çanakkale Boğazı'nın kapatılması, Rusya'yı müttefiklerinin silah ve cephane yardımından yoksun bırakmış, bu da Almanya'nın Doğu Cephesi harekâtını kolaylaştırmıştır. Bu durum Rusya'daki Çarlık rejimini zorda bırakmış, 1917 Rus Devrimi'ne varan iktisadi ve stratejik gelişmelere neden olmuştur. Çanakkale Savaşları, İngiliz ve Fransızların askeri ve siyasi prestijinin olumsuz etkilenmesine, İngiltere'nin denizlerdeki üstünlüğünün tartışılmaz olmadığının kanıtlanmasına neden olmuştur.

Büyük önder Atatürk, ulusun kaderinde üstün bir kumandan ve yetenekli bir asker olarak ilk kez Çanakkale'de kendisini kantllayacak, Çanakkale'deki başarıları O'nu Çankaya'ya götüren ve Atatürkleştiren ilk adım olacaktır.

İtilaf Devletlerinin denizden ve karadan yürüttüğü Çanakkale Boğazı'nı ele geçirme çabalarının taraflara çok ağır kayıplar verdirmesine karşın başarısızlıkla sonuçlanması, Osmanlı Devleti'nde içte ve dışta çok önemli gelişmelere neden olacaktır. Trablusgarp ve Balkan Savaşları yenilgileri ardından Çanakkale'de elde edilen askeri başarılar Türk ulusunun moralini düzeltecek, bu 1919'da başlatılacak Milli Mücadele'nin de ilk kıvılcımlarını oluşturacaktır.

Türk Tarihi içinde çok önemli bir yeri olan Çanakkale Savaşı ile ilgili olarak hazırladığımız Çanakkale Savaşı Bibliyografyası, Çanakkale Savaşı konusunda araştırma yapacakların yararlanmaları amacıyla konuyla ilgili dünyadaki, özellikle savaşa katılan devletlerin, arşivleri ve yayımları, başta Milli Kütüphane olmak üzere diğer kitaplıklar, elektronik kaynaklar incelenerek hazırlanmıştır.

\section{BİBLIYYOGRAFYA}

\section{MONOGRAFILER}

Abbott, G. F. Greece and the Allies, 1914-1922. London, Methuen, 1922.

Abisel, M. Arslan. Boğazlar Meselesi, Ankara, Çankaya Matbaası, 1945.

Adam, Colin Forbs. Life of Lord Lloyd. London, Macmillan, 1948.

Adamov, E. Die Europaischen Machte un die T, rkei wahrend de Weltkrieges: Konstantinople und die meerengen. Nach de Geheimdokumenten des ehem. Ministeriums $f_{3} r$ Auswatige Angelegenheiten. 4. C. Dresden, Carl Reissier, 1930-32.

Adam-Smith, Patsy. The Anzacs. London, Hamish Hamilton, 1978.

Adcock, A. St. John. Australasia Triumphant! With the Australians and New Zealanders in the Great War on Land and Sea. London, Simpkin, Marshal, Hamilton and Kent, 1916. 
Adil, Selahattin. Hayat Mücadeleleri. İstanbul, Zafer Matbaası, 1982.

Afşin, Zeki. Karanlıktan Aydınlı̆̆a. Ankara, 1958.

Ahmed, Emin. Turkey in the Great War, New Haven, Yale University Press,1930.

Ahmet İzzet Paşa [Furgaç]. Feryadım, C. I, İstanbul, Nehir Yayınları, 1992.

Ahmet Rıza Bey, Ahmet Rıza Bey'in Anıları, İstanbul, Arba Yayınları, 1983.

Aitken, Alexander, Gallipoli to the Somme. Recollections of a New Zealand Infantryman. London, Oxford University Press, 1963.

Akçelik, Rahmi. Ed. Before and After Gallipoli: A Collection of Australian and Turkish Writings. Melbourne, Australian-Turkish Friendship Society, 1986.

Aksoy, Ali. Yurduma Saldıranlara Ölüm, Çanakkale'de Yaratılan Türk Mucizesi ve Bunu Yaratan İsimsiz Kahramanlar. Çanakkale, Güven Basımevi, 1968.

Akşit İlhan, Çanakkale Savaşları Harp Sahaları ve Abideler. İstanbul, 1973.

Akşit, İlhan-Hayati Tezel, Mustafa Kemal ve Çanakkale 1915. İstanbul, 1982.

Alexander, H. M. On Two Fronts: Being the Adventures of an Indian Mule Corps in France and Gallipoli. London, William Heinemann, 1917.

Allanson, C. J. L. The Allonson Diary. N. P. : 6 th Queen Elizabethis Own Gurkha Rifles, 1977.

Allen, George H., et al. The Great War. 5 Vols, Philedelphia, George Barrieís Sons, 1915-21.

Allen, W. E . D., and Paul Muratoff. Caucasian Battlefields: A History of the Wars on the Turco-Caucasian Border, 1828-1921. Cambridge, Cambridge University Press, 1953

Alnıaçık, Hikmet. Çanakkale Muharebeleri 18 Mart Çanakkale Zaferi'nin 59'uncu Yıldönümünü Kutlarken. Ankara, Polatlı Top ve Füze Okulu, 1974.

Alp, Gündüz. Anafartalar Kahramanı. İstanbul, Maarif Matbaası ve Kütüphanesi. 1933.

Alpagut, Haydar. Büyük Harbin Deniz Cephesi. İstanbul, 1937.

Alpagut, Haydar. Büyük Harbin Türk Deniz Cephesi. İstanbul, Deniz Basımevi, 1937.

Alpar, Memduh. Ordu Donanma ve Hava Kuvvetlerinin Isstiraki ile Tamamen Renkli Muhteşem Film Çanakkale Aslanları. İstanbul, Seri İş Yayıncılık, 1965.

Altıntaş, Ahmet. Belgelerle Çanakkale Savaşları. Çanakkale 18 Mart Üniversitesi, Atatürk ve Çanakkale Savaşları'nı Araştırma Merkezi Yayınları, Çanakkale, 1997.

Altıntaş, Ahmet - Altıntaş, Zeynep. Çanakkale'de Bahriyelilerimiz. Çanakkale 18 Mart Üniversitesi, Atatürk ve Çanakkale Savaşları'nı Araştırma Merkezi Yayınları, Çanakkale, 1997.

65. R. E. A Short Record of the Service of the $65^{\text {th }}$ Field Company Royal Engineers. London, W. Heffer, 1920. 
Andrews, E. M. The Anzac Illusion: Anglo-Australian Relations During World War I. Cambridge, Cambridge University Press, 1993.

Andrews, Martin. Canonís Folly. London, Michael Joseph, 1974.

Andrews, Ted. Kivi Trooper: The Story of Queen Alexandraís Own. New Zealand, Wanganui Chronicle Co., 1967.

Anzac, An. Twelve Monts With the Australian Expeditionary Force. London, George Newnes, 1916.

Anzac Memorial: Soldiersí Stories of Gallipoli. London, Fisher Unwin, 1916.

The Anzac Book. London, Cassel and Company, 1916.

Arısoy, M. Sunullah. Mustafa Kemal Atatürk'ün Söyleyip Yazdıkları, 1. Kitap, Ankara, T.T.K. Basımevi, 1989.

Armaoğlu, Fahir. 20. Yüzyıl Siyasi Tarihi 1914-1980. Ankara, Tisa Matbası, 1984.

Armaoğlu, Fahir. Siyasi Tarih (1789-1960), Ankara, 1975.

Armstrong, H. C. Gray Wolf Mustafa Kemal: An Intimate Study of a Dictator. London, Arthur Barker, 1932.

Armstrong, H. C. Bozkurt. Kemal Atatürk'ün Yaşamı. Çev. Gül Çağalı Güven, İstanbul, Arba Yayınları, 1996.

Arthur, George. The Life of Lord Kitchener. 3 Vols. London, Mcmillan, 1920.

Artuç, İbrahim, 1915 Çanakkale Savaşı. İstanbul, Kastaş Yayınları, 1992.

Asal, Rıza Lebib. Deniz Ortasında Ölümü Yenen Adamlar. İstanbul, Kervan Kitapçılık, 1976.

Ashley, Maurice. Churchill As Historian. London, Martin Secker and Warburg, 1968.

Ashmead-Bartlett, Ellis. Ashmead-Bartlettís Despatches From the Dardenelles. London, George Newnes, 1916.

Ashmead-Bartlett, Ellis. Some of My Experiences in the Great War. London, George Newnes, 1918.

Ashmead-Bartlett, Ellis. Australians in Action: The Story of Gallipoli. Sydney, W. A. Gullick, 1915.

Ashmead-Bartlett, Ellis. The Uncensored Dardenelles. London, Hutchinson, 1928.

Ashmead-Bartlett, Ellis. Çanakkale Harekât-I Bahriyesine Dair İf̧̧aat. Çev., Rahmi, İstanbul, Matbaa-i Amire, 1331.

Ashmead-Bartlett, Ellis. Çanakkale Raporları. Çev. Rahmi, İstanbul, Matbaa-i Amire, 1331.

Ashworth, Tony. Trench Warfare, 1914-1918: The Live and Let Live System. New York, Holmes and Meier, 1980.

Aspinall-Oglander, Cecil. Roger Keyes: Being the Biography of Admiral of the Fleet Keyes of Zeebrugge and Dover. London, Hogarth, 1951. 
Aspinal-Oglander, C. F. History of the Great War Based on Offical Documents. Military Operations: Gallipoli, 2 Vols. London, William Heinemann, 1929-32.

Aspinal-Oglander, C. F. Büyük Harbin Tarihi. Çanakkale, Gelibolu Askeri Harekâtı, C., I. (Çev. Tahir Tunay), İstanbul, Askeri Matbaa,1939.

Aspinal-Oglander, C. F. Büyük Harbin Tarihi. Çanakkale, Gelibolu Askeri Harekâtı, C., II. (Çev. M.Hulusi), İstanbul, Askeri Matbaa, 1940.

Asprey, R. B. “Gallipoli”, Marine Corps Gazette. 38 (October 1954) : 57-65.

Atatürk, Moustafa Kemal. Souvenirs du Gazi Mustafa Kemal Pacha, version française remaniée d'apres l'original turc. Çev. Jean Deny. Paris, Paul Geuthner, 1927.

Atatürk, Mustafa Kemal. Arıburnu Muharebeleri Raporu. Yayınlayan, Uluğ İğdemir. Ankara, 1990.

Atatürk, Mustafa Kemal. The Story of Gallipoli As Recounted By Mustafa Kemal. İstanbul, 1990.

Atkinson, C. T. The History of the Royal Hampshire Regiment. 2. Vols, Winchester, Regimental Head Quarters, 1952.

Atkinson, C. T. The History of the South Wales Borderers, 1914-1918. London, Medici Society, 1931.

Atkinson, C. T. The Queenís Own Royal West Kent Regiment, 1914-1919. London, Simpkin, Marshall, Hamilton, Kent., 1924.

Atsı, Nihal. Çanakkale'ye Yürüyüş. İstanbul, 1933.

Austin, Ronald J. As Rough as Bags: The History of the 6 th Batallion,1st A.I.F., 1914-1919. McCrae, Vic.: R. J. and S. P. Austin, 1992.

Austin, Tom. Dear Mother. Perth, St. George Books, 1990.

Avustralya Resmi Tarihinde Gelibolu/Çanakkale, Haz., Prof. Dr. Abdurrahman Güzel, Çanakkale, 1996.

Aydemir, Şevket Süreyya, Tek Adam, Mustafa Kemal, 1881-1919, C. II. İstanbul, 1974.

Aydemir, Șevket Süreyya. Makedonya'dan Ortaasya'ya Enver Paşa, 1908-1914, C. II. İstanbul, 1981.

Aydemir, Şevket Süreyya. Makedonya'dan Ortaasya'ya Enver Paşa, 1914-1922, C.III. İstanbul, 1978.

Babington, Anthony. For the Sake of Example: Capital Courts Martial, 1914-1920. New York, St. Martinís Press, 1983.

Bacon, R. H. The Life of Lord Fisher of Kilverstone: Admiral of the Fleet. 2. Vols. London, Hodder and Stoughton, 1929.

Bacon, Reginald and F. E. McMutrie. Modern Naval Strategy. London, Frederick Muller, 1940. 
Bagnal, Nigel. The Human Story. London, Woolrich Building Society, 1992.

Bagnal, N. T. "ANZAC”, Army Quarterly and Defense Journal, 87 (1963-64): 19296.

Baldwin, Hanson. World War I. New York, Harper and Row, 1962.

Ballard, C. R. Kitchener. London, George Newnes, 1936.

Banks, Arthur. A Military Atlas of the First World War. London, William Heinemann, 1975-1989.

Banoğlu, Niyazi Ahmet. Türk Basınında Çanakkale Günleri. İstanbul, Türk Basın Birliği Yayını, 1982.

Banoğlu, Niyazi Ahmet. 67. Yıl Dönümünde Çanakkale Zaferinin Altın Sayfaları. İstanbul, 1982.

Bargut, Şemsi. Birinci ve Íkinci Dünya Harplerinde Akdeniz, (Deniz Mecmuası İlavesi), İstanbul, Deniz Matbaası, 1946.

Barrow, George. The Life of General Sir Charles Carmichael Monro. London, Hutchinson, 1931.

Bastier, Jean. Pierre Drieu La Rochelle, Soldat de la grand guerre, 1914-1919. Paris, Al batros, 1989.

Bavin, W. G. Swindonís War Record. Swindon, John Drew, 1922.

Baycan, Nusret. Birinci Dünya Harbinde Türk Harbi, Çanakkale Cephesi, 25 Nisan Arıburnu Çıkarması, 27. Piyade Alayının Karşı Taarruzu Desteklemesi. Ankara, Genel Kurmay Bşk. Yayını, 1976.

Baycan, Nusret. Atatürk ve Askerlik Sanatı. Anakara, Genelkurmay Bşk. Yayını, 1985.

Baycan, Nusret. Atatürk'ün Nişan ve Madalyaları. Ankara, Genel Kurmay Basımevi, 1986.

Bayur, Yusuf, Hikmet, Türk İnkılâbı Tarihi, Savaşın Başından 1914-1915 Kışına Kadar. C., III., Kısım, I. Ankara, TTK, 1991.

Bayur, Yusuf Hikmet. Türk İnkılâbı tarihi. Çanakkale Vuruşmaları ve Onların Tepki ve Sonuçlart. C. III, Kısım, II, Ankara, TTK., 1991.

Beach, Hugh. The Murderous Responsibility: Gallipoli Memorial Lecture. London, Brasseyís, 1985.

Bean, C. E. W. The Official History of Australia in the War of 1914-1918 : The Story of Anzac. 2 Vols. Sydney, Angus and Robertson, 1921-1924.

Bean, C. E. W. Anzac to Amiens: A Shorter History of the Australian Fighting Services in the First World War. Canberra, Australian War Memorial, 1946.

Bean, C. E. W. Gallipoli Mission. Canberra, Australian War Memorial, 1948-1990.

Bean, C. E. W. Two Men I Knew: William Bridges and Brudenell White Founders of the A.I.F. Sydney, Angus and Robertson, 1957. 
Bean, C. E. W. Frontline Gallipoli: Diariers From the Trenches. Sydney, Allen and Unwin, 1990.

Bean, C. E. W. Gallipoli Correspondent: The Font Line Diary of C.E.W. Bean. Sydney, George Allen and Unwin, 1983.

Beaverbrook, Lord. Politicians and the War, 1914-1916. 2 Vols., London, Thornton, Butterworth, 1928-1932.

Becke, A. F. The Order of Battle of Division. London, His Majestyís Stationery Office, 1935-45.

Bedford, C. W. Legs Eleven: History of the $11^{\text {th }}$ Battalion A. I. F. Perth, Imperial, 1940.

Beesly, Patrick. Room 40: British Naval Intelligence 1914-18. New York, Harcourt Brace Jovanovich, 1982.

Beesly, Patrick. Very Special Admiral: The Life of Admiral J. H. Godfrey. London, Hamish Hamilton. 1980.

Behrend, Arthur. Make Me A Soldier: A Platoon Commander in Gallipoli. London, Eyre and Spottiswoode, 1961.

Belen, Fahri, Çanakkale Savaşı, İstanbul, Harp Akademileri Matbaası, 1935.

Belen, Fahri. Birinci Cihan Harbinde Türk Harbi 1914 Yılı Harekâtı. Ankara, 1964.

Belen, Fahri. Birinci Cihan Harbinde Türk Harbi Çanakkale Cephesi, 25 Nisan Arıburnu Çıkarması, 27'nci Piyade Alayının Karşı Taarruzu: 19ncu Tümenin Bu Karşı Taarruzu Desteklemesi. Genelkurmay Harp Tarihi Yayınları, Ankara, 1976.

Bell-Davies, Richard. Sailor in the Air. London, Peter Davies, 1967.

Ben-Moshe,Tuvia. Churchill: Strategy and History. Hemel Hemstead, Harvester Weatshaft, 1992.

Benn, Wedgewood. In the Side Shows. London, Hodder and Stoughton, 1919.

Bennett, Geoffrey. Naval Battles of the First World War. London, Batsford, 19681983.

Bennet, Jack. Gallipoli. Sydney, Angus and Robertson, 1981.

Benson, Irving. The Man With the Donkey: John Simpson Kirkpatrick, The Good Samaritan of Gallipoli. London, Hodder and Stoughton, 1965.

Besbelli, Saim, Çanakkale'de Türk Bahriyesi, İstanbul, 1959.

Bıçak, Hasan. Çanakkale Geçilemezdi. Marpres, 1992.

Bıyıklığlu, Tevfik, Çanakkale Muharebelerine Dair Konferans, İstanbul, 1950.

Bidou, Henry. Histoire de la Grande Guerre. Paris, Gallimard, 1936.

Bienaim, Vice-Admiral [Amedez Pierre Leonard ]. La Guerre Navale, 1914-1915: Fautes et Responsabilites. Paris, Jules Tallandier, 1920. 
Bigwood, George. The Lancashire Fighting Territorials. London, Country Life, [1916].

Bilbaşar, Saim. Çanakkale 1915, [İstanbul, 1971].

Bilbaşar, Seyhan. Çanakkale 1915. İstanbul, Apa-Ofset Basımevi, 1972.

Bilge, Sinan. Çanakkale Savaşları 1915-1916. İstanbul, Cin Matbaası 1995.

Binark, İsmail. Türk Sefer ve Zaferleri Bibliyografyası. Ankara, 1969.

1915'de Çanakkale'de Türk. Haz., Türkiye Cumhuriyeti Milli Müdafaa Vekâleti Erkânı Harbiye Riyaseti Harp Dairesi Başkanlığı, İstanbul, Deniz Basımevi, 1957.

Birdwood, William. Khaki and Gown: An Autobiography. London, Ward, Lock, 1941.

Birinci Dünya Harbi'nde Lojistik Faaliyetler ve Lojistik. C. X. Ankara, Gnkur. Basımevi, 1985.

Birinci Dünya Harbi'nde Türk Harbi Çanakkale Cephesi. II. C., Çanakkale Cephesi 2. Kısım, Haz., Remzi Yiğitgüden, Ankara, Genkur. Bşk. Harp Tarihi Yayınları, 1978.

Birinci Dünya Harbi'nde Türk Harbi. V. Cilt, Çanakkale Cephesi Harekâtı, I. Kitap (Haziran 1914-25 Nisan 1915), Ankara, Genkur. Bşk. Harp Tarihi Yayınları, 1993.

Birinci Dünya Harbi'nde Türk Harbi. V. Cilt, Çanakkale Cephesi. 2. Kitap. Anfibi Harekâtı. Ankara, Genkur. Bşk. Harp Tarihi Yayınları, 1978.

Birinci Dünya Harbi'nde Türk Harbi. V. Cilt. 3. Kitap. Çanakkale Cephesi Harekâtı. (Haziran 1915-Ocak 1916), Haz. İrfan Teksüt- Necati Köse, Ankara, Genkur. Bşk. Harp Tarihi Yayınları, 1980.

Birinci Dünya Harbi'nde Türk Harbi. V. Cilt, Çanakkale Cephesi Harekâtı. 1, 2 ve 3. Kitapların Özetlenmiş Tarihi. (Haziran 1914-9 Ocak 1916), Ankara, Genkur. Bşk. Harp Tarihi Yayınları, 1997.

Birinci Dünya Harbi'nde Türk Harbi. Deniz Harekatı. VIII. Cilt, Ankara, Genkur. Bşk. Harp Tarihi Yayınları, 1976.

Birinci Dünya Savaşı Ansiklopedisi. 7. C., İstanbul, Yener Yayınları, 1976.

Birkenhead, Earl of. Churchill, 1874-1922. London, Harrap, 1989.

Bishop, Edward. Better to Die: The Story of the Gurkhas. London, New English Library, 1976.

Blake, George. The Path of Glory. London, Constable, 1929.

Blumberg, H. E. Britain's Sea Soldiers: A Record of the Royal Marines During The War. Devenport, Swiss and Co., 1927.

Blythe, Ronald. Akenfield. Hatmondsworth: Allen Lane, The Penguin Press, 1969.

Bond, Brian. The First World War. 12 Vols, The New Cambridge Modern History. Cambridge Cambridge University Press, 1968. 
Borak, Sadi. Atatürk'ün Özel Mektupları. 2.bs., İstanbul, Varlık Basımevi, 1970.

Bosquet, Fernand. Face aux Balkans, 1914-1918. Albi, Imprimerie cooperative, 1939.

Bourne, J.M., Britain and The Great War 1914-1918. London,1994.

Bowes, Joseph. The Anzac War Trail. London, Milford, 1917.

Bowyer, Chaz. For Valour: The Air VCs. London, Grub Street Aviation Classics/ Distributed By Hills Book Distributors of Cincinnati, 1992.

Boyle, R. C. A Record of the West Somerset Yeomanry, 1914-19. London, St. Catherine Press, 1922.

Boz, Ekrem. Adım Adım Çanakkale Savaş Alanları. Çanakkale, 1993.

Brereton, C. B. Tales of Three Campaigns. London, Selwyn and Blount, 1927.

Bridges, R. The Immortal Dawn: The Australians at Gallipoli. London, Hodder and Stoughton, 1917.

Bridges, T. C. On Land and Sea at the Dardenelles. London, Collins, 1915.

Broad, Lewis. Winston Churchill. London, Hutchinson, 1941.

Broadbent, Harvey. The Boys Who Came Home: Recollections of Gallipoli. Crowsnest, N. S. W.: Australian Broadcasting Corporation, 1990.

Brock, Michael, and Eleanor Brock, eds. H.H. Asquith, Letters to Venetia Stanley. Oxford, Oxford University Press, 1982.

Brock, Ray. Ghost on Horseback: Incredible Atatürk. New York, Duell Sloan and Pearce, 1954.

Brodie, C. G. Forlorn Hope 1915: The Submarine Passage of the Daedenelles. London, Frederick Books/W. J. Bryce, 1956.

Broinowski, L., (ed.), Tasmaniaís War Record, 1914-1918. Hobart, Walch, 1921.

Brown, Malcom. The Imperial War Museum Book of the First World War: A Great Conflict Recalled in Previously Unpulished Letters, Diaries and Memoirs. London, Sidgwick and Jackson, 1991.

Brownrigg, Douglas. Unexpected: A Book of Memoirs. London, Hutchinson (t.y).

Bruce, Anthony. An Illustrated Companion to the First World War. London, Michael Joseph, 1988.

Brutose Mulmann. Çanakkale Muharebesi. (Çev. Halil Kemal), İstanbul, Askeri Matbaa, 1927.

Bryant, G. Where the Prize is Highest. London, Collins, 1972.

Bubnov, A. V Tsarkoy Stavske. [Çar'ın Karargahında], New York, Chekov Publishing House of the East Europen Fund, 1955.

Buchan, John. History of the Royal Scots Fusiliers, 1678-1918. London, Thomas Nelson, 1925. 
Buchan, John. Nelsonís History of War. 24 Vols. London, Thomas Nelson, 19151919.

Buchanan, George. My Mission to Russia. 2 Vols., London, 1923.

Buley, E. C. Glorious Deeds of Australians in the Great War. London, Andrew Melrose, 1915.

Bulut, Ayşe-Yazan, Nihal-Kâhya, Rahmi, Türk'ün Şeref Destanı Çanakkale Savaşları, İstanbul, Tercüman Gazetesi, 1986.

Burçak, Rıfkı Salim, Siyasi Tarih, Ankara,1978.

Burhanettin, İzzetin. Türk Cepheleri, Çanakkale Notları. İstanbul, 1929.

Burhanettin, İzettin. Harbi Umumi'de Çanakkale Muhaberat-ı Bahriyesi. İstanbul, Erkânı Harbiye Mektebi Matbaası, 1936.

Burness, Peter. The Nek. Kenthurst, Kangaroo Press, 1996.

Burrows, John W. The Essex Regiment. 5 Vols, Southend-0n-Sea, John H. Burrows, $(\mathrm{t}-\mathrm{y})$.

Burton, O. E. The Silent Division: New Zealanders at the Front, 1914-1919. Sydney, Angus and Robertson, 1935.

Burton, Ormond Edward. The Auckland Regiment: Being an Account of the Doing on Active Service of the Firs, Second and Third Battalions of the Auckland Regiment. Auckland, Whitcombe and Tombs, 1922.

Bush, Eric W. Gallipoli, London, Allen and Unwin, 1975.

Bush, Eric W. Bless Our Ship. London, Allen and Unwin, 1958.

Butler, A. G. The Gallipoli Campaign. Vol. 1, Part 1, The Australian, Army Medical Services in the War of 1914-1918. Melbourne: Australian War Memorial, 1930.

Bütün Yönleri İle Çanakkale Savunmast. İstanbul, Kuleli Askeri Lisesi Komutanlı̆̆ı, 1973.

Büyük Harpte Çanakkale Seferi. İstanbul, Askeri Matbaa, 1928.

Büyüktuğrul, Afif, Büyük Atamız ve Türk Denizciliği, Ankara, 1969.

Büyüktuğrul Afif. Çanakkale Olayı. (İstiklal Harbinde Deniz Cephesi), İstanbul, 1969.

Büyüktuğrul, Afif. Osmanlı Deniz Harp Tarihi ve Cumhuriyet Donanması. C.IV. Deniz Basım Evi, 1984.

Byrne, A. E. Official History of the Otago Regiment, New Zealand Expeditionary Force in the Great War. Dunedin, J. Wilkie, (t.y).

C. [Viscount Cobham]. The Yeomanry Cavalry of Worcestershire, 1914-1922. Sourbridge Mark and Moody, 1926.

Callinan, Bernard. Sir John Monash. Carlton, Vic.: Melbourne University Press, 1981. 
Callwell, C. E. The Dardanelles, London, Constable, 1919 ; 1924.

Callwell, C. E. Experiences of a Dugout, 1914-1918. London, Constable, 1920.

Callwell, C. E. Field Marshal Sir Henry Wilson: His Life and Diaries. 2 Vols, London, Cassel, 1927.

Campaign des Dardanelles. (Çev., M. E. Larcher), Paris, Chiron, 1924.

Carcopino, Jeröme. Souvenirs de l'Armee d'Orient, 1915-1917. Paris: Hechette, 1970.

Carr, W. G. By Guess and by God. London: Hutchinson, 1930.

Carter, Violet Bonham. Winston Churchill: An Intimate Portrait. New York : Harcourt, Brace and World, 1965.

Cartier, Raymond, and Jean-Pierre Cartier. La premiére Guerre Mondiale. 2 Vols. Paris: Presses de la cité, 1982-84.

Cassar, George H. Asquith as War Leader. London: Hambledon Press, 1994.

Cassar, George H. The French and the Dardenelles: A Study of Failure in the Conduct of War. London, George Allen and Unvin, 1971.

Cassar, George H., Çanakkale ve Fransızlar, İstanbul, Milliyet Yayınları, 1974.

Cassar, George H. Kitchener: Architec of Victory. London, William Kimber, 1977.

Castle, Wilfred T. F. Grand Turk. London, Hutchinson, (t.y).

Cavil, H. W. Imperishable Anzacs: A Story of Australia's Famous First Brigade. Sydney , William Brooks, 1916.

Celalettin (Yzb). Kumkale Muharebatı. İstanbul, Erkânı Harbiye Külliyatı, 1336 .

Chack, Paul. Des Dardenelles aux Brumes du Nord. Paris, Les Editions de France, 1937.

Chack, Paul. Pavillion haut. Paris, Les Editions de France, 1929.

Chack, Paul, and Jean-Jacques Antier. Méditerranée. Vol. 2, Histoire maritime de la Première Guerre mondiale. Paris, France-Empire, 1969; 1992.

Chambers, Frank P. The War Behind the War, 1914-1918: A History of the Political and Civilian Fronts. New York, Harcourt Brace, 1939.

Chapman, Guy, ed. Vain Glory: A Miscellany of the Great War 1914-1918 WrittenBy Those Who Fought in İt on Each Side and On All Fronts. London, Cassel, $1937 ; 1968$.

Charles-Roux, Francois. L'expédition des Dardenelles au jour Paris, A. Colin, 1920.

Charmley, John. Churchill: The End of Glory. London, Hutchinson, 1993.

Chattaway, T. P. History of the $15^{\text {th }}$ Battalion, Australian Imperial Forces. Brisbane, W. Brooks, 1948.

Chatterton, E. Keble. Dardenelles Dilemma: The Story of the Naval Operations. London, Rich and Cowan., 1935. 
Churchill, Winston, The World Crisis, 5 Vols. London , 1923; 1929.

Cihan Harbinde Osmanlı Harekâtı Tarihçesi Çanakkale Muhaberatı Dersaadet, Matbaa-i Askeriye, 1338 (1922).

Cllinan, Bernard. Sir John Monash. Carlton, Vic.: Melbourne University Press, 1981.

Cobber, Lance Corporal. The ANZAC Pilgrimís Progress: Ballads of Australiaís Army. (Edited by , A. St. John Adcock), London, Simpkin, Marshall, Hamilton and Kent, (t.y).

Cochrane, Peter. Simpson and the Donkey: The Making of a Legend. Carlton, Vic.: Melbourne University Press, 1992.

Cohen, Eliot A., and John Gooch. Military Misfortunes: The Anatomy of Failure in War. New York, The Free Press, 1990.

Collet, H. B. The 28 $8^{\text {th }}$. A Record of War Sevice with the A.I.F., 1915-1919. Perth, N.P., 1922.

Collier, Basil. Brasshat: A Biography of Field-Marshal Sir Henry Wilson. London, Secker and Warburg, 1961.

Collins, Dale. Anzac Adventure: The Story of Gallipoli Told for Young Readers. Sydney, Angus and Robertson, 1959.

Colwin John, Fisher. Churchill and the Dardenelles, London, 1996.

Compton-Hall, Richard. Submarines and the War at Sea, 1914-1918. London, Macmillan, 1991.

Con, (Amiral), Çanakkale'nin Tahliyesi. (Çev. Hüsamettein) İstanbul, 1333 (1917).

Condliffe, J. B. Te Rangi Hiroa: The Life of Sir Peter Buck. Chiristchurch, Whitcombe and Tombs, 1971.

Conk, Cemil. Hatıraları, Balkan Harbi 1912-1913, Çanakkale Seferi 1915. Canlı Tarihler, İstanbul, Türkiye Basım Evi, 1947.

Conk, Cemil. Çanakkale Conk Bayırı Savaşları. Ankara, Erkân-1 Harbiye-i Umumiye Basım Evi, 1959.

Cooper, Bryan. The Tenth. (Irish) Division in Gallipoli. London, Herbert Jenkins, 1918; 1993.

Cooper, John Butler. Coo-oo-ee: A Tale of Bushmen from Australia to Anzac. London, Hodder and Stoughton, 1916.

Corbett, Julian and Henry Newbolt. History of the Great War Based on Official Documents Naval Operations. 5 Vols. London, His Majestyís Stationary Office, $1920 ; 31$.

Cowan, James. The Maorish in the Great War: A History of the New Zealand Native Contingent and Pioneer Batallion. Auckland, Whitcombe and Tombs, 1928. 
Cowland, W. S. Ed. Some Accounts of the $10^{\text {th }}$ and $12^{\text {th }}$ Batallions of the Hampshire Regiment 1914-1918. Winchester, Warren and Son, [1930].

Cowles, Virginia, Winston Churchill: The Era and the Man. New York, Harper and Brothers, 1953.

Cramm, Richard. The Firs Five Hundred: Being a Historical Sketch of the Military Operations of the Royal Newfoundland Regiment in Gallipoli on the Western Front. New York, Williams. (t.y).

Craven, Digger [As told to W. J. Blackledge]. Peninsula of Death. London, Sampson Low , Marston, 1937.

Creagh, O'Moore, and E. M. Humphris, eds. The $V C$ and $D S O .3$ Vols. London, Standart Art Book Co., (t.y).

Creighton, O. With the Twenty-Ninth Division in Gallipoli: A Chaplainis Experiences. London, Longman, Green, 1916.

Crisman, Herbert Henry. Naval Operations in the Mediterranean During the Great War 1914-1918. Stanford University , 1931. ( Doktora Tezi)

Crutchley, C. E., Ed. Machine Gunner, 1914-1918: Personal Experiences of the Machine Corps. Northampton, Mercury Press, 1973 ; 1975.

Cruttwell, C.R.M.F. A History of the Great War. Oxford, Oxford University Press, 1934.

Cruttwell, C.R.M.F. The Role of British Strategy in the Great War. Cambridge, Cambridge University Press, 1936.

Conk, Cemil, Çanakkale Conkbayırı Savaşları, Ankara, 1959.

Conk, Cemil. Canlı Tarihler, İstanbul, 1947.

Corbert, Sir Julian, History of the Great War Based on Offical Document: Naval Operations, II., London, 1921.

Corbert, Sir Julian, Harekât-ı Bahriye, (Çev., Haluk Saltıkgil), 1965.

Cunliffe, Marcus. The Royal Irish Fusiliers. London, Oxford University Press, 1952.

Cunningham of Hyndhope, Lord [Andrew Cunningham]. A Sailorís Odyssey. London, Hutchinson, 1951.

Curran, Tom. Across the Bar: the Story of Simpson. The Man With the Donkey. Yeronga, Ogmios Publications. 1994.

Currey, E. H. How We Kept the Sea. London, Thomas Nelson, (t.y).

Curtright, Lynn H. Muddle, Indecision and Setback: British Policy and the Balkan States: August 1914 to the Inception of the Dardenelles Campaign. Tessaloniki, Institute for Balkan Studies, 1986.

Çaka, Galip. 18 Mart 1915 Çanakkale Destanı. Adana, Zemin Matbaası, 1953.

Çamoğlu, Şemsettin, Çanakkale Boğazı ve Savaşları, İstanbul, Kurtuluş Matbaası, 1962. 
Çamoğlu, Şemsettin. 18 Mart 1915 Çanakkale Zaferi. [İstanbul],Güven Matbaası, 1953.

Çanakkale, (Çev. Rahmi), İstanbul, Matbaa-i Amire, 1331 (1915).

Çanakkale - 1915. (Haz., Hülya Yarar v.d), Ankara, Milli Savunma Bakanlığı, 1999.

Çanakkale 5-18 Mart 1331/1915 Yeni Mecmua'nın Fevkalade Nüshası, Hilâl Matbaas1, 1918.

Çanakkale, [Yeni Mecmua'nın Özel Sayısı'nda Neşredilen Çanakkale Savaşları Üzerine Değerlendirmeler İstanbul, 5/18 Mart 1331/1915], (Haz. Abdurrahman Güzel), Çanakkale, 1996.

Çanakkale. Çanakkale Zaferinin 75. Yılı. (Haz., Naşit Bora Aydoğan), VizeKırklareli, Sermet Marbaası, 1989.

Çanakkale Boğazı, Barış ve Düşündürdükleri Sempozyumu (17 Mart 1993): Çanakkale 18 Mart Üniversitesi, 17 Mart 1993.

Çanakkale Destanında En Önemli Gün. İstanbul, Hüsnü Tabiat Matbaası, 1961.

Çanakkale Geçilmez. Çankırı, Astsubay Hazırlama Okulu, 1989.

Çanakkale Harbinde Lağam Muharesine Dair Elde Edilen Tecarib. (Muller'den Çeviri), İstanbul, Matbaa-i Askeriye, 1332 (1916)

Çanakkale İçinde Vurdular Beni. (Derleyen. Aziz Kaylan), Tercüman Gazetesi, (t.y),

Çanakkale'de Kumkale Harekâtı. (t-y), ( y-y).

Çanakkale Kumkale Muharebesi. İstanbul, Askeri Matbaa, 1336 (1920).

Çanakkale ve Mehmetçik. (Yayınlayan. Türkiye Kemalistler Teşkilatı), İstanbul, Gün Matbaası, 1965.

Çanakkale Muharebatı Bahriyesi. İstanbul, 1336 (1920).

Çanakkale Muharebatı-Cihan Harbinde Osmanlı Harekâtı Tarihçesi. Cüz, I. İstanbul, 1922

Çanakkale Muharebeleri, Arıburnu ve Anafartalar Cephesi. (t.y), ( y.y).

Çanakkale Muharebeleri - Muharebe Sahaları Gezi Rehberi. (t.y), ( y.y).

Çanakkale Muharebeleri 75 nci Yıl Armağanı. Ankara, Genkur. Basımevi, 1990.

Çanakkale Muharebeleri Harp Tarihi Broşürü, Ankara, Genkur. Bşk., 1997.

Çanakkale Muharebeleri ve Atatürk (Sempozyumu), Ankara, K.K.K. Fakülte ve Yüksek Okullar Askeri Öğrenci Komutanlığı Atatürkçülük Çalışma Merkezi. 1987.

Çanakkale 18 Mart 1915 - 1950, Ankara, T.T.K. Basımevi, 1950.

Çanakkale Savaş Hatıraları Sergisi. (Yay. Kültür ve Turizm Bakanlı̆̆ı) Ankara, Doğuş Matbaası, 1965. 
“Çanakkale Savaşları'nın Askeri ve Siyasi Yönü” Sempozyumu Bildirileri.18 Mart 1986. (Derleyen, Mete Tunçoku), Ankara,1987.

Çanakkale Savaşları 1915-1916: 80. Yıldönümü. Gallipoli Campaign: 80th Anniversary, (Derleyen, Sinan Bilge), İstanbul, Cem Ofset, 1995.

Çanakkale Savaşları Sebep ve Sonuçları Uluslararası Sempozyumu, Çanakkale, (1417 Mart 1990), Ankara, T.T.K. Yayınları, 1993.

“Çanakkale Savaşları'nın Askeri ve Siyasi Yönü” Sempozyumu Bildirileri. Ankara, Orta Doğu Teknik Üniversitesi, 1987.

Çanakkale Seferi. İstanbul, 1337 (1921).

Çanakkale Tahkik Heyeti, Çanakkale Raporu. (Çev. Hüsamettin) İstanbul, 1333/ 1917.

Çanakkale Zaferi. Güçlü Çağ Özel Sayısı, (t.y), (y.y)

Çanakkale Zaferi. İstanbul, Harp Akademileri, 1981.

Çanakkale Zaferi'nin 51. Yıl Dönümü. (Yay. Milli Türk Talebe Birliği), İstanbul, Karadeniz Matbaası, 1966.

Çanakkale Zaferi'nin 80. Yıldönümü Özel Sayısı. Atatürk Araştırma Merkezi Dergisi, C.10 , S. 30 (Kasım 1994).

Çanakkale: Where the Heros Rest, (Haz., Temoçin Tulgar; English editor:Marnie Anderson, photos : Bekir Baki Aksu), Ankara, Ajans Türk Matbaacılık, 1995.

Çanakkale'de Türk 1915'de. İstanbul, Deniz Basımevi, 1967.

Çelebican, Tahsin, Çanakkale'de Nasıl Kazandık, İstanbul, Vakit Basımevi, 1937.

Çeliker, Fahri. Çanakkale ve Mustafa Kemal. Ankara, T.T.K. Yayınları, 1987.

Çetiner, Selahattin, Çanakkale Savaşları Üzerine Bir İnceleme, [Ankara, 2000]

Çobanoğlu, Nihat. Harb-i Umumi'de Seddülbahir, (Cenup Grubu Muhaberabtı). İstanbul, 1936.

Çoker, Avni. Çanakkale Şehitlerini Ziyaret Münasebetiyle. Ankara, Akın Matbaası, 1952.

Dağlarca, Fazıl Hüsnü. Çanakkale Destanı. İstanbul, Ekin Basımevi, 1965.

Dağlarca, Fazıl Hüsnü. Çanakkale Muharebesi. İstanbul, Kitap Yayınları, 1981.

Dane, Edmund. British Campaigns in the Nearer East, 1914-1918: From the Outbreak of War With Turkey to the Taking of Jarusalem. London, Hodder and Stoughton, 1917.

Daniel, David Scott. Cap of Honour: The Story of the Gloucestershire Regiment (The 28 th/61 th Foot) 1694-1975. London, White Lion, 1951.

Dannengiesser, Hans. The campaign in Gallipoli (Gallipoli, Bedeuting und Verlauf der Kampfe 1915) by Hans Dannen fiesser and Charles James Prior Ball. Hyperion, Hutchinson and co ltd., 1928. 
Dardenelles, The: An Epic Told in Picture: A Hundred Photographs, Many Taken Under Fire. London, Alfieri, 1916.

Dardenelles, The: Their Story and Their Significance in the Great War, by the Author of "The Real Kaiser." London, Andrew Melrose, 1915.

Dardanelles Commission, The. First Report and Supplement, 1917, and Final Report and Appendices, 1919. Cmd 8490, Cmd. 371.

Dardanelles Commission, The. Final Report and Appendix. London, (HMSO), 1921.

Darde, Fernand, Vigt Mois de Guerre a Bord du Croiseur ìJeanne-DíArc,î 9 Aout 1914- 12 Avril 1916. Paris, Librairie, Acedèmique, 1918.

Darlington, Henry. Letters From Helles. London, Longman, Green, 1936.

David, Robert P. F. Le Drame ignorè de l'Armèe d'Orient: Dardenelles, Serbie, Salonique, Athens. Paris, Plon,1927.

Davidson, George. The Incomparable $29^{\text {th }}$ and the "River Clyde", Aberdeen, James Gordon Bisset, [1919].

Davis, Shona. Having a Lively Time: Australians at Gallipoli: A Catalogue of Material Held in the Australian Manuscripts Collection, LaTrobe Library, State Library of Victoria. Melbourne, Council of the State Library of Victoria, 1990

Day, Henry C. An Army Chaplainís War Memoirs. London, Burns,Oates and Washbourne, 1937.

Delage, Edmond. La Tragédie des Dardenelles. Paris, Bernard Grasset, 1931.

Delage, Edmond. The Tragedy of the Dardenelles, London, 1932.

De Loghe. Sydney. The Straits Impregnable. London, John Murray, 1917.

Demirel, Kemal. Anafartaların Beş Günü 6-10 A ğustos 1915. (t.y), (y.y).

Denham, H. M. Dardenelles: A Midshipman's Diary, 1915-16. London, John Murray,1981.

Denton, Kit. Gallipoli Illustrated. Adeleaide, Rigby, 1981.

Denton, Kit. Gallipoli: One Long Grave. Sydney, Time Life Books in Association with John Ferguson. 1986.

Des Mayes. L'Expédition des Dardenelles, 1925.

Des Mayes. Çanakkale Seferi, (Çev., Burhanettin ) İstanbul, 1930.

De Robeck, Amiral. Çanakkale'de Ingiliz Ordusunun I Temmuz 1915 Tarihli Raporu. (Çev. Rahmi), İstanbul, 1331 (1915).

Dewar, K. G. B. The Navy From Within. London, Gollancz, 1939.

Deygas, F-J. L'armée d'Orient dans la Guerre Mondiale: Dardenelles, Grèce, Macédoine, Albanie, Serbie, Bulgarie, Constantinople, Danube, Hongrie, Romanie Russie. Paris, Payot, 1932. 
Dinning, Hector. By-ways on Service: Notes From an Australian Journal. London, Constable, 1918.

Djalaleddin Dey. The Battle of Kum Kale. İstanbul, Turkish war College, 1920.

Dontas, Domna. Greece and Turkey: The Regime of the Straits, Lemnos and Samotrace. Athens, G. C. Eleftheroudakis, 1987.

Drew, H. T. B. Ed. The War Effort of New Zealand: A Popular History of Minor Campaigns in Which New Zealanders Took Part; Services Not Fully Dealt With in the Campaign Volumes; The Work at the Bases. Auckland, Whitcombe and Tombs, 1923.

Dukakinzade, Feridun. Büyük Harp -Türk Cepheleri- Çanakkale Muharebesi. İstanbul, Harp Akademileri Basımevi, 1927.

Dunstan, K. No Brains at All. New York, Viking, 1990.

Dupuy, Trevor N., and Grace P. Hayes. The Military History of World War I: The Campaigns on the Turkish Fronts. New York , Franklin Watts, 1967.

Dutton, David. Britain and France in the Balkans in the First World War, New York, St. Martins Press, 1998.

Dvrvbek, John-Vemis, Rozalin. Çanakkale Tahliyesi. (Çev. Hüsamettin) İstanbul, Matbaa-I Amire, 1333 (1917).

Edmonds, James. A Short History of World War I. London, Oxford University Press, 1951.

Edwards, Kenneth. We Dive at Dawn. London, Rich and Cowan, 1939.

Ellison, Gerald. The Perils of Amateur Stratgy. London, Longman, 1926.

Enginün, İnci. Çanakkale Zaferi'nin Edebiyata Aksi. (Türklük Araştırma Dergisi, 1986 Ayrı Basım), İstanbul, 1987.

Erdin, Ali. Çanakkale Kahramanı Havranlı Koca Seyit. İzmir, Karınca Matbaacılık, 1969.

Eren, Ramazan Çanakkale Savaşlarının Mana ve Ehemmiyeti. İstanbul, 1998.

Ergüder, Orhan. Harp Tarihi. Ankara, Harp Okulu Basımevi, 1959.

Erikan, Celal. Çanakkale'de Türk Zaferi, Ankara Güzel Sanatlar Matbaası, 1964.

Erikan, Celal. Komutan Atatürk. Ankara, İş Bankası Kültür Yayınları, 1972.

Ermumcu, Oğuz. Çanakkale Destanı. Ankara, Gisfik-Stüdyo Basımevi, 1986.

Eryıldız, Selahattin. Çanakkale Muharebeleri. İstanbul, Sıralar Matbaası, 1969.

Ewing, John. The Royal Scots 1914-1919. 2 Vols. Edinburg, Oliver and Boyd, 1925.

Fahri, M. Çanakkale Muharebelerinden Çıkartma Hususunda Alınan Dersler. İstanbul Harp Akademisi Basım Evi, 1933.

Falls, Cyrill, The Great War, New York, Capricorn Books, 1959. 
Fellows, George, and Benson Freeman. Historical Records of the South Nottinghamshire Yeomanry, 1794-1924. Aldershot, Gale and Polden, 1928

Ferguson, D. History of the Cantenbury Regiment, N.Z.E.F., 1914-1918. Auckland, Whitcombe and Tombs, 1921

Feulle, Henri, Face aux Turcs: Gallipoli 1915. Paris, Payot 1934.

Fewster, Kevin, Vecihi Başarın, and Hatice Hürmüz Başarın. A Turkish Wiew of Gallipoli. Richmond, Hodja, (t.y).

Fifth Battalion Highland Light Infantry, 1914-1918. The Glasgow, Maclehause, Jackson and Co., (t.y).

Firkin, Peter. The Australians in Nine Wars: Waikato to Long Tan. Adelaide, Rigby, 1971.

Fisher, Admiral of the Fleet, Lord. Records. London, Hodder and Stoughton, 1919.

Fitzherbert, Margeret. The Man Who Was Greenmantle: A Biography of Aubry Herbert. London, John Murray, 1983.

Fortescue, Granville. Russia, the Balkans and the Dardenelles. London, Andrew Melrose, 1915.

Fortescue, Granville. What of the Dardenelles? London, Hodder and Stoughton, 1915.

Foster, H. C. At Antwerp and in the Dardenelles. London, Mills and Boon, 1918.

Foster, Janet and Julia Sheppard. British Archives: A Guide to Archive Resources in teh United Kingdom. 3. bs. New York, Stockton Press, 1995.

Foster, Simon. Hit the Beach !: Amphibious Warfare From the Plains of Abraham to San Carlos Water. London, Arms and Armour, 1995.

Fox, Frank. The Royal Inniskilling Fusiliers in the Wold War. London, Constable, 1928.

Frame, T. R. and G. J. Swindon. First in, Last out: The Navy at Gallipoli. Kenthurst, Kangaroo, Press, 1990.

France. Ministere de la Guerre, Etat-Major de L'Armee. Service Historique, Les Armées françaises dans la Grand Guerre. 11 Tomes, Paris, 1922-37.

Franch, David. British Strategy and War Aims. London, Allen and Unwin, 1986.

Fraser, Peter. Lord Esher. London, Hart-Davis MacGibbon, 1973.

Freeman, Benson. The Yeomanry of Devon, 1794-1927. Edited by Earl Fortescue, London St. Catherine Press, 1927.

French, David. British Strategy and War Aims. London, Allen and Unwin, 1986.

Froemgen, Hanns. Kemal Atatürk: A Biography. Çev.Kenneth Kirkness, New York, Hill man-Curl, 1937.

From Dartmouth to the Dardenelles: A Midsshipmanís Log. Edited by his Mother, London, William Heinemann, 1926. 
Fromkin, David. A Peace to the End All Peace: The Fall of the Ottaman Empire and the Modern Middle East. New York , Henry Holt, 1989.

Fromkin, David. Barışa Son Veren Barış, 1914-1922, Çev. Mehmet Harmancı, İstanbul, 1993.

Frothingham, Thomas G. The Naval History of the World War: Offensive Operations. 3 Vols. Cambridge, MA: Military History Society of Massachusetts, 1924-26, 1971.

Fry, Gavin. Nolan's Gallipoli. Adelaide, Rigby, 1983.

Fuat. Çanakkale'de İntepe Topçuları. Anadolu Türk Kütüphanesi, 1932.

Fuller, J. F. C. The Decisive Battles of the Western World. 3. Vols. London, Eyre and Spottiswoode, 1956.

Fyfe, Albert J. Understanding the Wold War. Vol. 37 of Series IX: History, Amarican University Studies. New York, Peter Lang, 1988.

Gallipoli. London, Batsford, 1965.

Gallipoli: der Kmapf um den Orient, von einem Offizier aus der Stabe des marshalls Liman von Sansers. Berlin, A. Scherl, 1916.

Gallislaw, John. Trenching at Gallipoli: A Personal Narrative of a Newfoundlander with the Ill-fated Dardenelles Expedition. New York , 1916. Century.

Gammage, Bill. The Broken Years: Australian Soldiers in the Great War. Canberra, Australian National University Press, 1974.

Gammage, Bill and David Williamson. The Story of Gallipoli. Ringwood, Penguin, 1981.

Gardemarin, Pseud. Dardeneli. 1915, (y.y).

Gasson, James. Travis, V.C. Wellington, A.H. and W Reed, 1966.

Gazi Mustafa Kemal Atatürk'ten Bize. (Haz., M. Sunullah Arısoy), C. I. İstanbul, Hürriyet Ofset A.Ş. 1987.

Gençcan, Mehmet İhsan Çanakkale Savaşlarından Menkıbeler. Ankara, Kültür Bakanlığı, 1990.

Gençcan, Mehmet İhsan. Çanakkale Savaşları ve Menkıbeler. Çanakkale. Bayrak Matbaası, 1994.

Gençcan, Mehmet İhsan Çanakkale Savaşlarında Altın Harfler. 8.bs., İstanbul Bayrak Matbaası, 1998.

Gençcan, Mehmet İhsan. Güneşin Doğuşu Mustafa Kemal Atatürk Savaşı Anlattyor. Çanakkale, 1998.

Gençcan, Mehmet İhsan. Çanakkale Savaşlarında Kahraman Çocuklar. Çanakkale, Bayrak Matbaası, 1994.

Germains, Victor W. The Truth About Lord Kitchener. London, John Lane, 1925. 
Germains, Victor Wallace. The Trgedy of Winston Churchill. London, Hurst and Blackett, 1931.

Gibbon, Frederick P. The 42 ${ }^{\text {nd }}$ (East Lancahire) Division, 1914-1918. London, Country Life, 1920.

Gibbons, T. With the 1/5 th Essex in the East. Colchester, Benham, 1921.

Gilbert, Martin, Winston S. Churchill, 1914-1916, Vol., III, London, 1975.

Gilbert, Martin. Atlas of World War I. 2. bs. New York, Oxford University Press, 1994.

Gilbert, Martin. The Challenge of War, 1914-1916. Vol. 3, Winston Churchill, Boston, Houghton Mifflin, 1971.

Gilbert, Martin. A Life. London, William Heinemann, 1991.

Gilbert, Martin. The First World War: A Complete History. London, Weidenfeld and Nicolson, 1994.

Gilliam, John Graham. Gallipoli Adventure. London, Frederick Muller, 1939.

Glliam, John Graham. Gallipoli Diary. London, George Allen and Unwin ltd., 19181989.

Gillon, Stair. The K.O.S.B. in the Great War. London, Thomas Nelson (t.y).

Gillon, Stair. The Story of the 29 th Division. London, Thomas Nelson, 1925.

Ginn, Paul. British Stratgy and Politics, 1914 to 1918. Oxford, Clarendon Press, 1965.

Giradoux, Jean. Carnet des dardenelles. Paris, Le B,elier, 1969.

Giraud, Victor. Histoire de la Grande Guerre. Paris, Hachette, 1919.

Godley, Alexander. Life of an Irish Soldier: Reminiscences of General Sir Alexander Godley. London, John Murray, 1939.

Gooch, John. The Plans of War: The General Staff and British Military Strategy. London, Routledge and Kegan Paul, 1974.

Gorlainov, Serge. Çanakkale ve İstanbul Boğazları. Devlet-i Osmaniye - Rusya Siyaseti. Çev. Macar İskender-Ali Reşad, İstanbul, Kanaat Matbaası, 1331.

Gottlieb, W. W. Studies in Secret Diplomacy During the First World War. London, 1957.

Görgülü, İsmet. Çanakkale Zaferi'nin Komutan Kadrosu. İstanbul, Harp Akademileri Yayını, 1990.

Görgülü, İsmet. Çanakkale Zaferi Üzerine Alman İddiaları. İstanbul, 1992.

Görgülü, İsmet. On Yıllık Harbin Kadrosu 1912-1922. Balkan-Birinci Dünya ve İstiklâl Harbi. Ankara, T.T.K. Basımevi, 1993.

Görgülü, İsmet. On Yıllık Harbin Kadrosu 1912-1922 Balkan-Birinci Dünya ve İstiklâl Harbi. Marmara Üniversitesi. 1990. (Doktora Tezi) 
Görür, Osman. Harb-i Umumi'de Çanakkale'de Golyat Zırhlısının Nasıl Battı̆̆ının İ̧̧Yüzü. İstanbul, Tecelli Basımevi, 1939.

Gövsa, İbrahim Alâettin. Çanakkale İzleri. (Anafartalar Müebbet Kahramanına). İstanbul, Türkiye Matbaası, 1932.

Göymen, İ. Birinci Dünya Harbi - Türk Hava Harekâtı. Ankara, Genel Kurmay Basımevi, 1969.

Grham, J. G. Gallipoli Diary. London, Allen Unwin, 1918.

Grant, Amy Gordon. Letters From Armegeddon: A Collection Made During Graeat War Boston, Houghton Mifflin, 1930.

Grant, I. Jacka, VC. Melbourne, Macmillian in association with the Australian WarMemorial, 1989.

Graves, P. P. The Question of the Straits. London, Ernest Benn, 1931.

Gray, Edwyn. The Killing Time. London, Seeley, Service, 1972.

Gray, Edwyn. The U-boat War, 1914-1918. London, Leo Cooper, 1994.

Gray, Edwyn. The Underwater War: Submarines 1914-1918. New York, Charles Scribnerís Sons, 1971.

Great Britain. Dardenelles Commission. First Report, C M D 8490. London, His Majestyis Stationery Office, 1917; Final Report of the Dardenelles Commission, C M D 371. London, His Majestyís Stationary Office, 1918.

Gretton, Peter. Former Naval Person: Winston Churchill and the Royal Navy. London, Cassell, 1968.

Grey, Jeffrey. A Military History of Australia. Cambridge, Cambridge University Press, 1990.

Grey of Fallodon, Viscount. Twenty-five Years, 1892-1916. New York, Frederick A. Stokes, 1925.

Grey, W. E. $2^{\text {nd }}$ City of London Regiment (Royal Fusiliers) in the Great War. London, Royal Fusiliers, 1929.

Grieve, W. Grant and Bernard Newman. Tunnellers: The Story of the Tunnelling Companies, Royal Engineers, During the World War. London, Herbert Jenkins, 1936.

Guedalla, Philip. Mr. Churchill: A Portrait. London, Hodder and Stoughton, 1941.

Guèpratte, P.-E. L'Expédition des Dardenelles, 1914-1915, Paris, Payot, 19935.

Guinn, Paul. British Strayegy and Politics, 1914 to 1918. Oxford, Clarendon Press, 1965.

Gülen, Nejat. Şanlı Bahriye. Türk Bahriyesinin İkiyüz Yıllık Tarihçesi, 1773-1973. İstanbul, Kastaş Yaınları, 2001.

Güneri, Münir. Kahraman Ordusu. (y.y), 1964.

Günesen, Fikret, Çanakkale Savaşları. İstanbul, Kastaş A.Ş. Yayınları, 1986. 
Güzel, Abdurrahman Türk Edebiyatında Çanakkale Zaferi, Çanakkale, Semiz Ofset, 1996.

Güzel, Abdurrahman. Avustralya Resmi Tarihinde Gelibolu/Çanakkale. Çanakkale, Çanakkale Üniversitesi, Atatürk ve Çanakkale Savaşlarını Araştırma Merkezi Yayınları. 1996.

Gwyn, Sandra. Tapestry of War: A Private View of Canadians in the Great War. Toronto, Harper Collins, 1992.

Halil Kemal. Çanakkale Muharebesi. İstanbul, 1927.

Halis, Çanakkale Raporu, İstanbul, Eser Matbaası, 1975.

Halpern, Paul G., Ed. The Keyes Papers, Vol. 1: 1914-1918. Vol.117, Publications of the Navy Records Society. London, Navy Records Society, 1975- 1979.

Halpern, Paul G. A Naval History of World War I. Annapolis, Naval Institute Press, 1994.

Halpern, Paul G. The Naval War in the Mediterranean, 1914-1918. Annapolis, Naval Institute Press, 1987.

Halpern, Paul G., Ed. The Royal Navy in the Mediterranean, 1915-1918. Vol. 126, Publications of the Navy Records Society. Aldershot, Temple Smith for Navy Records Society, 1987.

Hamilton, A. S. The City of London Yeomanry (Roughriders). London, Hamilton Press, 1936.

Hamilton, Ian. The Commander. Edited by Antony Farrar-Hockley, Londra, Hollis and Carter, 1957.

Hamilton, Ian. Gallipoli Diary. 2 Vols. London, Edward Arnold, 1920.

Hamilton, Ian. Ian Hamiltonís Final Despatches. London, George Newnes, 1916.

Hamilton, Ian. Listening for Drums. London, Faber and Faber, 1944.

Hamilton, Ian. Sir Ian Hamiltonís Despatches From the Dardenelles. London, George Newness, (t.y).

Hamilton, Ian B. M. The Happy Warrior: A life General Sir Ian Hamilton, London, Cassell, 1966.

Hammerton, John A., ed. The Great War: I Was There! 3 Vols. London, The Amalgamated Press, 1938-39.

Hankey, Maurice. The Supreme Command 1914-1918. 2 Vols. London, Allen and Unvin 1961.

Hanna, Henry. The Pals at Suvla Bay: Being the Record of "D" Company of the 7 th Dublin Fusiliers. Dublin, Ponsonby, 1917.

Harbi Umumide Çanakkale Anafartalar Grubu Muharebatı, İstanbul, Erkanı Harbiye Matbaası, 1920.

Harbi Umumide Çanakkale Muharebatı, İstanbul, Askeri matbaa, 1332 (1916). 
Harbi Umumide Çanakkale Muharebatı Bahriyesi. İstanbul, Askeri Matbaa, 1336 (1920).

Harbi Umumide Osmanlı Tarihi Harbi. Çanakkale Muharebatı (y.y), 1332 (1916).

Hargrave, John. At Suvla Bay: Notes and Sketches. London, Constable, 1916.

Hargrave, John. The Suvla Bay Landing. London, McDonald, 1964.

Harp Mıntıkaları Şehir ve Kasabaların İsgal, İstirdat ve Bonbardıman Tarihleri. Italyan, Balkan, Büyük Harp ve İstiklal Mücadelesinde Ankara, Genelkurmay Matbaası 1940.

Hatemi, Nilüfer. Mareşal Fevzi Çakmak ve Günlükleri. C. I., İstanbul, Yapı Kredi Yayınları 2002.

Hayri. Harbi Umumide Çanakkale Muharebatı Berriyesi, Anafartalar Grubu Muharebatı, İstanbul, Erkanı Harbiye Mektebi Matbaası, 1920.

Hayri Bey. The Battles of Anafarta. Istanbul, Turkish War College, 1920.

Haythornthwaite, Philip J. Gallipoli 1915. London, Osprey, 1991.

Hazelhurst, Cameron. Politicians at War, July 1914 to May 1915. New York, Knopf, 1971.

Head,Charies Ostavius. A Glance at Gallipoli. London, Eyre And Spottiswoode, 1931.

Heichen, Walter. Im Kampf um die Dardenellen, Erzahlung aus dem Weltkrieg Berlin, Mars-Verlag C. Swinna, 1916.

Herbert, A. P. Secret Battle. London, Methuen, 1919.

Herman, Gerald. The Pivotal Conflict: A Comprehensive Chronology of the First World War, 1914-1919. New York, Greenwood Press, 1992.

Herman, Gerhard. Die Dardenellen. Leipzig, W. Goldmann, 1936.

Hersing, Otto. U-21 rettet die Dardenellen. Amalthea Verlag, 1932.

Hezlet, Arthur. The Submarine and Sea Power. London, Peter Davies, 1967.

Hickley, Michael, Gallipoli, London, John Murray, 1995.

Higgins, Trumbull. Winston Churchill and the Dardenelles: A Dialog in Ends and Means. London, Collier-McMillan, 1963.

Higham, Robin. Ed. A Guide to the Sources of British Military History. Berkeley, University of California Press, 1971.

Hill, A. J. Chauvel of the Light Horse: A Biography of General Sir Harry Chauvel. Melbourne University Press, 1978.

Historique des troupes coloniales pendant la guerre 1914-1918 (fronts extÈrieurs). Paris, Charles-Lavazuelle, 1931.

History of the Dorsetshire Regiment, 1914-1919. Dorchester, Henry Ling, 1933.

History of the 5th Royal Gurkha Rifles. Aldershot, Gale and Polden, 1929. 
History of the Old 2/4 ${ }^{\text {th }}$ (City of London) Batallion the London Regiment Royal Fusiliers. London, The Westminster Press, 1919.

Hodges, Arthur. Lord Kitchener. London, Thornton Butterworth, 1936.

Hoehling, A. A. The Great War at Sea. London, Barker, 1965-1995.

Hogue, Oliver. Trooper Bluegum at the Dardenelles. London, Andrew Melrose, 1916.

Holmes, Jessie. Pilgrimage to Gallipoli. London, Alexanser-Ousely.(t.y).

Holmes, Richard. The Little Field-Marshal: Sir John French. London, Jonathan Cape, 1981.

Holzhausen, Rudolf, Birinci Dünya Harbinde Almanya'nın Türkiye'ye Sağladığı Hava Desteği ve Çanakkale Havacıları. (Çev.Fahri Çeliker), Ankara, 1982.

Hoover, Karl D. "Commander Otto Hersing and the Dardenelles Cruise of S.M.U.21" American Neptune, 36 (1976): 33-44.

Horn, Daniel, Ed. War, Mutiny and Revolution in the German Navy: The World War Diary of Seaman Richard Stumpf. New Brumswick, Rutgers University Press, 1967.

Horne, Charles F., Ed. Source Records of the Great War. N.P., National Alumni, 1923.

Hough, Richard. First Sea Lord: An Authorized Biography of Admiral Lord Fisher. London, George Allen and Unvin, 1969.

Hough, Richard. Admiral of the Fleet: The Life of John Fisher. New York, McMillan, 1970.

Hough, Richard. Former Naval Person: Churchill and the War at Sea. London, Weidenfeld And Nicolson, 1985.

Hough, Richard. The Great War at Sea, 1914-1918. Oxford, Oxford University Press, 1983.

Hoyt, Edwin P. Disaster at the Dardenelles, 1915. London, Arthur Barker, 1976.

Hughes, W. M. The Splendid Edventure: A Review of Empire Relations Within and Without the Commonwealth of Britannic Nations. Toronto, Doubleday, Doran and Gundy, (t.y).

Hunt, Barry and Adrian Preston.War Aims and Strategic Policy in the Great War. London Croom Helm, 1977.

Hunter-Weston. "War and Peace at the Dardenelles." The Army Quarterly. 3 (192122): $70-76$.

Hurst, Gerald B. With Manchesters in the East. London, Longman, 1918.

Hutcheson, John A., Jr. Fom Constantinople to Coalition: British Press Reaction to the Dardenelles Campaign and the Fall of the Liberal Government. University of North Carolina, 1968. (Yüksek Lisans Tezi). 
Hüsamettin. Çanakkaleínin Tahliyesi, İstanbul, Matbaa-i Amire, 1333.

Hüsamettin (Çev.). Çanakkale Raporu. İstanbul, Matbaa-i Amire, 1333.

Hyd, Robin. Passport to Hell: The Story of James Douglas Stark, Bomber. Auckland Auckland University, 1986.

Idriess, Ion L. The Desert Column. Sydney, Angus and Robertson, 1932.

Ilgar, İhsan. Çanakkale 1915. İstanbul, Baha Matbaası, 1969.

Ilgar, İhsan, Çanakkale Savaşları 1915, Ankara, Yonca Matbaası, 1982.

Imperial War Museum. Department of Sound Recordings. Gallipoli: Oral History Recordings. London, Imperial War Museum Department of Sound Recording, 1994.

Ingle, Judith A. From Duntroom to the Dardenelles: A Biography of Lieutenant William Dawkins: Including His Diaries and Selected Letters. Canberra, J. Ingle, 1995.

Inglis, K.S. C.E.W. Bean: Australian Historian. St. Lucia, University of Queensland Press 1970.

Işık, Hüseyin, Çanakkale ve İstiklâl Savaşında Türk Jandarması. Ankara, Jandarma Genel Komutanlığı, 1974.

Işık, Hüseyin. Şehitlerimiz ve Gazilerimiz. (Çanakkale Savaşı ile Galiçya Cephesinde Şehit Olan ve Yaralanan Jandarma Subaylarının Biyografisi). Ankara, Jandarma Genel Komutanlığı, 1994.

İğdemir, Uluğ, Atatürk ve Anzaklar, Atatürk And The Anzacs, Ankara, T.T.K. Basımevi 1978.

İnönü, İsmet, Hatıralar, (Haz., Sabahattin Selek) , I. Kitap, İstanbul, 1985.

İrdesel, Mehmet. Çanakkale Savaşları ve Harp Sahaları Rehberi. İstanbul, Baha Matbası, 1973.

İrdesel, Mehmet. Gelibolu ve yöresi tarihi: Geliboluyu tanıyalım. Çanakkale tarihi, Pirireis: Çanakkale savaşları ve Milli Park, Troya-Assos ve tüm eski kentler tarihi. Gelibolu, Geltur Ajans, 1994.

İzzettin, Harb-i Umumide Çanakkale Muharebe-i Berriyesi. 1336.

İzettin, Çanakkale Arıburnu Muharebatı. İstanbul, 1336.

İzettin, Çanakkale Arıburnu Muharebatı. İstanbul, 1336.

İzzettin, Burhanettin. Çanakkale Muharebatı Hatıratından 12 Nisan Günü. İstanbul, Matbaa-i Amire, 1336.

İzzettin, Burhanettin. Çanakkale Muharebatı (12-14-18 Nisan Muharebatı), İstanbul, Askeri Matbaa, 1336.

İzzettin, Burhanettin. Harbi Umumide Çanakkale Muharebatı Berriyesi, Arıburnu Şimal Grubu Muharebatı. İstanbul, Erkânı Harbiye Mektebi Matbaası, 1336.

Jabotinsky, V. Turkey and the War. London, Fisher Unwin, 1917. 
Jack, Ernest, The Rising Crescent. Turkey Yesterday, Today, and Tomorrow. New York, Farrar and Rinehart, 1944.

Jackson, William and Lord Bramal. The Chiefs: The Story of the United Kingdom Chiefs of Staff. London, Brassey's, 1992.

James, Robert Rhodes, Gallipoli, London, Batsford, 1965-1989.

James, Robert Rhodes, Gelibolu Harekâtı, (Çev., V. Haluk Saltıkgil), İstanbul, 1965.

James, Robert Rhodes. Çanakkale Savaşı. 20. Yüzyıl Tarihi, 1950.

James, Robert Rhodes. Churchill: A Study in Failure. New York, World Publishing, 1970.

James, William. The Eyes of the Navy: A Biographical Study of Admiral Sir Reginald Hall. London, Methuen, 1955.

James, William. A Great Seaman: The Life of Admiral of the Fleet Sir Henry F. Oliver. London, H.F. and G. Witherby, 1956.

Jameson, William. The Fleet That Jack Built: Nine Men Who Made a Modern Navy. London, Rupert Hart-Davis, 1962.

Jameson, William. Submariners V.C. London, Peter Davies, 1962.

Jeans, T. T. Reminiscenc of a Naval Surgeon. London, Sampson Low, Marston, [1927].

Jerrold, Douglas. Georgian Adventure. London, Coolins, 1937.

Jerrold, Douglas. The Hwke Battalion: Some Personal Records of Four Years. London, Ernest Benn, 1925.

Jerrold, Douglas. The Royal Naval Division. London, Hutchinson, 1923.

Joe. Uncensored Letters From Dardenelles . London, William Heineman, 1916.

Joffre, Joseph J. C. Personal Memoirs. 2 Vols., Çev., Bentley Mott, New York, Harper, 1932.

Johnson, R. M. $29^{\text {th }}$ Divisional Artillery War Record and Honours Book, 1915-1918. Woolwich, Royal Artillery Institution, 1921.

Johnston, Tom. Orange, Green and Khaki: The Story of Irish Regiments in the Great War, 1914-1918. Dublin, Gill and Macmillan, 1992.

Jones, Denis. The Diary of a Padre at Suvla Bay. Manchester, Faith Press, (t.y).

Jones, Jonah. Gallipoli Diary. Chester Springs, Dufour Editions, 1989.

Jose, Arthur. The Royal Australian Navy, 1914-1918. Vol. 9, The Official History of Australia in the War of 1914-1918. Melbourne, Australian War Memorial, 19281987.

Jourdain, H.F.N., and Edward Fraser. The Cannaught Rangers. 3 Vols. London, Royal United Service Institution, 1928.

Juvenis. Suvla Bay and After. London, Hodder and Stoughton, 1916. 
Kadri. Çanakkale Savaşları Tarihi, İstanbul, 1935- 1960.

Kahramanlık Destanları. İstanbul, Genel Kurmay X Şube ,Askeri Matbaa, 1937.

Kannengiesser, Hans von. Bedeutung und verlauf der Kampfe. Berlin, Schlieffen Verlag, 1927.

Kannengiesser, Hans von. The Campaign in Gallipoli. (Çev., C.J.P. Ball) London, Hutchinson, 1928.

Kanlı Sırt Günlüğü: Mehmet Fasih Bey'in Çanakkale Anıları. (Haz., Murat Çulcu), İstanbul, Arba Yayınları, 1997.

Karabekir, Kazım. Cihan Harbine Neden Girdik, Nasıl Girdik, Nasıl İdare Ettik. C. II. İstanbul, 1937.

Karal, E. Ziya, Büyük Harpte Çanakkale, CHP Yayınları, İstanbul, 1938.

Karatay, Baha Vefa, Mehmetçik ve Anzaklar. Ankara, Türkiye İş Bankası Yayınları, 1987.

Kayabalı, İsmail-Cemender Arslanoğlu. Çanakkale Zaferi 1915. Ankara, 1975.

Kayalı, İsmail, Cemender Arslanoğlu Çanakkale Zaferi 1915. Ankara, 1975.

Kearsky, A.H.C. Notes and Comments on the Dardenelles Campaign. Aldershot, Gale and Polden , 1934.

Kedourie, Elie. England and the Middle East, The destruction of the Ottoman Empire: 1914-1921 London, Bowes and Bowes, 1956.

Keyes, Sir Roger. Des bancs de Flandre aux Dardenelles. Paris, 1936.

Keyes, Roger. The Fight for Gallipoli. London, Eyre and Spottiswoode, 1941.

Keyes, Roger. Naval Memoirs of the Fleet Sir Roger Keyes. 2 Vols. London, Thornton Buttrworth, 1934.

King, Jere C. Ed. The First World War. Documentary History of Western Civilization. New York, Walker, 1971.

King, Jere, C. Generals and Politicans. Berkeley, University of California Press, 1951.

King, Michael. New Zealanders at War. Auckland, William Heinemann, 1981.

Kingsford, Charles L. The Story of the Royal Warwickshire Regiment. London, Country Life and George Newnes, 1921.

Kinross, Lord. Atatürk: The Rebirth of a Nation. London, Weidenfeld and Nicolson, 1964.

Kinross, Lord., Atatürk .Bir Milletin Yeniden Doğuşu. Çev.,Ayhan Tezel, İstanbul, 1972.

Kirchberger, Joe H. The First World War: An Eyewitness History. New York, Facts on File, 1992.

Knight, Frank. The Dardenelles Campaign. London, MacDonald, 1970. 
Knight, Frank. Çanakkale Savaşı . Ankara, Harp Akademileri Komutanlığı, 1971.

Knvett, R. Hugo, "Over tehere" With the Australians. London, Hodder and Stoughton, 1918.

Koebsel, Eberhard. Der Kampf um die Dardenellen. Gutersloh, C. Bertelsmann, 1936.

Koeltz, Louis. La Guerre de 1914-1918: Les Opérations militaires. Paris, Sirey, 1966.

Kolenkovskiy, A.K. Dardenelskaya Operatsiya. Moskva, Voennaya Akademiya Raboçe-Krestyanskoy Krasnoy Armii im M.V. Frunze, 1938.

Koss, Stephen. Asquith. New York, St. Martinís Press, 1976.

Koss, Stephen. Lord Haldane: Scapegoat for Liberalism. New York, Columbia University Press, 1969.

Kraus, Theodor. Şanll Yavuz ve Midilli. Çev. Mehmet Çağrı-Günay Yalvaç, İstanbul, Demir Yayınları, 1974.

Kurat, Akdes Nimet. Birinci Dünya Savaşı Sırasında Türkiye'de Bulunan Alman Generalleri Raporları. Ankara, Türk Kültürünü Araştırma Enstitüsü Yayınları, 1966.

Kurtoğlu, Fevzi. Cihan Harbinde Deniz Muharebeleri :Türk Donanmast Ne Yaptı?, İstanbul, Ahmet Kamil Matbaası, 1928.

Kurtoğlu, Fevzi, Çanakkale 18 Mart 1915. İstanbul, Deniz Basımevi, 1935.

Kurtoğlu, Fevzi. Türklerin Deniz Muharebeleri. İstanbul, 1937.

Kurtoğlu, Fevzi. Gelibolu ve Yöresi Tarihi. Ankara, T.T.K. Basımevi, 1938.

Laffin, John. Damn the Dardenelles! The Agony of Gallipoli. Londra,Osprey Publishing 1980-1989.

Laffin, John. British Butchers and Bunglers of World War One. London, Alan Sutton, 1988.

Laffin, John. Digger: The Legend of the Australian Soldier. Melbourne, Macmillan, 1986.

Laffin, John. Ed. Letters From the Front, 1914-1918. London, J. M. Dent, 1973.

Laird, John. The Australians Experince of War. Dalinghurst, Mead and Beckett, 1988.

La Maziére, Pierre. L'Hopital Chirurgical Flottant. Paris, Albin Michel, 1919.

Larcher, M. La Guerre Turque dans la Guerre Mondiale. Paris, Etienne Chiron and Berger Levrault, 1926.

Larcher, M. Büyük Harpte Türk Harbi. I., Çev. Mehmet Nihat, İstanbul, 1927.

Latter, J. C. The History of the Lancashire Fusiliers. 2 Vols. Aldershot, Gale and Polden, 1949. 
Laurens, Adolphe. Histoire de la guerre sous-marine allamande (1914-1918). Paris, Socièté d'Editions Geographiques Maritimes et Coloniales, 1930.

Layman, R. D. Naval Aviation in the First World War: Its Impact and Influence. Annapolis, Naval Institute Press, 1996.

Lee, Neville. Commemoration of the 75th Anniversary of the Anzac landing in the Gallipoli. 1990.

Legg, Frank. The Gordon Bennet Story. Sydney, Angus and Robertson, 1965.

Lewis, Brian. Our War: Australia During World War I. Melbourne, Melbourne University Press, 1980.

Lewis, Bruce. A Few of the Firs. Conshohocken, Combined, 1996.

Liddel Hart, Basil H. The Decisive Wars of History: A Story in Strategy. London, G. Bell, 1929.

Liddle Hard, Basil H. The Real Waar, 1914-1918. Boston, Little Brown, 1930.

Liddle Hard, Basil H. A History of World War, 1914-1918. Boston, Little Brown, 1930.

Liddle Hard, Basil H. Trough the Fog of War. London, Faber and Faber 1938.

Liddle, Peter H. The Airmanís War 1914-1918. Poole, Balandford Press, 1987.

Liddle, Peter H. Gallipoli 1915: Pens, Pencils, and Cameras at War. London, Brasseyís, 1985.

Liddle, P.H., Men of Gallipoli: The Dardenelles and Gallipoli Experience, August 1914 to January 1916. London, Allen and Unvin, 1976.

Liddle, Peter H. The Sailorís War, 1914-1918. Poole, Blandford Press, 1985.

Liddle, Peter H. The Soldierís War, 1914-1918. London, Blandford Press, 1988.

Liddle, Peter H. "The Dardenelles Gallipoli Campaign: Concept and Execution." Home Fires And Foreign Fields: British Social and Military Experience in the First World War. Edited by,. Peter Liddle, London, Brasseyís, 1985.

Lloyd, George, David (Earl Lloyd George of Dwyfor). War Memoirs. 6 Vols. London, Nicolson and Watson, 1933-36.

Lockhart, J. G. The Sea Our Heritage. London, Geofrey Bles, 1940.

Londres, Alber. Si je tíoublie Constantinople. Paris, Union gÈnÈrale díÈdition, 1985.

Longmore, C. The Old Sixteenth: Being a Record of the $16^{\text {th }}$ Batallion, A. I. F. During The Great War, 1914-1918. Perth, Imperial, 1921.

Lorey, Herman, Türk Sularında Deniz Hareketleri, Çev., Tacettin Talayman, .II., İstanbul, 1946.

Lucas, Charles. Ed. The Empire at War. 6 Vols. London, Oxford University Press, 1921-1926.

Ludwig, Emil, Yavuz İle Midilli'nin Yolculuğu. Çev., Arif Gelen, İstanbul, 1968. 
Lushington, R. F. A Prisoner With the Turks, 1915-1918. London, Simpkin, Marshall, Hamilton, and Kent, 1923.

Lynn, Escott. Lads of the Lothians. London, Chambers, 1920.

Lyons, Michael. World War I: A Short History. Englewood Cliffs, Prentice Hall, 1994.

M. Fahri. Çanakkale Muharebeleri'nden Çıkartma Hususunda Alınan Dersler. İstanbul, Türkiye Basımevi, 1933.

MP, An. [Aubrey Herbert]. Monz, Anzac and Kut. London, Edward Arnorld, 19191930.

McAdie, Alexander. War Weather Vignettes. New York, Macmillan, 1925.

McCarty, Dudley. Gallipoli to the Somme: The Story of C. E. W. Bean. London, Leo Cooper, 1983.

MacCustra, L. Gallipoli Days and Nights. London, Hodder and Stoughton, 1916.

McDonagh, Michael. The Irish at the Front. London, Hodder and Stoughton, 1916.

Macdonald, Lyn. 1915: The Death of Innocence. London, Headline Books, 1993.

Macdonald, Lyn. 1914-1918: Voices \& Images of the Great War. London, Joseph Donald, 1988.

Macdonald, Lyn. The Roses of No Manís Land. London, Michael Joseph, 1980.

McEntee, Girard, L. Military History of the World War. New York, Charles Scribnerís Sons 1937.

Macfie, A. L. Atatürk. London, Longman, 1994.

McGibbon, Ian. The Path to Gallipoli: Defending New Zealand, 1840-1915.

MacKay, Ruddock F. Balfour: Intellectuel Statesman. Oxford, Oxford University Press, 1985.

MacKay, Ruddock, F. Fisher of Kilverstone. Oxford, Clarendon Press, 1973.

Mackenzie, Clutha N. The Tales of a Trooper. London, John Lane , 1921.

Mackenzie, Compton. Gallipoli Memories. London, Cassel, 1929.

Mackenzie, K. W. For Want of A Nail: The Impact on War of Logistics and Comminications. London, Brasseyís, 1989.

MacKernan, Michael. The Australian People and the Great War. Melbourne, Thomas Nelson, 1980.

McLoughlin, Redmont. The Escape of the Goeben: Prelude to Gallipoli. London, Seeley Service, 1974.

McLaughlin, Redmond. Yavuz'un Kaçışı, Çev., Nejat Dalay, [İstanbul], 1978.

MacMunn, George Behind the Scenes in Many Wars, Being the Military Reminiscences of George MacMunn. London, John Murray, 1930. 
McPherson, William L. A Short History of the Great War. New York, G.P. Putnamís Sons 1920.

McPherson, William L. The Strategy of Great War. New York, G.P. Putnamís Sons, 1919.

McQueen, Humprey. Gallipoli to Petrov: Arguing With Australian History. Sydney, George Allen and Unwin, 1984.

Magnus, Philip. Kitchener: Portrait of an Imperialist. London, John Murray, 1958.

Mahmut. Seddülbahir Muharebesi. Isparta, İlkadım Basımevi, 1933.

Mahmut (Bnb.). Seddülbahir'in İlk Şanlı Müdafaası. Konya, Yeni Anadolu Basımevi, 1935.

Malthus, Cecil. Anzac: A Retrospect. Chiristchurc, Withcombe and Tombs, 1965.

Manchester, William. Visions of Glory, 1874-1932. Vol. I. The Last Lion: Winston Spencer Churchill. Boston, Little, Brown, 1983.

Mansfield, J., Gallipoli. London, 1956.

Mantey, Eberhard von. Auf See unbesiegt mit Bildern gefallener Helden. 2 Vols. Minich, Lehman, 1921-22.

March, Francis A. History of the World War: An Authentic Narrative of the Worldis Greatest War. Philedelphia, United Publishers, 1919.

Marder, A. J. From dardenelles to Oran. London, Oxford University Press, 1974.

Marder, A. J. Portrait of an Admiral: The Life and Papers of Sir Herbert Richmond. Cambridge, Harvard University Press, 1952.

Marder, A. J. The War Years to the Eve of Jutland, Vol. 2. From the Dreadnought to Scapa Flow: The Royal Navy in the Fisher Era, 1904-1914. London, Oxford University Press, 1965.

Marine-Archiv und Kriegsgeschichfliche Forchungs anstalt deheers. Der Krieg zur See. 1914-1918: Der Krieg in den t, rkischen Gewassern. (Ed. Herman Lorey) 2 Vols. Berlin, E. S. Mittler, 1928-38.

Marshall, S. L. A. World War I. New York, American Heritage, 1964-1987.

Marshall, William. Memories of Four Fronts. London, Ernest Benn, 1929.

Masefield, John. Gallipoli. London, William Heinemann, 1916.

Maurice, Fraderick. British Strategy. London, Constable, 1929.

Maurice, Frederick. Lessons of Allied Cooperation: Naval Military and Air 19141918. London, Oxford University Press, 1942.

Maurice, Frederick. The $16^{\text {th }}$ Foot: A History of the Bedfordshire and Hertfordshire Regiment. London, Constable, 1931.

Maxwell, J. Hell's Bells and Mademoselles. Sydney, Angus and Robertson, 1932.

Mehmet Celalettin. Harbi Umumide Çanakkale Muharebetı Berriyesi, Kumkale Muharebatı. İstanbul, Erkan-1 Harbiye Mektebi Matbaası, 1336 (1920). 
Mehmet Emin Süleymaniyeli. Harb-I Umumide Osmanl Cepheleri Vekayii. İstanbul, Erkanı Harbiye Mektebi Matbaası, 1338 (1922).

Mehmet Nihat. Harb-i Umumi'de Seddülbahir (Cenub Grubu) Muharebetı. İstanbul, Matbaa-i Askeriye, 1336 (1920).

Mehmet Nihat Bursalı. Büyük Harpte Çanakkale Seferi. İstanbul, İlhami Fevzi Matbaası, 1926.

Mehmetcik ve Anzaklar, Ankara, Türkiye İş Bankası, 1987.

Melrose, Andrew. Russia the Balkans and the Dardenelles, London, 1915.

Members of the Regiment. History of the 5 th Royal Gurkha Rifles (Frontier Force) 1858-1928. 2 Vols. Aldershot, Gale and Polden, (t.y)

Men of Anzac, The. The Anzac Book. Edited by C. E . W. Bean, London, Cassel, 1919.

Mengül, Sabri. Türk Boğazlarının Tarihi (Çanakkale ve Karadeniz) . İstanbul. Deniz Matbaacılık, 1937.

Merle, Ferdinant. L'Admiral Guépratte. Brest, Edition de la cité, 1988.

Mete, İzzettin. Tarihimizin İhtişamı ve Cihandaki Yerimiz. İstanbul, Türkiye Basımevi, 1967.

Michelsen, Andreas. Der U-bootskrieg 1914-1918. Leipzig, K. F. Koehler, 1925.

Middlebrook, Martin. Ed. The Diaries of Private Horace Bruckshaw, 1915-1916. London, Scholar Press, 1979.

Midwinter, C. Memoirs of the $32^{\text {nd }}$ Field Ambulance, $X$ (Irish) Division. Privately Printed, 1933

Mikush, Dagobert von. Mustapha Kemal. Tarnsleted by John Linton. Garden City, NY; Doubleday, Doran, 1931.

Milne, A. Berkeley. The Flight of the Goeben and Breslau. London, Eveleigh Nash, 1921.

Miquel, Pierre. La Grand Guerre. Paris, Fayard, 1983.

Mitchell, Elyne. Light Horse: The Story of Australiais Mounted Troops. Melbourne, Macmillan, 1978

Mitchel Report, The. Report on the Enemy Defense of the Dardenelles Straits. London, Dardanelles Committee, 1921.

Mitchell, T. J., and G. M. Smith. Casualties and Medical Statistics of the Great War: Offical Medical History of War. Londra, His Majestyís Stationery Office, 1931.

Monash, John. The War Letters of General Monash. Edited by F. M. Cutlack, Sydney, Angus And Robertson, 1935.

Monasterev, N. Birinci Dünya Harbinde Karadeniz Sephesi. (Çev. Afif Tuğrul), İstanbul, 1948. 
Montgomary, Ina. John Hugh Allen of the Gallant Company: A Memoir. London, Edward Arnold, 1919.

Moorehead, Alan, Gallipoli, London, Hutchinson, 1956-1967.

Moorehead, Alan. Çanakkale Geçilmez, "Gallipoli”, İstanbul,1972.

Moorehouse, Geofrey. Hell's Foundations: A Social History of the Town Bury in the Aftermath of the Gallipoli Campaign. London, Hodder and Stoughton, 1992.

Mooris, Jan. Fisherís Face or, Getting to Know the Admiral. New York, Random Huose, 1965.

Moreau, Laurent. A Bord du Cuirassé “Goulois" (Dardenelles-Salonique 19151916). Paris, Payot, 1930.

Morgan, Ted. Churchill: Young Man in a Hurry, 1874-1915. New York, Simon and Schuster, 1982.

Morgenthau, Henry. Secrets of the Bosporus: Constantinople 1913-1916. London, Hutchinson, 1918.

Morgenthau, Henry. Ambassador Morgenthauís Story . U.S.A., 1918.

Morrow, Edgar. Iron in the Fire. Sydney, Angus and Robertson, 1934.

Moseley, Sydney A. The Truth About the Dardenelles. London, Cassell, 1916.

Moseley, Sidney. Çanakkale Hakikatleri. Çev., Hüsamettin, İstanbul, Matbaa-i Amire, 1332.

Mousharrafa, M. M. Atatürk: A Biography. Cairo, Anglo-Egyptian Bookshop,(t.y)

Moynihan, Michael, Ed.. People War, 1914-1918. Newton Abbot, David and Charles, 1973.

Moynihan, Michael, Ed.. A Place called Armegeddon: Letters From the Great War. London, David and Charles, 1975.

Muhasiboğlu, Fuat. Çanakkale Zaferi 60. Yılı. İstanbul, Özdemir Basımevi, 1975.

Mullay, B. R. Bugle and Kukri: The Story of the 10 th Princess Mary's Own Gurkha Rifles. Edinburg, Blackwood, 1957.

Mure, A. H. With the Incomparable $29^{t h}$. London W. And R. Chambers, 1919.

Murphy, C. C. R. Soldiers of the Prophet. London, John Hogg, 1921.

Murphy, C. C. R. History of the Suffolk Regiment 1914-1927, The. London, Hutchinson, (t.y)

Murray, Joseph. Gallipoli As I saw It. London, W. Kimber, 1965.

Murray, Joseph. Call to Arms: From Gallipoli to the Western Front. London, William Kimber, 1980.

Mustafa Kemal Arıburnu'nda, Ankara. (t.y),

Mustafa Kemal Atatürk. Anafartalar Muharebatı'na Ait Tarihçe, (Yay. Uluğ İğdemir), 2.bs., Ankara, Türk Tarih Kurumu, 1990. 
Mustafa Kemal Atatürk. Arıburnu Muharebeleri Raporu, (Yay. Uluğ İ̆gemir), 3.bs. Ankara, T.T.K., 1990.

Mustafa Kemal Ariburnu'nda Sergisi, (Haz., Prof.Dr. Demir Uğur), Ankara ,T.T.K. Basımevi, 1974.

Mühlmann, Carl. Das Deutsch-Türkishe Waffenbündnis Im Weltkriege. Leipzig, Verlag Koehler and Amelang, 1940.

Mühlmann, Carl, Ed. Der Kampf um die Dardenellen 1915. Band 16, Reichsarchiv Schlachten des Weltkriegs. Oldenberg, G. Stalling, 1927.

Mühlman, (Dr. Gnrl). Çanakkale Muharebesi 1915. Çev. Mehmet Cemal, Kastamonu, Vilayet Matbaası, 1933.

Mühlman, Carl, Çanakkale Savaşı: Bir Alman Subayının Notları. İstanbul, 1998.

Münim Mustafa, Cepheden Cepheye 1914-1918, I., İstanbul, 1940.

Mütercimler, Erol - Öke M. Kemal. İngilizlerin Gaspettĭ̌i Sultan Osman. İstanbul, 1991.

Mütercimler, Erol. Destanlaşan Gemilerimiz. İstanbul, Kastaş A.Ş. Yay., 1987.

Naismith, George. G. Canada's Sons and Great Britain in the World War. Toronto, John C. Winston, 1919.

Nalbandoğlu, Muhittin. Çanakkale Aslanları. İstanbul, Kalem Yayıncılık, 1981.

Neilson, Keith. Strategy and Supply: The Anglo-Russian Alliance, 1914-17. London, George Allen and Unvin, 1984.

Nekrasov, George. North of Gallipoli: The Black Sea Fleet at War, 1914-1917. East European Monographs No. CCCXLIII. Boulder, East European Monograph (Distrubuted by Columbia University Press), 1992.

Nelson, Robert, Frank Morgan, Peter Breen, Stuart Read, and David Evans. A Pictorial History of Australians at War. London, Paul Hamlyn, 1970.

Nevinson, Henry W. The Dardenelles Campaign. London, Nisbet, 1918.

Nevinson, Henry W. Last Changes Last Chances. London, Nisbet, 1928.

Newbolt, Henry. A Naval History of the War, 1914-1918. London, Hodder and Stoughton, 1920.

Newbolt, Henry. Submarine and Anti-Submarine. London, Longmans, Green, 1918.

Newton, L. W. The Story of the Twelfh: A Record of the 12 th Battalion, A. I. F. During the Great War of 1914-1918. Hobart, J. Walch, 1925.

Nicolson, G. W. L. The Fighting Newfounlander: A History of Royal Newfounland Regiment. Newfounland, The government of Newfounland, (t.y).

[Nicolson, Lothian, and H. T. MacMullen.] History of the East Lancashire Regiment in the Great War, 1914-1918. Liverpool, Littlebury Brothers, 1936.

Nihat. Harbi Umumide Seddülbahir Grubu Muharebatt. İstanbul, Matbaa-i Askeriye, 1336. 
Niyazi, 1915 Çanakkale Mahşeri, (y.y), (t.y).

North, John, Gallipoli, The Fading Vision, London, Faber and Faber, 1936.

Nutku, Emrullah. Çanakkale Şanlı Tarihe Bir Bakış. İstanbul, 1960.

Oatts, L. B. Proud Heritage: The Story of the Highland Light Infantry. London, Thomas Nelson, 1961.

ODTÜ 30. Kuruluş Yıldönümü "Çanakkale Savaşları'nın Askeri ve Siyasi Yönü" Sempozyumu Bildirileri, Editör., Mete Tunçoku, Ankara, Orta Doğu Teknik Üniversitesi, 1987.

Ogilvie, D. D. The Fife and Forfar Yeomanry and 14 th (F. And F. Yeo) Battn., R, H., 1914-1919. London, John Murray, 1921.

Olden, A.C. N. Western Cavalry in the War: The Story of the 10 th Light Horse. Melbourne, Alexander McCubbin, (t.y).

Ollard, Richard. Fisher and Cunningham: A Study in the Personalities of the Churchill Era. London, Constable, 1991.

O'Neill, H. C. The Royal Fusiliers in the Great War. London, William Heinemann, 1922.

18 Mart 1915 Çanakkale Geçilmez. Yay. Çanakkale Kültür ve Yardımlaşma Derneği, Ankara, 1976.

18 Mart 1915 Çanakkale Şehitlerini Anma Günü. 55. Yıl. (Yay. Milli Türk Talebe Birliği, İstanbul, Fatih Yayınevi, 1970.

18 Mart Çanakkale Zaferi. İstanbul, Halk Basımevi, (t.y).

18 Mart Çanakkale Zaferi. İstanbul, Harp Akademleri, 1970.

18 Mart Çanakkale Zaferi. İstanbul, Harp Akademileri, 1981.

18 Mart 1915 Çanakkale Geçilmez. Ankara, Çanakkale Kültür ve Yar. Der., 1976.

Onur, Necmi, Çanakkale Savaşları ve Şehitler Abidesi, İstanbul, 1960.

Orga, I. and M. Atatürk. London, Michael Joseph, 1962.

Owen, Frank. Tempestuous Journey: Lloyd George- His Life and Times. New York, McGraw Hill, 1955.

Oxford and Asquith, Earl of. Memories and Reflections, 1852-1927. 2 Vols. London, Cassel, 1928.

Ozanalp, Osman. Çanakkale Savaşları İstanbul, Askeri Matbaa, 1939.

Ozankan, Cenap. Mustafa Kemal'in Anafartalar Destanı. İstanbul, İnkılap Kitabevi, 1960.

Öğütveren, Enver. Çanakkale'den Anıtkabir'e. Ankara, Ayyıldız Matbaası, 1971.

Öke, Mim Kemal - Mütercimler, Erol. Sultan Osman, İstanbul, (t.y).

Önder, Cahit. Yaşayan Çanakkaleli Muharipler. (Atatürk'ün Silah Arkadaşları Doğumunun 100. Ylll), İstanbul, 1981. 
Özdemir, Gürtekin. Çanakkale Savaşları ve Savaş Alanında Gezi. İstabul, 1990.

Özel, Mehmet. Cephelerden Kurtuluş Savaşı'na, İmparatorluktan Cumhuriyete. Ankara, Kültür Bakanlığı , Güzel Sanatlar Genel Müdürlüğü, 1992.

Özgen, Abdurrahman Ateş: Çanakkale ve Sakarya Meydan Muharebelerinde Atatürk'ün Büyük Zaferi. [İstanbul], Bayrak Yayınevi, 1997.

Öztürk, Bekir. Şiirimizde Çanakkale Savaşları. Konya, Mimoza Yayınlanı, 1995.

Palue-Marmont, M. Le général Gouraud. Paris, Plon, 1939.

Patterson, J. H. With the Zionist in Gallipoli. London, 1916.

Payne, Robert. The Great Man: A Portrait of Winston Churchill. New York, Coward, McCann and Geoghegan, 1974.

Pearl, Cyril. Anzac Newsreel: A Picture History of Gallipoli. Sydney, Ure Smith, 1963.

Pedersen, P. A. Images of Gallipoli: Photographs From the Collection of Ross J. Bastiaan Melbourne, Oxford University Press, 1988.

Pedersen, P. A. Monash as Military Commander. Carlton, Melbourne University Press, 1985.

Pehlivanlı, Hamit. "Çanakkale Muharebeleri Sırasında Müttefiklerin Propagandası ve Karşı1 Propaganda", A.A.M.D. 7, 21 (Temmuz 1991): 535-552.

Pelling, Henry. Winston Churchill. New York, E. P. Dutton, 1974.

Pemberton, T. J. Gallipoli Today. London, Ernest Benn, 1926.

Pepeyi, Haluk Nihad. Çanakkale (Şiir). [Ankara], Çankaya Basımevi, 1938.

Pepeyi, Haluk Nihad Çanakkale: Destan, Ankara, Kültür Bakanlığı Yayını, 1981.

Perk, Kadri, Çanakkale Savaşları Tarihi, C.I-II, (Askeri Mecmua, Sayı.116 Eki), İstanbul, 1939-1940.

Petre, F. Lorraine. The History of the Norfolk Regiment, 1685-1918. 2 Vols. Norwich, Jarrold, (t.y).

Philipson, C. And Buxton N. The Question of the Bosphorus and the Dardenelles. London Stevens and Haynes, 1917.

Pitt, Barrie and Peter Young, Eds. Purnellis History of the First World War. London, Purnell for B.P.C. Publishing, 1969-1971.

Ponicaré, Reymond. Au sevice de la France. 7 Vols. Paris, Plon, 1930-31.

Poincaré, Reymond. The Memoirs of Raymond Poincaré. Çev. George Arthur, New York, Doubleday Doran, 1931.

Pollard, A. F. A Short History of the Great War. London, Methuen, 1920.

Pomiankowski, Joseph. Der Zusammenbruch des Ottomaischen Reiches: Erinnerungen an die Türkeaus der Zeit des Weltkrieges. Zürich, Amalthea, Verlag, 1928. 
Ponting, Clive. Churchill. London, Sinclair-Stevenson, 1994.

Powell-Edwards, H. I. The Sussex Yeomanry and $16^{\text {th }}$ (Sussex Yeomanry) Battalion Royal Sussex Regiment, 1914-1919. London, Andrew Melrose, 1921.

Powles, C. G. The History of the Canterbury Mounted Rifles, 1914-1919. Auckland, Whitcombe and Tombs, 1928.

Presland, John. Deedes Bay: A Study of Sir Wyndham Deedes, 1883-1923. London, Macmillan, 1942.

Price, W. H. With the Fleet in the Dardenelles During the Campaign in teh Spring of 1915. London, Andrew Melrose, 1915.

Priestman, E. Y. With a Baden Powell Scout in Gallipoli: A Record of the Belton Bulldogs. London, Routledge, 1916.

Prigge, E. R. Der Kampf um die Dardenellen. Weimar, G. Kiepenheuer, 1916.

Prior, Robin. Churchill's 'World Crisis' as History. London, Croom Helm, 1983.

Pugsley, Chiristopher. Gallipoli: The New Zealand Story. Auckland, Hodder and Stoughton 1984.

Puleston, W. D. The Dardenelles Expedition: A Condensed Study. Annapolis, U. S. Naval Institute, 1927.

Puleston, William Dilworth. High Command in the World War. New York, Charles Scribnerís Sons, 1934.

Purdom, Charles B., Ed. Everyman at War: Sixty Personal Narratives of the War. New York, E. P. Dutton, 1930.

Raleigh, Walter, and H. A. Jones. History of the Great Based on Official Documents. The War in the Air. 6 Vols. London, Oxford University Press, 192337.

Ralle, Charles. Çanakkale Seferi, Çev.Nihat Asım, İstanbul, 1337.

Rasor, Eugene L. British Naval History Since 1815: A Guide to the Literature. New York, Garland, 1990.

Ray, Cyril. The Lancashire Fusilier, London, Leo Cesper, 1971.

Raymond, Ernest. Tell England. London, Cassell, 1922.

Raymond, Ernest. The Story of My Days. London, Cassel, 1968.

Regan, Geofrey. Great Military Disasters: A History of Incompetence on the Battle Field. New York, M. Evans, 1987.

[Regimental Committee]. History of the East Lancashire Regiment in the Great War 1914-1918. Liverpool, Littleburg Brothers, 1936.

Regimental History Committee. History of the Dorsetshire Regiment 1914-1919. Dorchester, Henrty Lyng, (t.y).

Reishsarchiv. Der Weltkrieg 1914 bis 1918: Die militarischen operationen zu Lande. 14 Vols. Berlin, E. S. Mittler, 1925-1944. 
Reid, John. The Australian Artists at War: Complied From the Australian War Memorial Collection. 2 Vols. Melbourne, Sun Books, 1977.

Renouvın, Pierre, I. Dünya Savaşı, Çev. Teoman Tunçdoğan, İstanbul, 1993.

Repington, Charles a Court. The First World War, 1914-1918. 2 cilt, London, Constable, 1920.

Ribblesdale, Lord. Charles Lister: Letters and Recollections. New York, Charles Scribnerís Sons, 1917.

Rivoyne, L'Expedition des Dardenelles, 1914-1915, Paris, 1923.

Robbins, Keit, The First World War. New York, 1993.

Robertson, John. ANZAC and Empire: The Tragedy and Glory of Gallipoli. London, Leo Cooper, 1990.

Robertson, William. Soldiers and Statesmen, 1914-1919. 2 Vols.., London, Cassell, 1926.

Robson, L. L. The First Australian Imperial Force: A Study of Its Recruitment, 1914-1918. Melbourne, Melbourne University Press, 1970.

Rose, Norman. Churchill: The Unruly Giant. New York, Free Press, 1994.

Roskill, S. W., Ed. The Naval Air Service, 1914-1918. London, Navy Recordss Society, 1969.

Roskill, Stephen. Churchill and the Admirals. London, William Colins, 1977.

Roskill, Stephen. Hankey: Man of Secrets, 1: 1877-1918. New York, St. Martinís Press, 1970.

Ross, Jane. The Myth of the Digger: The Australian Soldier in Two World Wars. Sydney, Hale and Iremonger, 1985.

Ross, Malcolm and Noel Ross. Light and Shade in War. London, Edward Arnold, 1916.

Roux, Charles. L'Expédition des Dardenelles. Paris, Armand Colin, 1920.

Roux, Charles Fr. Çanakkale Seferi, Çev. Mehmet Nihat-Asım, İstanbul, Matbaa-i Askeriye, 1337.

Rowland, Peter. David Lloyd George: A Biography. New York, Macmillan, 1975.

Royle, Trevor. The Kitchener Enigma. London, Michael Joseph, 1985.

Ruhl, Arthur. Antwerb to Gallipoli. New York, Charles Scribnerís Sons, 1916.

Rule, E. J. Jackaís Mob. Angus and Robertson, 1933.

Saim, Yahya, Hilalin Gölgesinde: (Çanakkale-Kutu'l-Emare Zafer Destanı) Ankara, Kültür Bakanlığı 1991.

Samancıgil, Kemal. Çanakkale Başlarken. İstanbul, Emniyet Kitabevi, 1944.

Samancıgil, Kemal. Anafartalar. İstanbul, Emniyet Kitabevi, 1944. 
Samancıgil, Kemal. Deniz Devletleri Boğuşuyor. İstanbul, Emniyet Kitabevi, (t.y)

Samson, C. R. Fights and Flights. London, Ernest Benn, 1930.

Sanders, Liman Von. Fünf Jahre Türkei. Berlin, August Scherl, 1919.

Sanders, Limann Von. Five Years in Turkey. U.S. Naval Institute, Annapolis 1927.

Sanders, Liman Von. Türkiye'de 5 Yıl. Çev. M. Şevki Yazman, İstanbul, 1968.

Saracoğlu, A. Cemalettin, Çanakkale Zaferi 5-18 Mart 1915, İstanbul, Gür Basımevi, 1935.

Saray, Mehmet, "İştirak Edenlerin Hatıralarına Göre Çanakkale Muharebeleri”, Çanakkale Muharebeleri 75 nci Yıl Armağanı, Ankara, Genkur. Bşk., (1990): 127.

Sarrail, Maurice P. Mon Commandement en Orient. Paris, Ernest Flammarion, 1920.

Sauer, Wilhelm. Admiral Souchon auf grosser Fahrt. Rutlingen,Entzli and Laiblin, 1938.

Savaş Menkıbeleri. Ankara, Gnkur. Harp Dairesi yayınlan, 1961.

Sazonov, Serge. Fateful Years, 1906-1916. London, Jonathan Cape, 1928.

Schmitt, Bernadotte E., and Harold C. Vedeler. The World in the Crucible 19141919. New York, Harper and Row, 1984.

Schon, Walter von. Die H^lle von Gallipoli: der Heldenkampf an den Dardenellen. Berlin, Ullstein, 1937.

Schuller, Phillip-F.E. Australia in Arms; a narrative of the Australasian imperial force And their achivement at Anzac. London, T.F. Unwin ltd., 1916.

Schulz, Hugh Edward. The Dardenelles campaign by General Liman von Sanders. Fort Humpreys, The Engineer School, 1931.

Sedat. Boğazlar Meselesi ve Çanakkale Deniz Muharebesinde Türk Zaferi. İstanbul, Askeri Matbaa, 1927.

Seddülbahir Muharebeleri. İstanbul, Harp Akademisi Basımevi, 1933.

Seddülbahir'de Sağ Cenahta Birinci Fırkanın Şehitler Sırtı Destanı. İstanbul, Matbaaa-i Askeriye, 1332 (1916).

Selahattin Adil. Harb-i Umumide Çanakkale Muharebetı Bahriyesi. İstanbul, Erkanı Harbiye Mektebi Matbaası, 1336.

Sellers, Leonard. The Hood Battalion; Royal Naval Division: Antwerp, Gallipoli, France 1914 - 1918. London, Leo Cooper, 1995.

Serle, Geofrey. John Monash: A Biography. Carlton, Melbourne University Press, 1982.

Sertelli, İskender. Çanakkale'de Küçük Ahmet'in Kahramanlı̆̆ı. İstanbul, Ahmet Sait Basımevi, 1938. 
Seymor, Alan and Richard Nile, Eds. Anzac: Meaning, Memory, and Myth. Londra, University of London, 1991.

Shadbolt, Maurice. Voices of Gallipoli. London, Hodder and Stoughton, 1968.

Shankland, Peter and Anthony Hunter. Dardenelles Patrol. London, William Collins, 1964

Shaw, S.J., and E. Kural Shaw. The History of the Ottoman Empire and Modern Turkey. C. 2, Cambridge, Cambridge University Press, 1976-77.

Shaw, S. J., and E. Kural Shaw. Osmanlı Imparatorluğu ve Modern Türkiye. Reform, Devrim ve Cumhuriyet: Modern Türkiye'nin Doğuşu, 1808-1975. C. 2, Çev. Mehmet Harmancı, İstanbul, E Yayınları, 1983.

Shotwell, James T., and Francis Deak. Turkey at the Straits: A Short History. New York Macmillan, 1940.

Silas, Ellis. Crusading at Anzac, Anno Domini, 1915. London, British Australasian, 1916.

Simpson, C. R. History of the Lincolnshire Regiment, 1914-1915. London, Medici Society, 1931.

Sixsmith, E. K. G. British Generalship in the Twentieth Century. London, Arms and Armour Press, 1970.

Sivri, İsmail. Atatürk'ün Çanakkale Savaşları. İstanbul, Karacan yayınları, 1981.

Smith, Clarence Jay. The Russian Struggle for Power 1914-1917. New York, 1956.

Smith, C. Jay, Jr. "Great Britain and the 1914-1915" Straits Agreement With Russia: The British Promise of November 1914" American Historical Review, 70 (1970): 1015-1034.

Smith, Michael Douglas. Britain, Russia the Gallipoli Campaign ant the Straits. Doktora Tezi, Florida State University, 1979.

Smith, Staniforth. Australian Campaigns in the Great War: Being a Concise History of the Australian Naval and Military Forces, 1914-1918. Melbourne, Macmillan, 1919.

Smithers, A. J. Sir John Monash. London, Leo Cooper, 1973.

Smyth, John. Leadership in Battle 1914-1918. Newton Abbot, David and Charles, 1975.

Snelling, Stephen. VCs of the First World War: Gallipoli. London, Allan Sutton, 1995.

Sparrow, Geoffrey, and J. N. MacBean Ross. On Four Fronts With the Royal Naval Division. London, Hodder and Stoughton, 1918.

Spiers, Edward. "Gallipoli.” In The First World War and British Military History. Ed. Briand Bond, Oxford, Clarendon, Press, 1991.

Stake, H. Fritz M. The Worcestershire Regiment. Kidderminster, Cheshire, 1928. 
Stamps, T. Dodson, and Vincent, Eds. A Short Military History of World War I. West Point, U. S. Military Academy, 1950.

Steel, Nigel. The Battlefields of Gallipoli: then and now, London, Leo Cooper, 1990.

Steel, Nigel, and Peter Hart. Defeat at Gallipoli. London, Macmillan, 1994.

Steel, Nigel-Peter Hart. Gelibolu, Yenilginin Destanı. Çev. Mehmet Harmancı, İstanbul, 1996.

Stegemann, Herman. Geschicte des Kriegs. 4 C. Stuttgart, Deutsche Verlags Anstalt, 1917-1921.

Stewart, A. T., and C. J. E. Peshal. The Immortal Gamble and the Part Played in It by H.M.S. Cornwallis. London, A. and C. Black, 1918.

Stewart, H. The New Zealand Division. Auckland, Whitcombe and Tombs, 1921.

Stiènon, Charles. L'Expédtion des Dardenelles: Sur le Chemin de Constantinople. Paris, Chapelot, 1916.

Stieve, Frederich. Isvolsky and the World War. London, 1926.

Still, John. A Prisoner in Turkey. John Lane, The Bodley Head, 1920.

Stoker, H. G. Straws in the Wind. London, Herbert Jenkins, 1925.

Stokesbury, James. British Concepts and Practices of Amphibious Warfare, 18671916. Doktora Tezi, Duke University, 1968.

Stokesbury, James L. A Short History of World War I. New York, William Morrow, 1981.

Stone Norman. The Eastern Front, 1914-1917. New York, Charles Scribnerís Sons, 1975.

Story of the Anzacs, The: An Historical Account of the Part Taken by Australia and New Zealand in the Great War. Melbourne, James Ingram, 1917.

Struz, Rudolph. Der Weltkrieg: Ein deutsches Voltsbuch vom dem Weltgeschehen 1914 bis 1918. Berlin, Verlag Scherl, 1933.

Student, A. The Gallipoli Campaign: An Outline of the Military Operations. London, Sifton, Praed, 1923.

Stuermer, Harry. Two War Years in Constantinople. Çev. F. Allen ve Harry Stuermer, New York, George H. Doran, 1917.

Sutton, F. A. One ñ Arm Sutton. New York, Viking Press, 1933.

Swing, Raymond. Good Evening. London, The Bodley Head, 1964.

Şefik. Çanakkale Destanında En Önemli Gün. İstanbul, Hüsnü Tabiat Matbaası, 1961.

Şiirimizde Çanakkale Savaşları, Derleyen, Bekir Öztürk, Konya, Mimar yayınları, 1995. 
Taffrail, Henry [Taprell Dorling]. Endless Story: Being an Account of the Work of the Destroyers, Flotilla-Leaders, Torpedo-Boats and Patrol Boats in the Great War. London, Hodder and Stoughton, 1935.

Taffrail, Henry [Taprell Dorling]. Swept Channels: Being an Accaunt of the Work of the Minesweepers in the Great War. London, Hodder and Stoughton, 1935.

Tale of a territorial The: Being a Record of Experience at Home and Abroad During the Years 1914, 1915 and 1916. Wellingborugh, Perkins, [1918].

Taylor, A.J.P. Politics in Wartime, London, Hamish Hamilton, 1964.

Taylor, A.J.P. English History, 1914-1945. New York, Oxford University Press, 1965.

Taylor, A.J.P. The Struggle for Mastery in Europe 1848-1918. London, Oxford, 1957.

Taylor, A.J.P. Illustrated History of the First World War. London, Hamish Hamilton, 1963.

Taylor, A.J.P., Ed. Lloyd George: A Diary by Frances Stevenson. New York, Harper and Row, 1970.

Taylor, Phil, and Pam Cupper. Gallipoli: A Battle Field Guide. Kenthurst, Kangaroo Press, 1989.

Taylor, Robert Lewis. Winston Churchill. The Biography of a Great Man, London, 1954.

Teichman, O. The Diary of a Yeomanry, M. O. London, Fisher Unwin, 1921.

Terraine, John. "1915-The End of an Epoch." The Journal of the Royal United Service Institution, 101 (1956): 76-79.

Terraine, John. White Hat: The New Warfare, 1914-18. London, Sidgwick, and Jackson, 1982.

Terraine, John. The First World War. London, Hutchinson, 1965-1983.

Testis, J'expedition Des Dardenelles, d'apprés les documents officiels Anglais. Paris, 1917.

Tezener, Ziver. Kahramanlık Şiirleri Antolojisi. İstanbul, 1990.

Thomas, Lowell. Les Corsaires sous-marins. Paris, Payot, 1930.

Thomazi, A. La Guerre Navale aux Darnelles. Paris, Payot, 1926.

Thomazi, A. Çanakkale Deniz Savaşı, Çev.Hüseyin Işık, Ankara, 1997.

Thomazi, A. Les Marins a terre. Paris, Payot, 1933.

Thompson, C. W. Records of the Dorset Yeomanry (Queen's Own) 1914-1919. Sherborne, F. Bennet and Co., The Parade, 1921.

Thompson, P. A. Lions Led by Donkeys: Showing How Vicyory in the Great War Was Achieved by Those Who Made the Mistakes. London, T. Werner Laurie, 1927. 
Thompson, R. R. The Fifty-Second. (Lowland) Division, 1914-1918. Glasgow, Maclehose, 1923.

Thomson, Alistar. Anzac Memories. Melbourne, Oxford University Press, 1994.

Thoumin, Richard. La Grande Guerre. 3 C., Renè Juliard, 1960.

Thoumin, Richard. The First World War. Ed. ve Çev. Martin Kieffer, London, Martin Secker and Warburg, 1963.

Throssell, Ric. My Fatherís Son. Melbourne, William Heinemann, 1989.

Till, Geofrey. "Brothers in Arms": The British Army and Navy at the Dardenelles ." In Facing Armageddon: The First World War Experienced. Edited by Hugh Cecil and Peter H. Liddle. London, Leo Cooper, 1996.

Tilton, Mary. The Gray Battalion. Sydney, Angus and Robertson, 1933.

Tisdall, Arthur Walderne St. Clair. Verses, Letters, and Remembrances of Arthur Walderne St. Calir Tisdall. London, Sidgwick and Jackson, 1916.

Topçu, Nurettin. Çanakkale. İstanbul, M. Sıralar Matbaası, 1952.

Torau - Bayle, Xavier. La campagne des Dardenelles. Paris, E. Chiron, 1920.

Trooper Bluegum [Hogue, Oliver]. Love Letters of Anzac. London, Andrew Melrose, 1916.

Troubridge, Laura. Memories and Reflections. London, William Heinemann, 1925.

Trumpener, Ulrich, Germany and the Ottoman Empire 1914-1918, Princeton, Princeton University Press, 1968.

Tuğrul, Afif. Bizim Harblerimiz. İstanbul, T.C. Deniz Basımevi, 1956.

Tunççapa, Şakir, Çanakkale Harbi Hatıralarım, İstanbul, 1958.

Tunçoku, A. Mete. Anzakların Kaleminden Mehmetçik: Çanakkale 1915, Ankara, Atatürk Araştırma Merkezi Yayını, 1997.

Tunçoku, Mete-Taşkıran Cemalettin, Çanakkale, Churchill ve Anzaklar, Çanakkale Churchill and Anzacs, Ankara, Genkur., Basımevi, 2000.

Tubby, A. H. A Consulting Surgeon in the Near East. London, Christophers, 1920.

Turner, John. British Politics and the Great War. Coalition and Conflict 1915-1918. New Haven, Yale University Press, 1992.

Tümerdem, İ.[İsmail].H.[Hakkı], Osmanlı Imparatorluğu Devrinde Büyük Meydan Muharebeleri ve Çanakkale Deniz Kara Harekatı. İstanbul, Cumhuriyet Matbaası, 1939.

Tyquin, Michael B. Gallipoli, The Medical War. The Australian Army Medical Services in the Dardenelles Campaign of 1915. Kensington, New South Wales University Press, 1993.

Uluaslan, Hüseyin. Çanakkale Tarihin Destanlar Diyarı. Yayınlayan, Çanakkale Turizm ve Tanıtma Derneği , İstanbul, Nurettin Uycan Matbaası, 1973.

Uluaslan Hüseyin. Gallipoli Campaign. İstanbul, 1986. 
Uluaslan, Hüseyin. Gallipoli Campaign. Çanakkale, Salih Zeki and Gürol Ulusalan, 1987.

Uluaslan, Hüseyin. Çanakkale. İstanbul, Nurettin Uycan Matbaası, (t.y).

Uluaslan, Hüseyin-Salih, Zeki. Çanakkale Savaşları. İstanbul, Nurettin Uycan Matbaası, 1981.

Ulubelen, Erol, Çanakkale Muharebesi. The Story of the great War. New York 1916, Aykaç Kitabevi, İstanbul, 1967.

Uluğ, Naşit Hakkı. Çanakkale Destanının 50. Yılı. Ankara, Güzel İstanbul Matbaası, 1966.

Usborne, C. V. Smoke on the Horizon: Mediterranean Fighting, 1914-1918. London, Hodder and Stoughton, 1933.

Uygun, Ali Galip. Çanakkale Muharebe Sahası Gezi Muhtırası. Yayınlayan, Harp Akademileri Komutanlığı, İstanbul, 1967.

Ülman, Haluk. Birinci Dünya Savaşı'na Giden Yol ve Savaş. 2. bs. Ankara, 1973.

Ünaydın, Ruşen Eşref, The Story of Gallipoli as recounted by Mustafa Kemal. 2 bs. Ankara, Ak yayınları, 1990.

(Ünaydın), Ruşen Eşref, Mustafa Kemal Über die Dardanellenkampfe im Weltkriege. Deutsch, von B.T. Graz, 1933.

(Ünaydın), Ruşen Eşref, Anafartalar Komutanı Mustafa Kemal İle Mülakat, İstanbul, Hamit Matbaası, 1930 .

Ünaydın, Ruşen Eşref, Çanakkale'de Savaşanlar Dediler ki. Ankara, T.T.K. Basımevi, 1950.

Ünaydın, Ruşen Eşref, Mustafa Kemal Çanakkale'yi Anlatıyor, Ankara, 1981.

Ünen, Nurettin. Dünkü ve Bugünkü Çanakkale, Ankara, Ulus Basımevi, 1947.

Vader, John. Anzac. London, New English Library, 1970.

Vahid. Tarihin En Mühim Harp ve Seferleri. İstanbul, Askeri Basımevi, 1932.

Vale, W. L. History of the Soth Staffordshire Regiment. Aldershot, Gale and Polden, 1969.

Vansittart, Peter. Voices from the Great War. London, Jonathan Cape, 1981.

Vassal, Joseph. Uncensored Letters From the Dardenelles. Written to His English Wife by a French Medical Officier of L'Corps Expéditionnarie d'Orient. London, William Heinemann, 1916.

Vassal, Joseph Marguerite Jean. Dardenelles, Serbie, Salonique. Paris, Plon-Nourrit Et Cie, 1916.

Vecihi, Başarın-Hürmüz Başarın. A Turkish view of Gallipoli: Çanakkale. Victoria, Richmond. (t.y) (Hodja educational resources co-operstive).

Vedel, Emile. Çanakkale'de Bahriyelerimiz. Çev. Ahmet Lütfullah, İstanbul, Matbaa-i Amire, 1332 (1916). 
Vat, Dan van der. The Ship That Changed the World: The Escape of the Goeben to the Darnelles in 1914. Bethesda, Adler and Adler, 1986.

Volkan, Vamik D., and Norman Itzkowits. The Immortal Atatürk: A Psychobiography. Chicago, University of Chicago Press, 1984.

Waite, Fred. The New Zealanders at Gallipoli. Vol. 1 of Official History of New Zealand's Effort in the Great War. Auckland, Whitcombe and Tombs, 19191921.

Walder, David. The Chanak Affair, London, Hutchinson and Co., 1969.

Walder, David. Çanakkale Olayı, Çev., M. Ali Kayabal, [İstanbul], Milliyet Yayınları, 1971.

Walker, Rob. To What End Did They Die?: Officers Died at Gallipoli. Upton upon Severn, R. W. Walker Publishing, 1985.

Wallace - Crabbe, Chris. The Shapes of Gallipoli. Warrandyte, K. Wallace-Crabbe at the Costwold Press, 1975.

Wallach, Jehuda L. Uneasy Coalition: The Entente Experience in World War I. Westport, Greenwood Press, 1933.

Wallach, Jehuda L., Bir Askeri Yardımın Anatomisi, Çev.Fahri Çeliker, Ankara, 1985.

Wallin, Jeffrey D. By Ships Alone: Churchill and the Dardenelles. Durham, Carolina Academic Press, 1981.

Wanlish, N. The History of the 14 th Battalion, A. I. F. Melbourne, Arrow, 1929.

Ward, C. H. Dudly. History of the 53 rd. (Welsh Division). Cardiff, Western Mail, 1927.

Ward, C. H. Dudly. Regimental Records of Royal Welsh Fusiliers. 4 Vols. London, Foster Groom, 1928-29.

Warner, Oliver. Admiral of Fleet: Cunningham of Hyndhope. Athens, Ohio University Press, 1967.

Wartham, H. E. Mustapha Kemal of Turkey. Boston, Little, Brown, 1931.

Watkins, Charles. Lost Endeavour. Privately Printed, 1971.

Weaver, Lawrence. The Story of the Royal Scots. London, Country Life and George Newnes, (t.y).

Weber, Frank. Eagles on the Crescent: Germany, Austria and the Diplomacy of the Turkish Alliance. 1914-1918. Ithaca and London, Cornell University Press, 1970.

Webster, F. A. M. The History of Fifth Battalion. The Bedfordshire and Hertfordshire Regiment (T.A.) . London, Frederick Warne, 1930.

Wedgwood, Josiah Clement. Essays and Adventures. London, Allen and Unwin, 1924.

Wedgwood, Josiah Clement. With Machine Guns in Gallipoli. London, Darling and Son, 1915. 
Welbirn, Suzanne. Lords of Death: A People, A Place, A Legend. Fremantle, Fremantle Arts Centre Press, 1982.

Weldon, L. B. "Hard Lying," Eastern Mediterranean, 1914-1919. London, Jenkins, 1925 .

Wester, Wemyss, Lady. The Life and Letters of Lord Wester Wemyss. London, Eyre and Spottiswoode, 1935.

Wester, Wemyss, Lord. The Navy in the Dardenelles Campaign. London, Hodder and Stoughton, 1924.

Westake, Ray. British Regiments at Gallipoli. London, Leo Cooper, 1966.

Whalley - Kelly, H. "Ich Dien" The Prince of Walesis Volunteers (South Lancashire) 1914-1934. Aldershot, Gale and Polden, 1935.

White, A. S. A Bibliography of Regimental History of the British Army. London, Society for Army Historical Research in Conjunction With the Army Museumís Ogilby Trust, 1965.

White, T. A. The "Fighting Thirteent": The History of the Thirteenth Battalion A.I.F. Sydney, N. P., 1924.

Whitehorn, A. C. And Thomas O. Marden. The History of the Welsh Regiment. Cardiff, Western Mail and Echo, 1932.

Whitton, Frederick E. The History of the Prince of Wales' Leinster Regiment. (Royal Canadians) 2 Vols. Aldershot, Gale and Polden, 1924.

Wilkie, A. H. Official War History of the Wellington Mounted Rifles Regiment 1914-1919. Wellington, Whitcombe and Tombs, 1924.

Wilkinson, Norman, The Dardenelles. Colour Sketches From Gallipoli. London, Longmans, Green and Co., 1915.

Wilkinson, Spenser. Government and the War. New York, McBride, 1918.

Williams, H. R. The Gallant Company: An Australian Soldierís Story of 1915-1918. Sydney, Angus and Robertson, 1933.

Williams, Jeffrey. Byng of Vimy: General and Governor General. London, Leo Cooper, 1983 .

Wilson, H.W., Büyük Harpte Deniz Muharebeleri, (Çev., Dz. Bnb. Lütfü Talat), İstanbul, Deniz Matbaas1, 1931.

Wilson, Michael. Destination Dardenelles: The Story of H.M.S. E 7. London, Leo Cooper, 1988.

Wilson, Trevor. The Myriad Faces of War. Cambridge, Polity Press, 1986.

Winston S. Churchill. Selections From His Writings And Speeches, London, 1952.

Winter, Denis. 25 April 1915: The Inevitable Tragedy. St. Lucia, University of Queensland Press, 1994.

Woods, William Seaver. Colossal Blunders of the War. New York, Macmillian, 1931. 
Woodward, David R. Lloyd George and the Generals. Newark, University of Delaware Press, London, Associated University Presses, 1983.

Woodward, Llewellyn. Great Britain and the War of 1914-1918. London, Methuen, 1967.

Wren, E. Randwich to Hargicourt (History of the Third Battalion, A.I. F. ). Sidney, R. R. G. McDonald, 1935.

Wylly, H. C. The Border Regiment in the Great War. Aldershot, Gale and Polden, 1924.

Wylly, H. C. The Green Howards in the Great War. Richmond, Yorkshire, [Butler and Tanner] , 1926.

Wylly, H. C. History of the Queenís Royal Regiment. 7 Vols. Aldershot, Gale and Polden, (t.y).

Wylly, H. C. Neill's "Blue Caps". 3 Vols. Aldershot, Gale and Polden, n.d. (t.y).

Wyrall, Everard. The West Yorkshire Regiment in the Great War, 1914-1918. 2. Vols. London, John Lane The Bodley Head, (t.y).

Wyrall, Everard. The Gloucestershire Regiment in the Great War, 1914-1918. London, Methuen, 1931.

Wyrall, Everard. The East Yorkshire Regiment in the Great War, 1914-1918. London, Harrison, 1928.

Wyrall, Everard. The Die-Hards in the Great War: A History of the Duke of Cambridgeis Own (Middlesex Regiment) 1914-1919. 2 Vols. London, Harrison and Sons, 1926-1930.

Yalçın, Osman. Çanakkale. 3.bs., Özyürek Yayınevi, İstanbul, 1981.

[Yalman], Ahmed Emin, Turkey in the World War. New Haven, Yale University Press, 1930.

Yazar, Necati (Yzb.). Çanakkale Muharebeleri. Ayyıldız Yayıncılık, Ankara, 1957.

Yazman, M. Şevki, Türk Çanakkale, Ankara,1938.

Yazman, M. Şevki. Çanakkale 18 Mart 1915-1950, Ankara, 1960.

Yeşiltepe, İsmail . Çanakkale Savaşları Kılavuzu. (y.y), (t.y).

Yıldıran, Orhan. Çanakkale Muharebeleri. Ankara, Genkur. Basımevi, 1966.

Yıldırım, Hüseyin, Çanakkale Savaşları Bibliyografyası, Çanakkale Savaşları 80. Yıl Armağanı, Ankara, Genkur. Bşk., Deniz Kuvvetleri Komutanlığı, 1995.

Yurdakuler. M. Seddülbahir Muharebesinde Kahraman 111/26 Alay. Ankara, 1951.

\section{HATIRALAR}

Ahmet İzzet Paşa [Furgaç], Feryadım, C.I., İstanbul, Nehir Yayınları, 1993.

Aker, (Mehmet) Şefik, Çanakkale-Arıburnu Savaşları ve 27. Alay. İstanbul, Askeri Matbaa, 1935. 
Anzac Memorial: Soldiers' Stories of Gallipoli. London, Fisher Unwin, 1916.

Ali Vahid Uryani zade. Çanakkale Cephesinde Duyup Düşündüklerim. İstanbul, Necm-i İstiklal Matbaası, 1332/1334 (1916).

Altay, Fahrettin, Imparatorluktan Cumhuriyete, (Fahrettin Paşa Anlatiyor) (Haz., Taylan Sorgun), İstanbul, Eko Matbaası, 1998.

Altıntaş, Ahmet. Ingiliz Akdeniz Kuvvetleri Başkomutanı Sir Ian Hamilton'un Hatıraları. Çanakkale 18 Mart Ünüversitesi, Atatürk ve Çanakkale Savaşları'nı Araştırma Merkezi Yayınları, Çanakkale, 1999.

Atatürk, Mustafa Kemal, Atatürk'ün Anıları, (Haz., Dr. İsmet Görgülü), Ankara, 1997.

Atatürk, Mustafa Kemal. Anafartalar Muharebelerine Ait Hattralar. İstanbul, Sel Yayınları 1955.

Atatürk, Mustafa Kemal. Anafartalar Muharebatına Ait Tarihçe. (Yayınlayan, Uluğ İğdemir), Ankara, 1962.

Atay, Falih Rıfkı. Atatürk'ün Hatıraları, 1914-1919. Ankara, Türkiye İş Bankası Kültür Yayınları, 1965.

Atsız, Nihal. Çanakkale'ye Yürüyüş. İstanbul, 1933.

Bean, C. E. W. Gallipoli Correspondent: the Frontline Diary of C.E.W. Bean. Selected and Annotated by K.Fewster, Sydney, Allen and Unwin, 1990.

Bean, C. E. W. Front Line Gallipoli: Diaries From the Trenches. Selected and annotated by Kevin Fewster. Sydney, George Allen and Unvin, 1983.

Bean, C. E. W. Two Men I Knew: William Bridges and Brudenell White Founders of the A.I.F. Sydney, Angus and Robertson, 1957.

Bond, Brian, and Simon Robbins, (eds), Staff Officer: The Diares of Walter Guinnes (First Lord Moyne) 1914-1918. London, Leo Cooper, 1987.

Brock, Michael and Eleanor Brock, (eds.), H. H. Asquith, Letters to Venetia Stanley. Oxford: Oxford Universty Press, 1982.

Buley, E. C. Gloiorus Deeds of Australians in the Great War. London, Andrew Melrose, 1915.

Burness, Peter. The Nek. Kenthurst, Kangaroo Press, 1996.

Burrows, John W. The Essex Regiment. 5 Cilt, Southand- on-Sea, John H. Burrows, (t.y).

Burton, O. E. The Silent Division: New Zealanders at the Front, 1914-1919. Sydney, Angus and Robertson, 1935.

Butler, A. G. The Gallipoli Campaign. Vol. I , Part I, The Australian Army Medical Services in the War of 1914-1918. Melbourne, Australian War Memorial, 1930.

Bülkat, Mehmet Esat, Esat Paşa'nın Çanakkale Anıları, (Haz., İhsan Ilgar), İstanbul, Baha Matbaası, 1975. 
Cemal Paşa, Hatıralar, Itttihat ve Terakki, I. Dünya Savaşı Anıları, (Haz., Behçet Cemal), İstanbul, Hilâl Matbaacılık Kollektif Şirketi, 1977.

Cemal Pasha, Ahmed. Memoires of a Turkish Statesman, 1913-1919. New York, George H. Doran, 1922.

Çalışlar, Orgeneral İzzettin. Atatürk'le İkibuçuk Yıl Orgeneral Çalışlar'ın Anıları. (Haz., Dr. İsmet Görgülü - İzzeddin Çalışlar) İstanbul, Mataş A.Ş., 1993.

Çanakkale Gazileri Hatıraları. Dernek Yayını, (t.y), ( y.y).

Çanakkale'den Hatıralar, (Haz., Kadri Ener ) , İstanbul, Sucuoğlu Basımevi, 1954.

Çöl, Emin. Çanakkale - Sina Savaşlart. Ankara, Güryılmaz Matbası, 1977.

Dining, Hector. By-ways on Service: Notes From on Australian Journal. London, Constable 1918.

Donnel, Anne. Letters of an Australian Sister. Sydney, Angus and Robertson, 1920.

Drage, Charles. Chindwin to Criccieth: The Life of Godfrey Drage. Caernavon. Gwenlyn, 1956.

East, Ronald. (Ed.) The Gallipoli Diary of Sergeant Lawrence of the Australian Engineers 1st A.I.F. 1915. Carlton, Melbourne University Press, 1981.

Einstein, Lewis. Inside Constantinople: A Diplomatistis Diary During the Dardenelles Expedition. London, John Murray, 1917.

Elliot, G. F. Scott. War History of the $5^{\text {th }}$ Battalion Kingís Own Scottish Borderers. Dumfries, Robert Dinwiddie, 1928.

Esher, Reginald, Viscount. The Tragedy of Lord Kitchner. New York, E. P. Dutton, 1921.

Ewing, William. From Gallipoli to Bagdad. London, Hodder and Stoughton. (t.y).

Facey, A. B. A Fortunate Life. Fremantle, Fremantle Arts Centre, 1981.

Fallon, David. The Big Fight: Gallipoli to the Somme. London, Cassel, 1918.

Feuille, H. Face aux Turcs: Gallipoli, 1915. Paris, Payot, 1934.

Findlay, J. M. With the 8th cottish Rifles. London, Blackie, 1926.

Fisher, Admiral of the Fleet, Lord. Memoires. London, Hodder and Stoughton, 1919.

From Dartmouth to the Dardenelles: A Midshipmanís Log. (Edited by His Mother) London, William Heinemann, 1926.

Gallipoli Diary, London, Survey Dept., 1920.

Gökalp, Mehmet. "Bir Çanakkale Gazisinin Anıları", Hayat Tarih Mecmuası. C.2,S. 11 (Kasım 1976) s.75-78.

Görgülü, İsmet. Sesli Belgelerden Harp Hatıralart. İstanbul, Harp Akademileri, 1989. 
Gorlainov, Serge. Çanakkale ve İstanbul Boğazlart. Devlet-i Osmaniye - Rusya Siyaseti. (Çev. Macar İskender-Ali Reşad), İstanbul, Kanaat Matbaası, 1331 (1915)

Gücüyener, Şükrü Fuat. Çanakkale'de Kumkale Muharebesi. İstanbul, Resimli Su Basımevi 1932.

Gücüyener, Şükrü Fuat. Çanakkale'de İntepe Topçulart. Yeni Nesle Harp Hatıraları, İstanbul, 1932.

Gücüyener, Şükrü Fuat. Dün ve Bugün, Kahraman Kara Salih Çavuş'un Hayatı. İstanbul, 1953.

Gücüyener, Şükrü Fuat. Birinci Cihan Harbinde Tanıdığım Kahramanlar. İstanbul, 1956.

Hamilton, A. S. The City of London Yeomanry (Roughriders). London, Hamilton Press, 1936.

Hamilton, Ian, Gallipoli Diary. 2 Vols, London, Edward Arnold, 1920.

Hamilton, Ian. Gelibolu Günlü̈̆̈̈, (Çev.,Osman Öndeş), İstanbul,1972.

Hamilton, Ian. Ian Hamilton's Final Despatches. London, George Newnes, 1916.

Hamilton, Ian. Listening for the Drums. London, Faber and Faber, 1944.

Hamilton, Ian. Sir Ian Hamiltonís Despatches From the Dardenelles. London, George Newnes, 1915.

Hersing, otto. U-21 rettet die Dardenellen. Zurich, Amalthea Verlag, 1932.

History of the Dorsetshire Regiment, 1914-1919. Dorchester, Henry Ling , 1933.

Idriess, Ion L. The Desert Column . Sydney, Angus and Robertson, 1932-1951.

Ingle, Judith A. From Duntroom to the Dardenelles: A Bibliography of Lieutenant William Dawkins: Including His Diaries and Selected Letters. Canberra, J. Ingle, 1995.

Jerrold, Douglas. The Hawke Battalion: Some Personal Records of Four Years. London, Ernest Benn, 1925.

La Mazière, Pierre. L'Hopital Chirurgical Flottant. Paris, Albin Michel, 1919.

Lawrence, Cyril. The Gallipoli diary of Sergent Lawrence of the Australian engineers. Melbourne, 1983.

Lloyd George, David (Earl Lloyd George of Dwyfor). War Memoirs. 6 Vols. London, Nicolson and Watson, 1933-36.

Lushington, R.F. A Prisoner With the Turks, 1915-1918. London, Simpkin, Marshal, Hamilton, and Kent, 1923.

MP, An. [Aubrey Herbert]. Mons, Anzac and Kut. London, Edward Arnold, 19191930.

McCarhy, Dudley. Gallipoli to the Somme: The Story of C.E.W. Bean. London, Leo Cooper, 1983. 
McCustra, L. Gallipoli Days and Nights. London, Hodder and Stoughton, 1916.

Mackenzie, Compton. Gallipoli Memories. Garden City, Doran and Company, 1930.

Mackenzie, K. W. The Story of the $17^{\text {th }}$ Battallion, A.I.F. in the Great War. Sydney, Chipping, 1946.

MacMunn, George. Behind the Scenes in Many Wars, Being the Military Reminiscences of George MacMunn. London, John Murray, 1930.

Marshal, William. Memories of Four Fronts. London, Ernest Benn, 1929.

Mehmet Emin Süleymaniyeli. Gelibolu Hatıratı, İstanbul, Mektebi Harbiye Matbaasi, (t.y)

Montgomery, Ina. John Hugh Allen of the Gallant Company: A Memoir. London, Edward Arnold, 1919.

Moreau, Laurent. Â Bord du Cuirassé “Goulois" (Dardenelles-Salonique 19151916), Paris, Payot, 1930.

Morrow, Edgar. Iraon in the Fire. Sdney, Angus and Robertson, 1934.

Mure, A. H. With the Incomparable 29 th. London, W. And R. Chambers, 1919.

Murphy, C. C. R. The History of the Suffolk Regiment 1914-1927. London, Hutchinson (t.y).

Murray, Joseph. Call to Arms: From Gallipoli to the Western Front. London, William Kimber, 1980.

Murray, Joseph. Gallipoli As I Saw It. London, William Kimber, 1965.

Mühlman, Carl, Çanakkale Savaşı: Bir Alman Subayının Notları. İstanbul, Timas, 1998.

Münim Mustafa. Cepheden Cepheye, 914-918. Ihtiyat Zabiti Bulunduğum Strada Cihan Harbinde Kanal, Çanakkale ve Kafkas Cephelerine Ait Hatıralarım. C.I. İstanbul, Ege Basımevi, 1940 -1998.

Nevinson, Hanry W. The Dardenelles Campaign, London, Nisbet, 1918.

Newton, L. W. The Story of the Twelfth: A Record of the 12 th Battalion, A. I. F. During The Great War of 1914-1918. Hobart, J. Walch, 1925.

Okyar, Fethi. Ü̧̧ Devirde Bir Adam. (Haz., Cemal Kutay), İstanbul, Dilek Matbaası, 1980.

Oxford and Asquith, Earl of. Memoires and Reflections, 1852-1927. 2 Vols. London, Cassell 1928.

Patterson, J. H. With the Zionists in Gallipoli. London, Hutchinson, 1916.

Peaudelue, Léon Aimé. Aux Dardenelles, A Lemnos, sur les bords du Vardar; Souvenirs de Guerre 1915-1916-1917. Nice, Imprimerie, 1920.

Peaudelue, Lèon Aimé. Aux Dardenelles, A Lemnos. Nice, Impr. Du Patronage Saint Pierre, 1925.

Raymond, Ernest. The Story of My Days. London, Cassell, 1968. 
Repington, Charles a Court. The First World War, 1914-1918. 2 cilt, London, Constable, 1920.

Ribblesdale, Lord. Charles Lister: Letters and Recollections. New York, Charles Scribner's Sons, 1917.

Robertson, William. Soldiers and Statesmen, 1914-1919. 2 Vols.., London, Cassell, 1926.

Ross, Malcolm and Noel Ross. Light and Shade in War. London, Edward Arnold, 1916.

Roux, Charles. L'Expédition des Dardenelles. Paris, Armand Colin, 1920.

Roux, Charles Fr. Çanakkale Seferi, (Çev. Mehmet Nihat-Asım), İstanbul, Matbaa-i Askeriye, 1337 (1921).

Ruhl, Arthur. Antwerb to Gallipoli. New York, Charles Scribner's Sons, 1916.

Ruhl, E. J. Jacka's Mob. Angus and Robertson, 1933.

Samson, C. R. Fights and Flights. London, Ernest Benn, 1930.

Sanders, Liman Von. Fünf Jahre Türkei. Berlin, August Scherl, 1919.

Sanders, Limann Von. Five Years in Turkey, U.S. Naval Institute, Annapolis 1927.

Sanders, Limann Von. Türkiye'de 5 Yll, (Çev. M. Şevki Yazman) İstanbul, 1968.

Sarrail, Maurice P. Mon Commandement en Orient. Paris, Ernest Flammarion, 1920.

Sazonov, Serge. Fateful Years, 1906-1916. London, Jonathan Cape, 1928.

Selahattin Adil Paşa, Hayat Mücadeleleri. Selahattin Adil Paşa'nın Hatıraları. (Haz., Enver Koray), İstanbul, 1982.

Schuler, Philip. Australia in Arms. London, Fisher Unwin, 1916.

Sellers, Leonard. The Hood Battalion: Royal Naval Division: Antwerb, Gallipoli, France 1914-1918. London, Leo Cooper, 1995.

Silas, Ellis. Crusading at Anzac, Anno Domini, 1915. London, British Australian, 1916.

Simpson, C. R. History of Lincolnshire Regiment, 1914-1915. London, Medici Society, 1931.

Sparrow, Geoffrey, and J. N. MacBean Ross. On Four Fronts With the Royal Naval Division. London, Hodder and Stoughton, 1918.

Still, John. A Prisioner in Turkey. London, John Lane, The Bodley Head, 1920.

Stoker, H. G. Straws in the Wind. London, Herbert Jenkins, 1925.

Stuermer, H. Two Years in Constantinople, London, Hodder and Stoughton, 1917.

Talât Paşa'nın Hatıraları, (Yay. Enver Bolayır) ,İstanbul,1958.

Thomson, Alistar, Anzac Memoirs. Living with the Legend. New York, 1995.

Thomson, Alistair. Anzac Memoires. Melbourne, Oxford University Press, 1994. 
Thompson, C. W. Records of the Dorset Yeomanry (Queen's Own), 1914-1919. Sherborne, F. Bennet \& Co., The Parade, 1921.

Throssel, Ric. My Fatherís Son. Melbourne, William Heineman, 1989.

Tilton, Mary. The Great Battalion. Sydney, Angus and Robertson, 1933.

Tisdall, Arthur Walderne St. Clair. Verses, Letters and Remembrances of Arthur Walderne St. Clair Tisdall. London, Sidgwick and Jackson, 1916.

Trooper Bluegum [Hogue, Oliver]. Love Letters of Anzac. London, Andrew Melrose, 1916.

Troubridge, Laura. Memoires and Reflections. London, William Heinemann, 1925.

Tubby, A. H. A Consulting Surgeon in the Near East. London, Chiristophers, 1920.

Tuğrul, Afif. Bizim Harbimiz. İstanbul, T.C. Deniz Basımevi, 1956.

Tunççapa, Şakir. Çanakkale Harbi Hatıralarım. İstanbul, Deniz Basımevi, 1958.

Türkgeldi, Ali Fuad. Görüp Işittiklerim. 3.bs., Ankara, T.T.K. Basımevi, 1951.

Uluaslan, Hüseyin - Salih, Zeki. 18 Mart 1915 Çanakkale Zaferi Hatırası. İstanbul, 1981.

Us, Asım. Gördükleri, Duyduklarım, Duygularım. İstanbul, Vakit matbaası, 1964.

Usborne, C. V. Smoke on the Horizon: Mediterranean Fighting, 1914-1918. London, Hodder and Stoughton, 1933.

Vassal, Joseph. Uncensored Letters From the Dardenelles, Written to His English Wife by a French Medical Officer of L'Corps Exp⿳亠㐅冋ditionnaire d'Orient. London, William Heinemann, 1916.

Yetkin, Gıyas. Yaratanların Ağzından 18 Mart 1915 Çanakkale Zaferi. Ankara, Genkur. Basımevi, 1966.

Warner, Oliver. Admiral of the Fleet: Cunningham of Hynhope. Athens, Ohio University Press, 1967.

Watkins, Charles. Lost Endeavur. Privetely Printed, 1971.

Weaver, Lawrence. The Story of the Royal Scots. London, Country Life and George Newnes, n.d.

Webster, F. A. M. The History of the Fifth Battalion: The Bedfordshire and Hertfordshire Regiment (T. A.). London, Frederick Warne, 1930.

Wedgwood, Josiah Clement. With Machina Guns in Gallipoli. London, Darling and Son, 1915.

Wedgwood, Josiah Clement. Essays and Adventures. London, Allen and Unwin, 1924.

Welborn, Suzanne. Lords of Death: A People, A Plece, A Legend. Fremantle, Fremantle Arts Centre Press, 1982.

Weldon, L. B. “Hard Lying;" Eastern Meditarranen, 1914-1919. London, Jenkins, 1925 . 
Williams, H. R. The Gallant Company: An Australian Soldierís Story of 1915-1918. Sydney, Angus and Robertson, 1933.

Wilkie, A. H. Official War History of the Wellington Mounted Rifles Regiment 1914-1919. Wellington, Whitcombe and Tombs, 1924.

Wilkinson, Norman. The Dardenelles: Colour Sketches From Gallipoli. London, Long-mans, Green, 1915.

Wylly, H. C. Neillís "Blue Caps." 3 Vols. Aldershot, Gale and Polden, (t.y)

Wyrall, Everard. The Die-Hards in the Great War: A A History of Duke of Cambridge's Own (Middlesex Regiment) 1914-1919. 2 Vols. London, Harrison and Sons, 1926-1930.

Wyrall, Everard. The East Yorkshire Regiment in the Great War, 1914-1918. London, Harrison, 1928.

Wyrall, Everard. The Gloucestershire Regiment in the Great War, 1914-1918. London, Methuen, 1931.

Wyrall, Everard. The West Yorkshire Regiment in the Great War 1914-1918. 2 Vols. London, John Lane The Bodley Head, (t.y).

\section{TEZLER}

Avcı, Sinan. Çanakkale Savaşlarında Alman Askeri Heyeti ve Yardımları. Çanakkale 18 Mart Üniversitesi, 1997. (Yüksek Lisans Tezi)

Çakır, Ömer. Nazmımızda Çanakkale Muharebeleri. Gazi Üniversitesi, 1997. (Yüksek Lisans Tezi)

Eryılmaz, Esin. Çanakkale Savaşları. Trakya Üniversitesi, 1997. (Yüksek Lisans Tezi)

Göçer, Sami. Ístanbul Kütüphanelerinde Çanakkale Muharebelerinin Edebiyata Yansıması İl e İlgili Eserler. Trakya Üniversitesi, 1992. (Yüksek Lisans Tezi)

Hutcheson, John A., Jr. From Constantinople to Coalition: British Press Reaction to the Dardenelles Campaign and the Fall of the Liberal Government. University of North Carolina, 1968. (Yüksek Lisans Tezi)

Skaggs, Glenn Eugene. Britain at the Straits: A Study of British Diplomacy Towards the Turkish Straits, 1900-1923. Georgetown University, 1963. (Doktora Tezi)

Smith, Michael Doglas. Britain, Russia, the Gallipoli Campaign and the Straits. Florida State University, 1979. (Doktora Tezi)

Stokesbury, James. British Concepts and Practices of Amphibious Warfare, 18671916. Duke University, 1968. (Doktora Tezi)

Uluksar, Emin Gündüz. Çanakkale Zaferi ve Atatürk'ün Rolü. İstanbul Üniversitesi, 1996. (Yüksek Lisans Tezi)

Yazan, Mehmet Ali. Birinci Dünya Savaşı Basınında Çanakkale Muharebeleri. Sakarya Üniversitesi, 1996. (Yüksek Lisans Tezi) 
Yılmaz, Celal. Çanakkale Savaşlart ve Türk Ordusu. Gazi Üniversitesi, Ankara, 1999. (Doktora Tezi)

Yılmaz, Veli. I. Dünya Harbi'nde Türk-Alman Ittifakı ve Askeri Yardımlar. Ankara Üniversitesi, 1988. (Doktora Tezi)

\section{BİBLIYOGRAFYALAR}

Dış Basında Çanakkale Savaşlarının 75. Yıldönümü (22 Şubat-26 Nisan 1990), Ankara, Başbakanlık Basın Yayın ve Enformasyon Genel Müdürlüğü Yayınları, 1990.

Enser, A. G. S. A Subject Bibliography of the First World War: Books in English 1914-1987. 2.nd. ed., Bookfield. VT: Gower, 1990; orig. 1979.

Falls, Cyril. War Books: A Critical Guide. London, Peter Davies, 1930-1989.

First World War; Gallipoli campaign a catalog of books available at the library. London, Imperial War Museum Library, 1951.

Hartesveldt, Fred R. Van. The Dardenelles Campaign, 1915. Historiography and Annotated Bibliography. London, Greenwood Press, 1997.

White, A. S. A Bibliography of Regimental Histories of the British Army. London, Society for Army Historical Research in Conjunction With the Army Museum's Ogilby, 1965.

Yıldırım, Hüseyin, Çanakkale Savaşları Bibliyografyası, Çanakkale Savaşları 80. Yıl Armağanı , Ankara, Genkur. Bşk., Deniz Kuvvetleri Komutanlığı, 1995.

Yücel, Prof. Dr. Yaşar. "Birinci Dünya Harbi Tarihi Bibliyografyası" Askeri Tarih Belgeleri Dergisi Y. 11, S.20 (Şubat 1986) s. 157-174.

Yücel, Yaşar "Türkei: Bibliography of the First World War." Neue Forschungen zum Ersten Weltkrieg: Literatur beichte und Bibliographen (Haz., Jürgen Rohwer) Koblenz Bernard and Greate, 1985.

\section{MAKALELER}

A. Haydar Emir. "Çanakkale Zaferi'nde Türk Bahriyesi" Risale-i Mevkute- $i$ Bahriye, C.7, S.7 (Nisan 1340) s.1713-1753.

Acar, Nilgün. “18 Mart'ın Getirdikleri”, Kemalizm, C. 16, S. 176 (Mart 1973) s.10.

Ağca, Yrd. Doç. Dr. Hüseyin. "Tarihte Liderlik ve Çanakkale Zaferinde Liderler" Atatürk Araştırma Merkezi Dergisi, C.10, S. 30 (Kasım 1994) s.569-597.

Ağralı, Sedat. “Çanakkale Geçilmez”, Kemalizm, C.7, S. 80 (Mart 1969) s.4-6.

Akat, Aral, "Mehmetcik ve Çanakkale", Silahlı Kuvvetler Dergisi, C.116, S. 352 (Nisan 1997) s. 73-78.

Akbay, Cemal, “Çanakkale Cephesi Arıburnu Bölgesinde 19 ncı Tümen’in 25/26 Nisan Gecesi Taarruzu” Çanakkale Muharebeleri 75 nci Yıl Armă̆anı, Ankara, Genkur. Bşk., 1990, s.91-98. 
Akbay, Cemal, "Birinci Dünya Harbinde İngiliz Donanması, İstanbul Önüne Gelebilseydi Osmanlı İmparatorluğu'nun Harbe Devamı, Birinci Dünya Harbi'nin Genel Durumu Üzerinde Ne Gibi Bir Etki Yapardı ?", Askeri Tarih Belgeleri, C.14-15, S. 27 (1990) s.105-118.

Akçora, Ergünöz, "Çeşitli Yönleriyle Çanakkale Muharebeleri”, Türk Dünyası Tarih Dergisi, C.8, S. 88 (Nisan 1994), s. 15-28.

Akçora, Ergünöz. “Çanakkale Savaşı'nda En Uzun Gün 18 Mart 1915”, Türk Dünyası Tarih Dergisi, C.2, S. 15 ( Mart 1988), s. 14-27.

Akgül, Nilgün, "Çanakkale Muharebeleri ve Etkileri”, Askeri Tarih Belgeleri, C.16, S.31, (Ağustos 1991), s.65-74.

Akgül, Suat, "Çanakkale Muharebelerinin Askeri ve Siyasi Sonuçları", Ayyıldız Aylık Fikir-Kültür ve Sanat Dergisi, C.5, S. 41 (Mart 1998), s.14-16.

Akgün, Seçil, "Çanakkale Savaşları", Tarih Çevresi, S.9, (Mart-Nisan 1994), s. 2025.

Akkaya, İbrahim (Gü. Alb.). "Paylaşılamayan Zafer ve Bazı Gerçekler”, Deniz Kuvvetleri Dergisi, C.90, S. 502 ( Temmuz 1978) s. 34-37.

Aktar, Yücel (Dr.). “Çanakkale Muharebeleri”, Silahlı Kuvvetler Dergisi,. 107/314 (Mart 1988) s.59-69.

Akyüz, Yahya, "Çanakkale Savaşları ve Fransız Kamuoyu”, Çanakkale Savaşları, Sebep ve Sonuçları Uluslararası Sempozyumu, Ankara, T.T.K., 1993, s. 121124.

Alpagut, Ali Haydar Emir. "Akdeniz Boğazı Muharebeleri”, Risale-i Mevkute- $i$ Bahriye, C.1, S. 8,11,12; C. 2, S. 2,4,6,8,10 (1331-1332)

Alpagut, Ali Haydar Emir. "Çanakkale Zaferinde Türk Bahriyesi", Risale-i Mevkute-i Bahriye, C.7, S. 2 ( 1340) s.

Altay, Fahrettin, "Çanakkale Savaşlarının İlk Günlerinde Mustafa Kemal (Atatürk)", Belleten, C. XX, S. 80 (Ekim 1956), s.605-607.

Apatay, Çetinkaya. "Çanakakle Muharebelerinde Denizaltı Harekatı", Belgelerle Türk Tarihi Dergisi, S.27 (Mart 1988) s. 51-58.

Apatay, Çetinkaya. "Neden Çanakkale?" Deniz Kuvvetleri Dergisi, C.96, S. 509 (Nisan 1980) s.39-43

Arda, Yusuf. "Birinci Dünya Savaşı'nda Türk Denizcilerinin Karadeniz, Marmara ve Ege Denizi'nde Savaşları” Süvari Dergisi, S. 150-151 (Temmuz/Ekim 1952) s. 45-47.

Arıkan, Zeki, “Yeni Gün'ün Müsabakası'nda Mustafa Kemal Paşa”, Atatürk Yolu, C.3 S. 11 (Mayıs 1993), s.243-258.

Armaoğlu, Fahir, “Çanakkale Muharebelerinin Rusya Üzerindeki Etkileri”, Çanakkale Savaşları, Sebep ve Sonuçları Uluslararası Sempozyumu, Ankara, T.T.K., 1993, s.7-29. 
Arslan, Esat (Dr.). "Çanakkale'de Günceller Işı̆̆ında Cephenin İki Tarafı", S.K.D., C.116, S.352 (Nisan 1997) s. 31-50.

Atak, Sadık. "18 Mart Çanakkale Zaferinin 60. Yıl Dönümü”, Hava Kuvvetleri Dergisi, C.53, S. 254 (Mart 1975) s.76-80.

Atakan, Rauf, "Birinci Dünya Harbi'nde Türk Harbi Çanakkale Muharebeleri İdari Faaliyet ve Lojistik", Çanakkale Muharebeleri 75 nci Yıl Armağanı, Ankara, Genkur Bşk., 1990, s. 141-145.

Avcı, Cemal, “Çanakkale Savaşı'nın Sonuçları ve Milli Mücadele’ye Etkileri”, Atatürk Araştırma Merkezi Dergisi, Çanakkale Zaferi'nin 80. Yıldönümü. C.10, S. 30 (Kasım 1994), s.717-719.

Aybars, Ergün, "Çanakkale Zaferinin Siyasi Sonuçları”, Dokuz Eylül Üniversitesi Çarşamba Konferanslarl, 1986-1987, İzmir, Dokuz Eylül Üniversitesi, 1987, s. 253-270.

Aytepe, Oğuz. "Çanakkale ve Mustafa Kemal”, Anıtkabir. S.2 (Nisan 2000) s.40-43.

Bardakçı, İlhan. "Osmanlı'nın Son Zaferi” Çanakkale Tarih ve Medeniyet Dergisi, S. 2 (Nisan 1984) s. 9

Bargut, Şemsi. "Deniz Müstahkem Mevkileri Hakkında Bir Etüt”, Donanma Dergisi, C.67, S.412 (Ocak 1956) s.21-28.

Başaran, Selami, "Çanakkale Muharebesi Kara harekatına Genel Bir Bakış", Çanakkale Muharebeleri 75 nci Yıl Armă̆anı, Ankara, Genkur. Bşk., 1990, s. 73-80.

Başaran, Selami, "Çanakkale Muharebesinin Nedenleri, Deniz ve Kara Harekatına Genel Bir Bakış", ODTÜ 30. Kuruluş Yıldönümü "Çanakkale Savașları'nın Askeri ve Siyasi Yönü” Sempozyumu Bildirileri, Ankara, Orta Doğu Teknik Üniversitesi, 1987, s.73-80.

Baubnof, Alexandre. "Büyük Harp Esnasında İstanbul Boğazı Meselesi”, (Çev. Muhittin Etingü) Deniz Mecmuast, C. 48, S. 340 (1936) s. 200-217.

Bayazıd, Taner (Öğ. Yzb.). "Boğazlar ve Çanakkale Cephesi” Silahl Kuvvetler Dergisi, S. 92/248 (Aralık 1973) s.86-91.

Baycan, Nusret. "Karadeniz Olayı ve I. Dünya Harbine Girişimiz" Atatürk Araştırma Merkezi Dergisi, C.8, S.22 (1992) s.175-182.

Bayrak, Rıfat, "İlk Hava Zaferimiz”, Uçantürk, C.42, S. 408 (Mayıs 1996), s. 41.

Bayraktar, Fazıl, "Kendi Hatıralanı İle Çanakkale Savaşı", Türk Edebiyatı, C.26, S. 294 (Nisan 1998), s. 18-20.

Bayur, Yusuf Hikmet. "Çanakkale Savaşı ve 18 Mart 1915 Zaferi” Çanakkale 18 Mart 1915-1950. Ankara, T.T.K. Basımevi, 1950, s.12-15.

Bayülken, Oktay. "Çanakkale Muharebelerinde Kaymakam (Kurmay Yarbay) Mustafa Kemal Bey (Atatürk) ve Mehmetçik" T.C. I.Ü. Atatürk İlkeleri ve Inkılap Tarihi Enstitüsü Yıllı̆̆ı, III. 1988, İstanbul, 1988, s.89-116.

Belen, Fahri. “ Mustafa Kemal Çanakkale'de” Kemalizm, S.6 (68), (Mart 1968) s.48 . 
Berker, Şevki. "Çanakkale'de Türk Zaferi”, Kudret Gazetesi, C. 6, S. 1507 (Mart 1952) s.2.

Berköz, Nuri. “Çanakkale Zaferi”, Ulus Gazetesi, C.32, S. 11036, (18. Mart.1952) s.2.

Besbelli, Saim. "Tarih Yapan Gemi: Yavuz” Derya, S. 70 (1973) s. 10-11.

Besbelli, Saim. "Çanakkale'de Türk Bahriyesi” S. 424, İstanbul, 1959 (Donanma Dergisi Eki)

Besbelli, Saim. "Çanakkale Zaferimiz 57 Yaşında”, Belgelerle Türk Tarihi Dergisi, C. 9, S.53 (Şubat 1972) s.15- 17.

Besbelli, Saim. "Çanakkale", Silahlı Kuvvetler Dergisi, S.9/241, (Mart 1972) s.5256.

Besbelli, Saim. “1915 Şubatı'nda Türk Deniz Kuvvetleri Ne Yapıyordu ?” Derya , S. $65,(1973)$ s.6-7.

Besbelli, Saim. "1915 Çanakkale'sinde Türk Bahriyesi”, Derya, S.42 (1971) s.1213.

Besbelli, Saim. "18 Mart 1915" Derya, S.92 (1975) s.4.

Besbelli, Saim. "1909-1919 İlk Donanma Cemiyetinin Yardımıyla Sağlanan Harp Gemileri: Reşadiye, I. Sultan Osman, Fatih Muharebe Gemileri” Derya, S.52 (1971) s.17.

Besbelli, Saim. "Nusret", Derya, S.54 (1972) s.24-26.

Besbelli, Saim. "Yavuz, Tarih Yapan ve Tarih Açan Gemi", Belgelerle Türk Tarihi Dergisi, C.9, S. 52 (Ocak 1952) s. 17-19.

Beyoğlu, Süleyman. “Kralın Adamları'na Ne Oldu?”, Popüler Tarih, S. 1 (Haziran 2000) s. 38-43

Bodger, Alan. "Russia and the End of the Ottaman Empire", (Ed. Marian Kent), The Great Powers and the End of of the Ottaman Empire. Londra, George Allen and Unwin, 1984

Bolay, Süleymen, Hayri, “Çanakkale Zaferinde Manevi Gücün Rolü”, Atatürk Araştırma Merkezi Dergisi, C.10,S.30 (Kasım 1994), s. 553-557.

Bozdağ, İsmet, "Osmanlının Son Şehnamesi: Çanakkale: Orada Dünyanın En Güçlü Devletlerini Dize Getirmiştik" Tarih ve Medeniyet, C.2, S. 25 (Mart 1996), s. 109-117.

Büyükdeğirmenci, İbrahim."Çanakkale Zaferinin Türk Tarihi Bakımından Önemi”, Silahll Kuvvetler Dergisi, S. 90 (237), (Mart 1971) s. 42-47.

Büyüktuğrul, Afif. "Çanakkale'de Türk Bahriyesi” Risale-i Mevkute-i Bahriye, C.9, S. 5 (1926).

Büyüktuğrul, Afif. "Tarih Akışını Değiştiren Muhteşem Şanlı Destan (Çanakkale Zaferi Üzerine)”, Kemalizm, C. 25, S. 284 (Mart 1986) s. 1-4.

Büyüktuğrul, Afif. "Çanakkale Savaşı", Kemalizm, C.25, S.276 (1987) s.5-7. 
Büyüktuğrul, Afif. "18 Mart Deniz Zaferi ve Avrupa Tarihi”, Atatürk Türkiyesi, S.68-70, (1981) s.31-33.

Büyüktuğrul, Afif. "Çanakkale'de Destanlar Yaratan Nusret Mayın Gemisi” Kemalizm, S.224 (Mart 1981) s.13-17.

Carus, Serdar. "Kurtuluş Savaşını Hazırlayan Yönü İle Çanakkale savaşı" T.C. A.I Atatürk İlkeleri ve İnkılap Tarihi Enstitüsü Yıllı̆̆ı, IX. (1994-1996), İstanbul, Çantay Kitabevi, s.19-26.

Cebesoy, General Ali Fuat. "Büyük Harpte Osmanlı İmparatorluğu 1916 Yılında Durum”, Belgelerle Türk tarihi Dergisi, S.24 (Ocak 1999), s 77-80

Cumbur, Müjgan, “Çanakkale'nin Üç Gazisi: Süleymen Paşa, Yakup Ece ve Gazi Fazıl”, Ayylldiz Ayllk Fikir-Kültür ve Sanat Dergisi, C.3, S. 19 (Mayıs 1996), s. $12-14$.

Çakır, Ömer. "Çanakkale Muharebelerinin Türk Şiirindeki Yeri ve Önemi Üzerine Bir Tasnif Denemesi" Atatürk Araştırma Merkezi Dergisi, C. 12 , S. 34 (Mart 1996) s.331-338.

"Çanakkale Muharebeleri”, (Çev. Bnb. Necati) Deniz Mecmuası, C. 46, S. 334 (Birinci Teşrin 1934) s. 421-435.

"Çanakkale Muharebeleriyle İlgili Menkıbeler", Çanakkale Muharebelerinin 75 nci Yıl Armağanı, Ankara, Genkur. Bşk., 1990, s. 181-188.

"Çanakkale Savaşı", Birinci Dünya Savaşı Ansiklopedisi, C.7 , İstanbul, 1976.

“Çanakkale Seferi”, Türk Ansiklopedisi, C. 11. s. 356-366.

"Çanakkale'de 253 bin Değil 57 bin Şehit Verdik: Asrın Hatası", Milliyet, (18812), 19 Mart 2000, s.1, 17.

"Çanakkale'de Destanlar Yaratan Nusret Mayın Gemisi”, Kemalizm, S. 244, (1981) s.13-17.

“Çanakkale'de Türk Bahriyesi”, Donanma Dergisi, C.71, S. 424 (Ocak 1959) s.40.

Çaycı, Abdurrahman, "Çanakkale ve Gelibolu Yarımadasının Atatürk'ün Askeri Kariyerindeki Yeri”, Çanakkale Savaşları Sebep ve Sonuçları Uluslararası Sempozyumu, Ankara, T.T.K Basımevi, 1993, s. 55-68.

Çaycı, Prof. Dr. Abdurrahman. "Türk Ordusunun Çanakkale Zaferi ve Siyasi Neticeleri” Türk Kültürü Araşttrmaları, S. 58 (ağustos 1967) s.719-727.

Çekmeceligil, Ömer. "Çanakkale Savaşları ve Donanma Cemyeti'nin Katkısı", Derya, S. 172 (1986) s.11-21.

Çekmeceligil, Ömer. "Çanakkale Zaferi", Deniz Kuvvetleri Dergisi, S.540, (Nisan 1988) s.60-69.

Çelik, Birten. "İzmir Basınında Çanakkale Muharebeleri ve Cephe Gerisi”, Askeri Tarih Semineri, V-II. (23-25 Ekim 1995/İstanbul) s.423-437.

Çeliker, Fahri."Çanakkale ve Mustafa Kemal" Atatürk Araştırma Merkezi Dergisi, C. 3 , S. 9 (1987) s.635-655 
Çeliker, H. Fahri, "Çanakkale Muharebeleri ve Atatürk", Atatürk Araştırma Merkezi Dergisi, C.10, S. 30 (Kasım 1994), s. 685-694.

Çeliker, Fahri. "Turkey in the First World War." Revue d'Histoire militaire, (1980), s164-203.

Çeliker, Fahri. “18 Mart Zaferi”, Atatürk Araştırma Merkezi Dergisi, C. 4, S. 12 (1988) s.651-663.

Çetinoğlu, Neşe. “Tarihi Bir Dönüm Noktası: Çanakkale Zaferi”, Atatürk Araştırma Merkezi Dergisi, C.10, S. 30 (Kasım 1994), s. 725-727.

Çetinöz, H. Fehmi. "İstanbul ve Çanakkale Boğazları" Ülkücü Öğretmen, C.11, S. 132 (Mayıs 1970) s. 11-12.

Çoker, Fahri. "Çanakkale 1915 İçin Zorunlu Bir Açıklama” Deniz Kuvvetleri Dergisi, S.560, (Temmuz 1994) s.79-80.

Darkot, Besim, “Çanakkale Muharebeleri” İslam Ansiklopedisi, C. III., s.347-351.

D'Amade, Albert, "Constantinople et les détrois", Revue des questions historiques, (Ocak-Şubat 1923).

Denizli, Ali, “18 Mart 1915 Çanakkale Zaferi, 19 ncu Tümen ve Anafartalar Grup Komutanı Atatürk”, Silahll Kuvvetler Dergisi, C.115, S. 348 (Nisan 1996), s. 1522.

Denman, Terry. "The $10^{\text {th }}$ (Irish) Division 1914-15: A Study in Military and Political Interaction.” Irish Sword, S. 17 (1987), s. 16-25.

Doğanay, Rahmi, “Çanakkale Zaferinin Türk ve Dünya Tarihi Açısından Sonuçları”, Atatürk Yolu, C. 3, S. 12 (Kasım 1993), s. 363-371.

Dokur, Aydın. "I. Dünya Savaşı'nın Dönüm Noktası", Hayat Tarih Mecmuası, C.2, S.12 (Ocak 1969), s.64-67.

Duran, Mehmet, “26 Demir Kap”, Çanakkale Muharebeleri 75 nci Yıl Armağanı, Ankara, Genkur. Bşk., 1990, s.107-108.

Duran, Tülay, “18 Mart 1915 Çanakkale Zaferi'nin Yildönümü”, Belgelerle Türk Tarihi Dergisi, S. 38 (Mart 2000), s. 7-16.

Dümer, Ziya Vehbi. "Çanakkale Muhaberatında İngiliz Denizaltı Gemilerinin Aldığı Vazifeler ve Bahriyemizin Bu Gemilerle Mücadelesi", Deniz Mecmuast, C.46, S.334 (1934) s.585-615.

Dümer, Dz. Yzb. Ziya Vehbi. "Çanakkale Savaşlarında Türk Bahriyesi” Deniz Mecmuast, C.47, S.336 (1935) s.313-336.

Edinburg, Duke (Philip) of. "Ends and Means" Army Quarterly and Defense Journal, S. 117 (1987), s. 263-275.

Ekinci, Yusuf. “Çanakkale Deniz Zaferi” Karınca, C.55, S. 627 (1989) s.29-31.

Ekstein, Michael G. "Russia, Constantinople and the Straits." British Foreign Policy Under Sir Edward Grey. (Ed. F. H. Hinsley), Cambridge, Cambridge University Press, 1977. 
Elald1, Kr. Yzb. Muzaffer. “Çanakkale'yi Tarihe Maledenler”, Donanma Dergisi, C.75, S.438 (Temmuz 1962) s.9-17.

Enginün, İnci. “Çanakkale Zaferi'nin Edebiyata Aksi”, Türklük Araştırma Dergisi, İstanbul, 1987 (Ayrı Basım).

Ercan, Tevfik, "Seddülbahir Çıkarmasında 26 ncı Alay 3 ncü Tabur", Çanakkale Muharebeleri 75 nci Yıl Armağanı, Ankara, Genkur. Bşk., 1990, s. 99-106.

Eren, Mehmet Ali, “Avustralya Resmi Savaş Muhabirinin Dehşet Dolu İtirafları; Türkleri Diri Diri Yaktık”, Aksiyon, C.5, S.223 (13-19 Mart 1999) s.32-39.

Ergin, Sabahattin. "18 Mart Çanakkale Zaferi” T.C. A.I Atatürk İlkeleri vw Inkılap Tarihi Enstitüsü Yıllı̆̆ı, IX. (1994-1996), İstanbul, Çantay Kitabevi, s.93-98.

Erilkun, Burhan. "18 Mart Çanakkale Zaferi ve Tarihin Akışına Tesirleri” Vatan Gazetesi, C.12, S.3895 (19.3.1952) s.5.

Erkal, Şükrü, “Birinci Dünya Savaşı'nda Çanakkale Cephesi Deniz Harekatı (Boğazın Zorlanması)", Çanakkale Muharebeleri 75 nci Yıl Armağanı. Ankara, Genkur. Bşk., 1990, s.35-72.

Erkman, Ö. - Kunt, T. "Çanakkale Zaferi” Deniz Kuvvetleri Dergisi, C. 80, S.485 (Nisan 1974) s.3-9.

Ersel, Hasan. "Yavuz Geliyor Yavuz” Toplumsal Tarih, S. (Nisan 2000) s.28-39.

Es, Hikmet Feridun. "Avustralya'da Çanakkale", Hayat Tarih Mecmuası, C.1,S.5 (Haziran 1967), s.10-15.

Esat Paşa. "Çanakkale Hatıraları”, Hayat Tarih Mecmuası, C.2, S. $27-41$ (1959)

Evans, Raymond. "The Anzac Story: Myt and Reality" History Teacher:The Nagazine Of the Queensland History Teachers Association. S. 21 (1983), s. 1013.

"First Turkish Reinforcements at Suvla, August $7^{\text {th }}-9^{\text {th }} 1915$, The" The Army Quarterly S. 19 (1929-1930), s. 92-103.

Florinsky, M. T. "A Page of Diplomatic History: Russian Military Leaders and the Problem of Constantinople During the War", Political Science Quarterly, S. 44 (March 1929) s.105-115.

French, David. "The Origins of the Dardenelles Campaign Reconsidered", History, S.68 (1983), s. 210-24.

Fuat, Sermet. "Cihan harbinde Türk Filosu”, Deniz Mecmuası, C.45, S. 328 (1933) s.100-126.

Güngen, Coşkun. "Çanakkale Zaferi ve Düşündürdükleri”, Deniz Kuvvetleri Dergis, C. 19 S.546 (Mart 1990) s.44-48.

Gürer, C.[evad] A.[bbas], “Atatürk Çanakkale'de”, Tarih-Coğrafya Dünyası, S. .2, s. 187.

Gürsal, Erkan. "Çanakkale Savaşı'nda Türk Denizcileri”, Kemalizm, S.320 (Mart 1989) s.5-10. 
Güzel, Abdurrahman. "Nara Kalesi - Çanakkale” Türk Kültürü, C. 24, S. 276 (Nisan 1986) s. 270.

Güzel, Abdurrahman, "Türk Edebiyetında Çanakkale Savaşları ve Zaferi İle İlgili Menkıbe, Destan, Şiir, Anekdot ve Efsaneler", Türk Kültürü, C.35, S. 409 (Mayis 1997), s.268-285.

Güzel, Abdurrahman, “Onsekiz Mart 1995 Çanakkale Zaferinin 80. Yılında Milli Birlik ve Beraberlik", Atatürk Araştırma Merkezi Dergisi, C.10, S. 30 (Kasım 1994) s. 535-540.

Hızal, Şamil. "Çanakkale Önünde ve Marmara'da Denizaltılar” Deniz Kuvvetleri Dergisi, S.539, (Ocak 1988) s. 52-60.

Hill, J. G. "The Dardenelles campaign-lost opportunities an allied perspective", Çanakkale Savaşları Sebep ve Sonuçlart Uluslararası Sempozyumu, Ankara, T.T.K., 1993, s. 165-167.

Hiley, Nicholas. “ 'Enought Glory for All': Ellis Ashmead-Bartlett and Sir Ian Hamilton at The Dardenelles." Journal of Strategic Studies. S. 16 (1993) s. 240 264.

Hoover, Karl D. "Commander Otto Hersing and the Dardenelles Cruise of S.M.U. 21.” American Neptune. S. 36 (1976) s. 33-44.

Işık, Hüseyin. “İki Dünya Savaşı'nda Türk Boğazları”, Askeri Tarih Bülteni, C.10, S.18 (Şubat 1985) s. 1-8.

Işıksal, Turgut. "I. Dünya Savaşı Başlarken Rusya'nın Türkiye’ye Karşı Siyaseti” Belgelerle Türk Tarihi Dergisi, C.11, S. 61 (Ekim 1972) s.22-31.

İbrahim (Bnb) . "Seddülbahir'de Türklerin İlk Şanlı Müdafaası", Askeri Mecmua, S.63, (Kanunu-u Evvel 1926) s.38-52.

İdil, Alpaslan, "Çanakkale Savaşları ve Türklerin Başarısı” Kemalizm ve Türkiye, C.5, S. 53 (Temmuz 1980) s.10-11, 14-15.

İdil, Alpaslan. "Çanakkale Savaşları Nedeniyle İnsanlığın Sesi”, Kemalizm ve Türkiye, C.5, S.54 (Ağustos 1980) s.18-19.

İğdemir, Uluğ. “Atatürk'ün Anafartalar Grubu Komutanlığından İstifasına Dair Bazı Belgeler” Belleten. C. 32, S. 128 (Ekim 1968), s. 463-478.

İlgürel, Sevim- Kemalyeri, Mucip. "Çanakkale Ruhu Nasıl Doğdu ve Azerbaycan Savaşı (1917-18)" İ.U. Edebiyat Fakültesi Tarih Enstitüsü Dergisi, S.415 (197374) s.442-443.

İlhan, Suat, "Çanakkale Muharebeleri", Atatürk Araştırma Merkezi Dergisi, C. 10, S. 30 (Kasım 1994), s. 673-684.

İnam, Ö̆̆. Kd. Üstğm. Erberk. "Çanakkale Savaşları Nedeniyle İnsanlığın Sesi”, Kemalizm ve Türkiye, C. 180, S. 457 (Nisan 1967) s.4-5.

İnan, Ayşe Afet."Mustafa Kemal Çanakkale Savaşlarında" Sümerbank Atatürk Özel Saytsi, (1965) s.53.

İnce, Nilgün, “Anzak Gözüyle Türk Askeri ve Atatürk”, Atatürk Araştırma Merkezi Dergisi, C.10, S.30 (Kasım 1994) s.721-723. 
İnci, Tevfik. "Golyat'ın Batırılışı”, Resimli Tarih Mecmuası, S. 17 (1951) s. 723 726.

İnci, Tevfik. "Gelibolu Muharebesi”, Resimli Tarih Mecmuası, S. 63 (1955) s. 3697 3699.

Lowe, C. J. "Italy and the Balkans, 1914-1915." British Foreign Policy Under Sir Edward Grey. (Ed. F. H. Hinsley) Cambridge,Cambridge University Press, 1977.

Kerner, Robert J. "Russia, The Straits, and Constantinople, 1914-15." Journal of Modern History. S. 1 (September 1929) s.400-415.

Kırzıoğlu, M. Fahrettin. “Anafartalar Grubu Komutanı (Eylül 1915) ve İkinci Ordu Kumandan Vekili (Aralık 1916) Mustafa Kemal İmzalı Dört Belge”, Atatürk Devrimleri Enstitüsü Dergisi, C. 1, S. 1 (Temmuz 1978) s.10-22.

“Kireçtepe'de”, Silahlı Kuvvetler Dergisi, C..80, S.202 (Haziran 1962) s. 54-61.

Koca, Salim, “ Türk Tarihindeki Meydan Savaşları Arasında Çanakkale Savaşlarının Yeri ve Önemi” Türk Yurdu, C. 15, S. 91 (Mart 1995), s. 295-313.

Kocabaş, Süleymen. "Birinci Dünya Harbi’nde Boğazlar Meselesi” Askeri Tarih Belgeleri, C.20, S. 39 (Ağustos 1995) s.90-97.

Kodaman, Bayram, "Harp, Büyük Devletler Çanakkale Muharebeleri”, Atatürk Araştırma Merkezi Dergisi, C.10, S.30 (Kasım 1994), s. 547-551.

Komut, Ziya. "I. Cihan Harbi’nde Çanakkale ve Baltık Çıkarması ile II. Cihan Harbi'nde Şimali Afrika ve İtalya Çıkarmalarının Mukayesesi”, Askeri Mecmua, C.64, S.139 (Mart 1946) (139. Say1 Eki)

Konukçu, Enver, "Çanakkale Zaferinin Kamuoyundaki Akisleri”, Erciyes, Aylık Fikir ve Sanat Dergisi, C.16 ,S. 186 ( Haziran 1993) s. 1-5.

Koprama, Kazım Yaşar - Akdes Nimet Kurat. "Birinci Dünya Savaşı Sırasında Türkiye'de Bulunan Alman Generallerinin Raporları", Tarih Araştırma Dergisi, C.4, D. 6/7 (1966) s.539-546.

Koraltan, Oktay (Ulş. Öyzb.). “Çanakkale’de Doğan Güneş”, Silahlı Kuvvetler Dergisi, C.103, S.290 (Mart 1984) s.122-128.

Kozanoğlu, Fikri. “Gelibolu’ya Çıkarma Bugün Yapılsaydı” Askeri Mecmua, C.56, S.109 (Haziran 1938) s.501-506.

Köstüklü, Nuri. “Çanakkale'de Şehit Olan Burdurlular ve Milli Sorumluluklarımız" Atatürk Araştırma Merkezi Dergisi, C.15, S. 43 (Mart 1999) s.1.

Krause, Michael D., "Gallipoli - Chanakkale: Case Study of Operational Art", Çanakkale Savaşları Sebep ve Sonuçları Uluslararası Sempozyumu, Ankara, T.T.K., 1993, s.3

Macfie, A. L. "The Straits Question in the First World War, 1914-1918." Middle Eastern Studies. S. 19 (1983) s. 43-74.

MacMunn, George. "The Lines of Communication in the Dardenelles." Army Quarterly. S.20 (1930) s. 52-63. 
Mahmut (Bnb.). “Seddülbahir'de İlk İhraca Karşı Koyan Tabur Kumandanının Notları”, Askeri Mecmua, C.51, S. 90 (Eylül 1933) s.307-322.

Marshall, S. L. A. "Suvla Bay" Great Military Battles, (Ed.Cyrill Falls) Londra, George Weidenfield and Nicolson, 1964-1969.

Marshal, S. L. A. “ Suvla Bay”, Military Review. S. 43 (November 1963) s.60-68.

Maurice, Frederick. "The Eastern and Western Controversy." Contemporary Review. S.114 (1918) s.623-30.

Mehmet İzzet (Çev.). "Çanakkale'de Alman Bahriyesi” Risale-i Mevkute-i Bahriye, C. 9, S.4 (Mayıs 1926) s. 218-240.

Mehmed Nihad (Kaym.). "Büyük Harpte Çanakkale Seferi” Askeri Mecmua, C.46, S.70, (Eylül 1928) s.2-82.

Mehmet Tahir (Yzb). "Gelibolu Nasıl Tahliye Edildi” Risale-i Mevkute-i Bahriye, C.3, S.8 (Haziran 1333) s. 357-370.

Miles, Sherma. "Notes on the Dardenelles Campaign of 1915." Coast Artillery Journal. S.61 (Aralık 1924) s.506-521 : S. 62 ( Ocak-Şubat-Mart 1925) s.23-42; 119-43; 207-25.

Muammer (Kd. Yzb.). "Müttefikler Tarafından Çanakkale Üzerine İcra Edilen Sevkülceyşi Bahri”, Risale-i Mevkutei Bahriye, C.7, S. 2 (Nisan 1340) s.19121925.

"Muavenet-i Milliye Zırhlısının Goliath Zırhlısını Batırması" Derya, S. 3 (1967) s.12.

"Muavenet-i Milliye Muhribi” Derya, S.49 ( Ankara 1971) s. 15.

Murphy, H. W. "The Landings at Gallipoli If Carried Out Today." Army Quarterly. S. 32 (1936) s. 25-30.

Mustafa Şerif. "Harb-i Bahriden Alınan Malumat-1 Esasiye" Risale-i Mevkute-i Bahriye, C.5, S.9 (1335)

Mustafa Şerif. "Çanakkale Boğazı Önlerinde”" Risale-i Mevkute-i Bahriye, C.5, S. 12 (Teşrin-i Evvel 1335 [Ekim 1919]) s.1105-1116.

Mustafa Şerif. "Çanakkale Hücumunun Esbab-1 Akameti”, Risale-i Mevkute-i Bahriye, C.6, S. 8 (Haziran 1336 [1920]) s. 1509-1516.

Mustafa Şerif. "Çanakkale Hücumunun Esbab-1 Akameti” Risale-i Mevkute-i Bahriye", C.6, S.9 (Temmuz 1336) s.1521-1532.

Mustafa Şerif. "Çanakkale Hücumunun Esbab-1 Akameti” Risale-i Mevkute-i Bahriye, C.6, S.10 (Ağustos 1336) s.1569-1570.

Mühlman, Carl. "Die deutsche Militarmission in der Türkei." Wissen und Wehr. S. 19 (1938) s. 847-55.

Mütercimler Öğ.Bnb. Erol. "Çanakkale 1915” Deniz Kuvvetleri Dergisi, S. 559 (Mart 1994) s.50-64.

Mütercimler, Erol, “18 Mart'in Anlamı”, Cumhuriyet, S.25730 (18 Mart 1996) s.2. 
Necmeddin (Eh. Yzb.). "Çanakkale'de Kumkale Harekâtı”, Mecmua-i Askeriye, S.40/41 (Temmuz 1338) s. 1-8.

Neilson, Keith. "Kitchener: A Reputation Refurbished?" Canadian Journal of History. S. 15 (1980) s. 217-229.

Nejat (Em. Bnb.). “Çanakkale Muharebeleri”, Deniz Mecmuası, C. 47, S. 335 (İkinci Kanun 1935) s. 17-22.

Nelson, John E. "Irish Soldier in the Great War." Irish Sword S. 11 (1974) s.16379.

Nevinson, Henry W. "The Dardelles Landings.” English Review. (June 1929) s.65460 .

Nihat (Em. Korg.) (Çev.). “1914'ten 1916 Senesine Kadar Balkan ve Türkiye'de Büyük Harp” Askeri Mecmua, C. 52 , S.95 (Kânun-1 evvel 1934) (95. Sayının Tarih K1sm1)

Nizamettin. "Bahri Sefit'te Yavuz ve Midilli", Risale-i Mevkute-i Bahriye, C.8, S. 2 (1341) s.?

Nizamettin. "Karadenizde İlk Ateş" Risale-i Mevkute-i Bahriye, C.8, S. 3 (1341) s. s.?

Nohn, E. A. "Die Konzeption Des Grossen Belagerungskriges: Gedanken über Gallipoli 1915." Wehrwissenschaftliche rundschau. S. 9 ( 1959) s.239-53.

Nuza, Fehmi. "18 Mart 1915 Çanakkale Zaferinin Türk Harp Tarihi Açısından Değerlendirilmesi” Türk Kültürü Araştırmaları, C.22, S.249, (Ocak 1984) s.3435 .

Nuza, Fehmi. "Sayın Tarihçi Yılmaz Öztuna'nın 18 Mart 1915 Deniz Savaşına Dair Bir Yazısı Hakkında” Türk Kültürü Araştırmaları, C. 25, S. 290 (Haziran 1987) s.371-378 (47-54).

Olcaytu, Em. Tümg. Turhan, “18 Mart Çanakkale Zaferi’nin Tarihteki ve Ulusal Yaşantımızdaki Yeri”, Atatürk Araştırma Merkezi Dergisi, C.10, S. 30 (Kasım 1994), s. 609-661.

“18 Mart Çarpışması Nasıl Cereyan Etti?” Vatan Gazetesi, S. 3895 (13 Mart 1952) s. 6.

“18 Mart 1915 "Deniz, (Türk Ticaret Kaptan ve Makinistleri Cemiyeti’nin Meslek Mecmuaası) S.33 (1 Mart 1933) s. 1-9.

“18 Mart 1915 Çanakkale Zaferi’nin 61 nci Yıl Dönümünü Anarken Zaferin Ölümsüz Kahramanları Hasan Mevsuf'a Sesleniş" (Derleyen. Osman Ancın), Hava Kuvvetleri Dergisi C.55, S.261 (Mart 1977) s. 3-13.

“Onsekiz Mart Hareketinin 37. Yıldönümü Dolayısıyla Çanakkale Zaferi” Dünya Gazetesi, C.1, S. 18 (18 Mart 1952) s. 2.

“Onsekiz Mart Zaferi Donanma Cemiyeti’nin İftiharı” (Çev. Adnan Yalın) Deniz Kuvvetleri Dergisi, S.536 (Nisan 1987) s.60-61.

Omurtak, Salih v.d., "Atatürk", İslam Ansiklopedisi, 10 Cüz, İstanbul, 1979, s.719807. 
O'Neil, Robert. "For Want of Critics... The Tragedy of Gallipoli." Army Quarterly and Defense Journal. S. 121 (1991) s.69-83.

Onur, M. Naci, "Çanakkale Savaşları ve Ali Vahid'in Eseri”, Türk Dünyası Araştırmalart, S. 123 (Aralık 1999), s. 149-164.

Orgun, Selçuk. "Birinci Cihan Harbi'ne Ait Bir Hatıra", Donanma Dergisi, C.69, S. 417 (1957) s.28-40.

Orhon, Alpaslan. "Birinci Dünya Savaşı'nda Çanakkale Boğazı'na Karşı Saldırıların Nedenleri ve Saldırıların Başarılı Olup Olamayacağı Konusunda Düşünceler" Askeri Tarih Belgeleri, C.3, S.5 (Mart 1978) s. 25-40.

Orhon, Alpaslan. "Çanakkale Boğazı Muharebesi (18 Mart 1915)", Askeri Tarih Belgeleri, C. 5, S. 10 (1980) s. 59-88.

Orhon, Alpaslan. "Mustafa Kemal Atatürk Çanakkale'de (25 Nisan 1915 Tarihine Kadar)" Askeri Tarih Belgeleri, C.7, S. 14 (Ağustos 1982) s. 1-16.

Ökse, Necati. "Atatürk Çanakkale'de” Silahlı Kuvvetler Dergisi, C.100, S. 277 (Mart 1981) s.82-88.

Ökse, Necati. "Bir Kahramanlık Destanı İle Bir Asalet Örneği”, A.H.A., 10 Kasım 1981, Ankara, Genkur. Askeri Tarih ve Stretejik Etüt Bşk., 1981, s.39-49.

Ökse, Necati. “Çanakkale Muharebeleri. Bu Muharebelerde Atatürk'ün Oynadığı Rol”, A.H.A., (10 Kasim1986), s. 107-132.

Ökse, Necati. "Atatürk in the Dardenelles Campaign." Revue Internationale Militaire. (1981) s. 167-183.

Ömer Vasfi (Yzb.Op.Dr.). "Çanakkale Savaşlarında Maydos Bombardımanı”, Hayat Tarih Mecmuası, C.1, S.2 (Mart 1967), s.19-23.

Öndeş, Osman. "Çanakkale ve Gelibolu Savaşları", Belgelerle Türk Tarihi Dergisi, C.9, S.53 (Şubat 1972) s.8-14.

Öndeş, Osman. "Deniz Savaşları (I. Dünya Savaşı)” Hayat Tarih Mecmuası, C.1, S. 6 (Haziran 1974 ) s. 56-60.

Örses, İclal. "Çanakkale ve Mustafa Kemal Atatürk Hakkında Farklı Bir Yanıt" Silahl Kuvvetler Degisi, 113, S. 340 (Nisan 1994), s. 71-77.

Özdoğan, Talat, “Çanakkale'de Türk Kahramanlığı”, Çanakkale Muharebelerinin 75 nci Yıl Armağanı, Ankara, Genkur. Bşk., 1990, s.155-168.

Özgil, İhsan. “Çanakkale Savşı’nda Seddülbahir Kıyılarının İlk Şanlı Müdafaası”, Askeri Mecmua, C. 56, S. 110 (Eylül 1938) s.659-661.

Özkan, Hülya, “Osmanlı İmparatorluğu'nun Birinci Dünya Savaşı'na Girişi ve Bu Savaş İçinde Çanakkale Muharebelerinin Önemi”, Askeri Tarih Belgeleri, C.17, S. 32 (Şubat 1992), s. 107-117.

Özkaya, Yücel. “Türk ve Dünya Basınında Çanakkale Savaşları”, Atatürk Araştırma Merkezi Dergisi, C.12, S. 34, (Mart 1996), s. 295-313.

Özkul, A. Rıza. "Kaymakam Mustafa Kemal ve Arıburnu”, Belleten, C.20, S.80, (1956) s.609-617. 
Özselçuk, Nusret."Çanakkale Muharebeleri'nin 75. Yıl Dönümünde Boğazlar ve Çanakkale Muharebelerine Genel Bir Bakış", Silahlı Kuvvetler Dergisi, C.109, S. 325, (Mayis 1990) s. 5-14.

Öztuna, Yılmaz. "Bir Kahraman Dört Destan", Hayat Tarih Mecmuası, C.1, S.2 (Mart 1969) s.9-17.

Öztuna, Yılmaz. “Çanakkale'nin Ünlü Kumandanlarından Esat Paşa” Hayat Tarih Mecmuast, C.1, S. 3 (Nisan 1965), s.19-22.

Öztürk, Yrd. Doç. Dr. Hüsamettin, “Çanakkale Savaşları’nın Milli Mücadelemize Etkisi”, Atatürk Araştırma Merkezi Dergisi, C.10, S.30 (Kasım 1994), s. 579587.

Öztürk, Hüsamettin "Çanakkale ve Boğaz Bölgesinin İşgali ve Akbaş Olayı”, Tarih Dünyası, S.99 (Mart 1995), s. 5-12.

Öztürk, Hüsamettin, “Çanakkale'deki Komutan İle Modern Türkiye Cumhuriyeti’ne”, Atatürk Araştırma Merkezi Dergisi, C.12, S. 34 (Mart 1996), s. $315-320$

Öztürk, Mustafa, "Çanakkale Muherebelerinde Türk Ordusunun İkmal ve İaşe Durumu”, Askeri Tarih Belgeleri, C.12, S. 22, (Şubat 1987), s.151-162.

Perk, Kadri. “Çanakkale'nin Eski Zamanları Hakkında Bir Tetkik ve Bu Mıntıkada Cereyan Etmiş Bazı İmha Muharebeleri”, Askeri Мecmua, C. 54, S. 100 (Mart 1936) s.123-130.

Perk, Kadri."Çanakkale Savaşları Tarihi (I. Kısım)" Askeri Mecmua, C.57, S.115 (Kânun-ı Evvel 1939) (115 Sayının Tarih Eki)

Perk, Kadri. "Çanakkale Savaşları Tarihi (2. ve 3. Kısım)”, Askeri Mecmua, C. 58,S. 116, (Mart 1940) (116 Sayının Tarih Kısmı)

Peters, Philip. "Australia and the Çanakkale Wars", "ODTÜ 30. Kuruluş Yıldönümü Çanakkale Savaşları'nın Askeri ve Siyasi Yönü” Sempozyumu Bilidirileri, Ankara, Orta Doğu Teknik Üniversitesi, 1987, s.

Petter, Wolfgang, "Die Dardenellen in der Deutschen Weltkriegsstrateige", Çanakkale Savaşları Sebep ve Sonuçları Uluslararası Sempozyumu, Ankara, T.T.K., 1993, s. 125-136.

Philpott, William. "Kitchener and the $29^{\text {th }}$ Division: A Study in Anglo-French Strategic Relations, 1914-1915." Journal of Strategic Studies. S. 16 (1993) s.375-407.

Rehkopf, Ned B. "The Landing at Gallipoli." The Coast Artillery Journal. S. 68 (June 1928) s.475-91; S.69 (July 1928) s.19-35.

Renzie, William. "Great Britain, Russia and the Straits, 1914-1915." Journal of Modern History. S. 42 (1970) s. 1-20.

Rohwer, Jürgen, "The Fight for the Turkish Narrows: Problems of coordintion in coalition Warfare", Çanakkale Savaşları Sebep ve Sonuçları Uluslararası Sempozyumu, Ankara T.T.K., 1993, s. 137-164. 
Runcie, R. A. K. "The God of Battles and the Fight for Faith." Army Quarterly and Defense Journal. S. 119 (1989) s. 153-63.

Sabit (Mirliva). “Çanakkale Harbi'nde İngiliz Sevk ve İdaresi”, Askeri Mecmua, C.50, S.85, (Haziran 1932), s.43-60.

Sabit (Mirliva). “Çanakkale Harbi’nde İngiliz Sevk ve İdaresi”, Askeri Mecmua, C.50, S. 86, (Eylül 1932), s.326-346.

Sadullah, Naci, "Nazmi Kaptan”, Yedigün Dergisi, No. 106.

Safran, Mustafa, "Bir Kahramanın Doğuşu Çanakkale Savaşları ve Sonuçları", Atatürk Araştırma Merkezi Dergisi, C.10, S.30 (Kasım 1994), s.573-577.

Saraç, İbrahim. “18 Mart Deniz Savaşı”, Birlik, C.2, S. 20 (Mart 1986) s. 8-10.

Satıcı, M. Erdoğan. “Çanakkale Zaferi’nde Türk Deniz Kuvvetleri”, Türk Dünyası Tarih Dergisi, C.4, S. 39 (Mart 1990) s. 38-45.

Selçuk, H. Veli, "Çanakkale Nedir ? Çanakkale Zaferinin Sonuçları" Belgelerle Türk Tarihi Dergisi, S. 38 (Mart 2000), s. 17-22.

Sertoğlu, Mithat. "İtilâf Devletlerinin Çanakkale Savaşına Girmelerinin Sebebi", Belgelerle Türk Tarihi Dergisi, C.11, S. 65 (Şubat 1973) s.11-12.

Sertoğlu, Mithat. "Çanakkale Geçilmez”, Kemalizm, C.18, S. 212 (Mart 1980) s. 712.

Sertoğlu, Mithat. "Çanakkale Savaşları ve Zaferi”, Resimli Tarih Mecmuası, C.6, S.71 (1955) s.4115-4200.

Schneide, Karl Stirling. "Aviation in the Dardenelles Campaign : March 1915January 1916” Çanakkale Savaşları, Sebep ve Sonuçları Uluslararası Sempozyumu. Ankara, T.T.K. 1993, s. 91-103.

Skander Bey. "The Tactical Withdrawal by Night: The Lesson of Gallipoli”, Journal of the United Service Institution of India. S.55 (January 1925) s.47-56.

Solak, Mehmet, "İstanbul-Çanakkale Deniz Nakliyatı", Çanakkale Muharebeleri 75 nci Yıl Armağanı, Ankara, Genkur. Bşk., 1990, s. 113-117.

Spiers, Edward. "Gallipoli", The First World War and the British Military History. (Ed. Briand Bond), Oxford, Clarendon Press, 1991.

Stephens, Cortez D. "Gallipoli What Went Right?" Marine Corps Gazette. S. 77 (1993) s.72-77.

Stockwell, A.J., "The War and the British Empire", Britain And The First World War. (Ed. John Turner), London, 1988, s. 36-52.

S,er, Hikmet, "Çanakkale Muharebeleri'nde Türk Pilotu” Çanakkale Muharebelerinin 75 nci Yıl Armağanı, Ankara, Genkur. Bşk., 1990, s.135-140.

Sürvegil, Sabri, “Çanakkale Savaşları ve İzmir", Askeri Tarih Belgeleri, C. 15, S. 28 (Şubat 1990), s.85-103.

Süslü, Azmi, "Çanakkale Savaşları ve Önemi”, Atatürk Araştırma Merkezi Dergisi, C. 7, S. 20 (Mart 1991), s.303-307. 
Süslü, Azmi, "Çanakkale Zaferi ve Atatürk", Atatürk Araștırma Merkezi Dergisi, C.12, S.34 (Mart 1996), s. 283-288.

Şapolyo, Enver Behnan. "Çanakkale Zaferi”, Illler ve Belediyeler Dergisi, C.10, S.114 (Nisan 1955) s.237-240.

Şen, Sabahattin, "Çanakkale'de Savaşan Dominyon Askerlerinden “ANZAK” ların Aldatılışı” Çanakkale Muharebelerinin 75 nci Yıl Armağanı, Ankara, Genkur. Bşk.,1990,s.169-180.

Tanfer, M. Vehbi, "Çanakkale Muharebeleri'nin Tarihimizdeki Yeri ve Önemi”, Atatürk Araştırma Merkezi Dergisi, C.10, S. 30 (Kasım 1994), s. 663-669.

“Tarihi Gerçekler”, Deniz Kuvvetleri Dergisi, C. 76, S. 469 (Nisan 1970) s.53.

Taş, N. Fahri, "Çanakkale Muharebeleri'nin Sebep ve Sonuçları", Askeri Tarih Belgeleri. C.16, S. 30 (Şubat 1991), s. 85-90.

Tekeli, Öğ. Üst̆g. Sadık. "Çanakkale Muharebeleri ve Önemi”, Silahlı Kuvvetler Dergisi, C.108, S. 321 (Mayıs 1989) s.64-70.

Tekinay, M. Reşat. “18 Mart Zaferi”, Kemalizm, C. 7, S. 80 (Mart 1969) s. 11-12.

Tellioğlu, Dr. Saip. "Mustafa Kemal ve Anzaklar”, Türk Kültürü Araştırmalart, C.10, S.109 (Kasım 1971) s. 39-40.

Temiz, Ahmet. "18 Mart 1915”, Yeni Sabah Gazetesi, S. 5054 (1952) s.2-5.

Thomson, Alistar. "History and 'Betrayal'": The Anzac Controversyî History Today. S.43 (1993) s. 8-11

Thomson, Alistair. "Gallipoli--A Past That We Can Live By?" Melbourne Historical Journal. S. 14 (1982) s.56-72.

Till, Geffrey, "Brothers in Arms: The British Army and Navy at the Dardenelles" Facing Armageddon: The First World War Experienced. (Ed. Hugh Cecil and Peter H. Leddle)London, Leo Cooper, 1996.

Timurtaş, Faruk Kadri. "Çanakkale Şehitleri ve Mehmet Akif”, Son Havadis, (22 Mart 1969)

Timurtaş, Faruk Kadri. "Çanakkale İçin Şiirler”, Türk Edebiyatı, C.1, S. 4 (Nisan 1972) s.11-13

Tomazi, A., "Çanakkale Çıkarmasının Hazırlanması (Mart-Nisan 1915)", (Çev., Hüseyin Işık) Askeri Tarih Belgeleri, C.10, S. 18 (Şubat 1985), s. 81-92.

Topuklu, Lütfi. "Türk’ün Dünyada Kabul Ettirdiği Söz: Çanakkale Geçilmez", Kemalizm ve Türkiye, C.2, S.15 (Mart 1977) s. 19.

Travers, T. H. E. "Command and Leadership Styles in the British Army: The 1915 Gallipoli Model” Journal of Contemporary History. S. 29 ( 1994) s. 403-442.

Triton, Romolo. "Dardenelli e Monte Cassino: Erroi Delle due Guerre Mondiali" Rassegna Italiana di Politica e di Culutura. S. 36 (1959) s.376-388.

Trumpener, Ulrich. "Germany and the End of the Ottoman Empire", The Great Powers and The End of the Ottoman Empire. (Ed. Marian Kent) London, George Allen and Unwin, 1984. 
Trumpener, Ulrich. "Liman Von Sanders and the German-Ottoman Alliance" Journal of Contemporary History. S.1 (October 1966) s.179-92.

Trumpener, Ulrich. "German Military Aid to Turkey in 1914: An Historical ReEvalution” Journal of Modern History. S. 32 ( 1960) s.145-149.

Tunay, Mehmet İhsan. "Truva ve Çanakkale Savaşları”, Turizm, C. 13, S. 104 (Ocak 1970) s. 4.

Tunçoku, A. Mete, "Çanakkale Muharebelerinde Bir Rus Krovazörü: Askold”, Çanakkale Muharebeleri 75 nci Yıl Armağanı, Ankara, Genkur. Bşk., 1990, s.119-134.

Tunçoku, A. Mete, "İngiliz Gizli Belgelerinde 18 Mart Zaferi ve Çanakkale Muharebeleri” Çanakkale Muharebeleri 75 nci Yıl Armağanı, Ankara, Genkur. Bşk., 1990, s.29-34.

Tunçoku, Mete. “İsrail'in Kuruluşuna Varan Gelişmeler İçinde Çanakkale Savaşlarının Önemi”, Belleten, S.212 (Nisan 1991) s. 101-108.

Tunçoku, Mete, "Çanakkale Savaşları ve İngiliz-Japon Diplomasisi”, Çanakkale Savaşları Sebep ve Sonuçları Uluslararası Sempozyumu, Ankara, T.T.K., 1993, s.69-84.

Tunçoku, Mete, “Çanakkale'de Hint Birlikleri: Sih, Gurka ve Pencaplı Savaşcıların Öyküsü” Silahlı Kuvvetler Dergisi, C.115, S. 348, (Nisan 1996), s. 9-14 .

Tunçoku, Mete,"Çanakkale Savaşlarının Günümüze Yansıyan Stratejik Sonuçları”, Atatürk Araştırma Merkezi Dergisi, C.14, S. 41 (Temmuz 1988), s. 559-571.

Tunçoku, Mete, "Çanakkale Savaşları ve İrlandalılar", Askeri Tarih Belgeleri, C. 25, S.48 (Şubat 2000), s. 1-16.

Tunçoku, Mete. "Çanakkale Muharebeleri ve Yunan Dış Politikası”, Beşinci Askeri Tarih Semineri Bildirileri I. Değişen Dünya Dengeleri İçinde Askeri ve Stratejik Açıdan Türkiye (23-25 Ekim 1995-İstanbul), Ankara, Genelkurmay Basım Evi, 1996, s.11-20.

Tural, Mehmet Akif, "Kahramanlık Kavramı ve Atatürk'ün Kişiliğinde Bu Kavramın Yeri (Trablusgarp, Çanakkale ve Sakarya'dan İzmir'in Alınışına)”, Atatürk Araştırma Merkezi Dergisi, C. 10, S.30 (Kasım 1994), s. 695-716.

Turan, Refik, "Tarihi Seyir ve Çanakkale Zaferinde Liderler ", Atatürk Araştırma Merkezi Dergisi, C.10, S.30 (Kasım 1994), s. 559-565.

Turan, Refik, "Türk Savaş Motivasyonu ve Çanakkale" Atatürk Araştırma Merkezi Dergisi, C.12 , S. 34 (Mart 1996), s.289-293.

"Turkish General Staff History of the Campaign in Gallipoli", Army Quartrely. S. 11 (1925-26) s.343-53; S.12 (1926) s.88-95.

Turner, John. "Cabinets, Committees and Secretariats: The Higher Direction of the War" War and the State: The Transformation of British Government, 19141919. (Ed. Kathleen Burke). London, George Allen Unvin, 1982 .

Ulrich, Volker. "Entscheidung im Osten Oder sicherung der Dardenellen: Das Ringen um den Serbienfeldzug 1915" Militargeschichfliche Mitteilungen. (1982) s.45-63. 
Uluğ, N. Hakkı. "Çanakkale'de Karşımızda Sanki Alevden Bir Perde Vardı" Hayat. S.18 (Nisan 1972) s.

Ulusoy, Nilay, "Seksen Yıldır Çözülemeyen Sır: Çanakkale'deki Bulut, Uzay Gemisi miydi?” Nokta, C.13, S. 33 (13-19 Ağustos 1995), s. 46-47.

Ülker, Necmi, "Çanakkale Zaferinin İzmir Basınındaki Akisleri”, Atatürk Araştırma Merkezi Dergisi, C.4, S.14 (Kasım 1994), s. 267-278.

Ünal, Mehmet, Ali, "Çanakkale Savaşları ve Sömürgeciliğin Sonu”, Atatürk Araştırma Merkezi Dergisi, C.10, S. 30, (Kasım 1994), s. 567-571.

Ünaydın, Ruşen Eşref. "Çanakkale’yi Tavaf”, 18 Mart 1915-1950, s. 26-28, Ankara, T.T.K. Basımevi, 1950.

Ürekli, Yrd. Doç. Dr. Bayram. "Çanakkale Zaferinin Türk Tarihindeki Önemi” Ata Dergisi, S.1 (1991) s.97-106.

Wallin, Jeffrey. "Politics and Strategy in the Darnelles Operation" Statesmanship: Essays in Honor of Sir Winston Spenser Churchill, (Ed. Harry Jaffa) Durham, Carolina Academic Press, 1981.

Waterson, Duncan Bruce. "Atatürk , Anzac and Australia”, Atatürkçülük ve Modern Türkiye: Uluslararası Konferans-Atatürk and Modern Turkey:International Conference, Ankara, Ankara Üniversitesi Siyasal Bilgiler Fakültesi, 1999, s.689700 .

Watson, S. H. "The Gallipoli Blunder" Army Quarterly and Defense Journal. S.112 (1982) s.178-183.

William, Orlo. "The Gallipoli Tragedy" The Nineteenth Century and After. S.106

(July 1929) s. 82-94.

Winter, Denis. "The Anzac Book: A Re-Appraisal." Journal of the Australian War Memorial.S. 16 (April 1990) s. 58-61.

Winter, Denis. "The Anzac Landing- The Great Gamble?" Journal of the Australian War Memorial. S. 4 (April 1984 ) s. 13-21.

Witheford, Donald W. “Atatürk'ün Avustralyalıların Bakış Açısından Bir Değerlendirmesi“, Atatürk'ün Ölümünün 50. Yılı Sempozyumu, (31 Ekim-1 Kasım 1998), Ankara, 1989 s.39-42.

Wykes, Alan. "Gallipoli”, British History Illustrated . S. 1 (1974) s. 32-39.

Yalçın, Prof. Dr. Süleyman. "Anafartalar Zaferi ve Şehitlerimiz" Tercüman Gazetesi, (Ağustos 1984) s.2.

Yalçıner, Hayri, “18 Mart Çanakkale Zaferi”, Silahlı Kuvvetler Dergisi, C.81-82, S. 204-205 (Aralık 1962- Mart 1963), s. 21-28.

Yılmaz, Önder. "İşte Tarihi Gerçek" Milliyet, (19 Mart 2000) s.17.

Yüksel, Orhan Ş. "50 Yıl Önce Çanakkale Savaşını Kazanmıştık" Hayat Tarih Mecmuast, C.1 S. 2 (Mart 1965) s.4-11. 